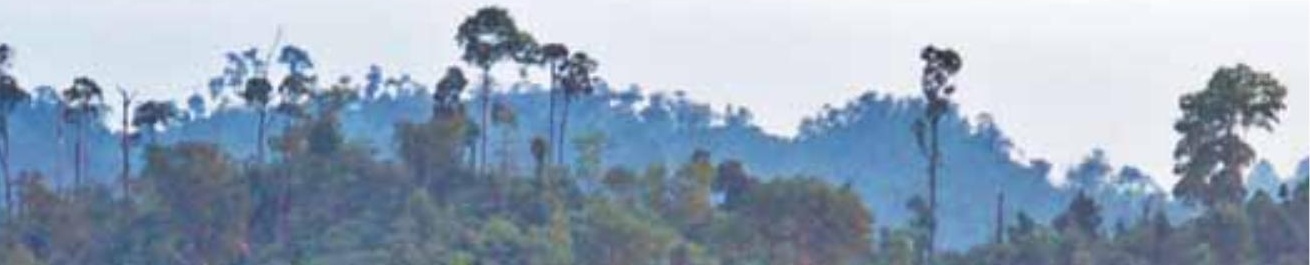

\title{
Panduan Investigasi dan Penuntutan dengan Pendekatan Hukum Terpadu
}

Topo Santoso

Rosalita Chandra

Anna Christina Sinaga

Mumu Muhajir

Sofi Mardiah 



\section{Panduan Investigasi dan Penuntutan dengan Pendekatan Hukum Terpadu}

Topo Santoso

Rosalita Chandra

Anna Christina Sinaga

Mumu Muhajir

Sofi Mardiah 
(c) 2011 Center for International Forestry Research

Hak cipta dilindungi oleh Undang-Undang

ISBN 978-602-8693-45-5

Foto oleh CIFOR/Aulia Erlangga dan Moses Ceaser/Enlight Storyworks

Santoso, T., Chandra, R., Sinaga, A.C., Muhajir, M. dan Mardiah, S. 2011 Panduan investigasi dan penuntutan dengan pendekatan hukum terpadu. CIFOR, Bogor, Indonesia.

\author{
CIFOR \\ Jl. CIFOR, Situ Gede \\ Bogor Barat 16115 \\ Indonesia \\ T +62 (251) 8622-622 \\ $\mathrm{F}+62$ (251) 8622-100 \\ Ecifor@cgiar.org
}

Pandangan yang diungkapkan dalam buku ini berasal dari penulis dan bukan berarti merupakan pandangan dari CIFOR, lembaga asal penulis atau penyandang dana penerbitan buku ini. 


\section{Daftar Isi}

Daftar Singkatan v v

Profil Penulis $\quad$ vi

Ucapan Terima Kasih vii

$\begin{array}{ll}\text { Pengantar viii } & \text { va }\end{array}$

1 Pendahuluan 1

2 Kejahatan di Bidang Kehutanan 5

2.1 Apa yang Mendorong Kerusakan Hutan? 5

2.2 Apa Saja Cakupan Kejahatan di Bidang Kehutanan? 7

2.3 Bagaimana Penanganan Kejahatan di Bidang Kehutanan? 12

3 Pendekatan ILEA dalam Penanganan Kejahatan di Bidang Kehutanan $\quad 17$

$\begin{array}{ll}3.1 \text { Perangkat ILEA } & 17\end{array}$

$\begin{array}{ll}3.2 \text { Komponen ILEA } & 20\end{array}$

3.3 Langkah-Langkah Penanganan Pembalakan Liar dengan Konsep Pendekatan Penegakan Hukum Terpadu (ILEA) 22

4 Tindak Pidana Korupsi dan Pencucian Uang serta Unsur-Unsurnya 27

$\begin{array}{ll}4.1 \text { Tindak Pidana Korupsi } & 27\end{array}$

4.2 Tindak Pidana Pencucian Uang 45

4.3 Pendekatan ILEA Melalui UU Pemberantasan Tindak Pidana Korupsi dan UU Pencegahan dan Pemberantasan Tindak Pidana Pencucian Uang 57

5 Proses Penanganan Perkara $\quad 65$

5.1 Peranan Lembaga Penegak Hukum 65

$\begin{array}{ll}5.2 \text { Prosedur Hukum Acara } & 69\end{array}$

5.3 Masalah Khusus: Pengembalian Aset Hasil Kejahatan 82

6 Penutup $\quad 85$

$\begin{array}{lr}\text { Daftar Pustaka } & 87\end{array}$

$\begin{array}{ll}\text { Lampiran 1. Peraturan Perundang-undangan } & 90\end{array}$ 


\section{Daftar Tabel, Gambar dan Kotak}

\section{Tabel}

1 Klasifikasi Pelaku Perusakan Hutan Berdasarkan Peranan 6

2 Klasifikasi Kelompok Pengusaha Sektor Kehutanan Berdasarkan Perizinan $\quad 7$

3 Jenis Kejahatan di Bidang Kehutanan Berdasarkan UU No. 41 Tahun 1999 tentang Kehutanan 8

4 Jenis Pelanggaran di Bidang Kehutanan Berdasarkan UU No. 41 Tahun 1999 $\begin{array}{ll}\text { tentang Kehutanan } & 11\end{array}$

5 Langkah-Langkah Penegakan Hukum dalam Konsep ILEA 24

6 Contoh Perkara Tindak Pidana Korupsi dalam Kejahatan di Bidang Kehutanan 29

7 Contoh Perkara Tindak Pidana Pencucian Uang dalam Kejahatan di Bidang Kehutanan 53

8 Jenis-Jenis Kejahatan Bidang Kehutanan Melalui Pendekatan UU Pemberantasan Tindak Pidana Korupsi dan UU Pencegahan dan Pemberantasan Tindak Pidana Pencucian Uang

\section{Gambar}

1 Alur Penanganan Kejahatan di Bidang Kehutanan Berdasarkan UU No. 41 Tahun 1999

2 Model ILEA

3 Unsur-Unsur Pokok Pencucian Uang

4 Ilustrasi Pendanaan Pembalakan Liar

5 Contoh Kasus Ilustrasi Aliran Uang dari Pembalakan Liar

6 Arus Mutasi Rekening

7 Alur Kejahatan Bidang Kehutanan dengan Pendekatan Tindak Pidana Korupsi dan Tindak Pidana Pencucian Uang (Berdasarkan Pelaku dan Modus Operandi)

\section{Kotak}

1 Unsur-Unsur Tindak Pidana Korupsi dalam Pasal 2 UU No. 31 Tahun 1999 jo UU No. 20 Tahun 2001

2 Unsur-Unsur Tindak Pidana Korupsi dalam Pasal 3 UU No. 31 Tahun 1999 jo UU No. 20 Tahun 2001

3 Unsur-Unsur Tindak Pidana Korupsi dalam Pasal 5 ayat (1) a UU No. 31 Tahun 1999 jo UU No. 20 Tahun 2001

4 Unsur-Unsur Tindak Pidana Pencucian Uang dalam Pasal 3 UU No. 8 Tahun 2010

5 Unsur-Unsur Tindak Pidana Pencucian Uang dalam Pasal 5 UU No. 8 Tahun 2010 


\section{Daftar Singkatan}

$\begin{array}{ll}\text { BPK } & \text { Badan Pemeriksa Keuangan } \\ \text { DPR } & \text { Dewan Perwakilan Rakyat } \\ \text { DPRD } & \text { Dewan Perwakilan Rakyat Daerah } \\ \text { FGD } & \text { Focus group discussion } \\ \text { HPH } & \text { Hak Pengusahaan Hutan } \\ \text { HPHTI } & \text { Hak Pengusahaan Hutan Tanaman Industri } \\ \text { ILEA } & \text { Integrated Law Enforcement Approach (Pendekatan Penegakan } \\ & \text { Hukum Terpadu) } \\ \text { JPU } & \text { Jaksa Penuntut Umum } \\ \text { KKN } & \text { Korupsi, kolusi, dan nepotisme } \\ \text { KPK } & \text { Komisi Pemberantasan Korupsi } \\ \text { KUHP } & \text { Kitab Undang-Undang Hukum Pidana } \\ \text { KUHAP } & \text { Kitab Undang-Undang Hukum Acara Pidana } \\ \text { MLA } & \text { Mutual legal assistance (Bantuan Hukum Timbal Balik) } \\ \text { NGO } & \text { Nongovermental organisation } \\ \text { PNS } & \text { Pegawai Negeri Sipil } \\ \text { PPNS } & \text { Penyidik Pegawai Negeri Sipil } \\ \text { Polri } & \text { Kepolisian Negara Republik Indonesia } \\ \text { PPATK } & \text { Pusat Pelaporan dan Analisis Transaksi Keuangan } \\ \text { RUU } & \text { Rancangan Undang-Undang } \\ \text { SKSHH } & \text { Surat Keterangan Sah Hasil Hutan } \\ \text { TNI } & \text { Tentara Nasional Indonesia } \\ \text { TPI } & \text { Tebang Pilih Indonesia } \\ \text { UU } & \text { Undang-Undang }\end{array}$




\section{Profil Penulis}

Topo Santoso adalah dosen tetap di Fakultas Hukum Universitas Indonesia (FH-UI) dan Direktur Djokosoetono Reserch Center di FH-UI. Hingga saat ini dia telah mengajar beberapa mata kuliah antara lain: Hukum Pidana, Sejarah dan Perbandingan Hukum Pidana, Tindak Pidana Tertentu dalam KUHP, Tindak Pidana Ekonomi dan Anti Korupsi serta Kriminologi. Dia menyelesaian pendidikan sarjana hukum tahun 1992 (UI), magister hukum tahun 2000 (UI), dan PhD tahun 2009 di University of Malaya. Sampai saat ini Topo sudah menghasilkan 17 buku, ratusan artikel di berbagai jurnal ilmiah dan media massa nasional serta aktif menjadi narasumber dalam berbagai seminar, lokakarya dan kegiatan ilmiah lainnya.

Rosalita Chandra menyelesaikan pendidikan sarjana hukum dan magister program hukum ekonomi di FH-UI. Ia memulai karirnya sebagai peneliti sejak 2002 pada Pusat Studi Peradilan Pidana Indonesia (PSPPI) serta Perkumpulan untuk Pemilu dan Demokrasi (Perludem). Selain itu dia aktif pula menjalankan profesi sebagai advokat, konsultan hukum dan kurator kepailitan pada Azalea Law Office. Saat ini Rosalita juga mengabdi sebagai dosen di berbagai universitas untuk mata kuliah hukum pidana, tindak pidana ekonomi dan hukum perlindungan konsumen.

Anna Christina Sinaga adalah peneliti di Program Forests and Governance di CIFOR sejak tahun 2007. Dia menyelesaikan sarjana hukum di FH-UI tahun 2003 dan meraih gelar magister hukum di Fakultas Hukum Universiteit Utrecht tahun 2005. Fokus penelitiannya mencakup perancangan peraturan perundang-undangan (legal drafting), penegakan hukum, korupsi dan kehutanan, dan peran perbankan dalam upaya penegakan hukum di sektor kehutanan.

Mumu Muhajir adalah manajer program untuk hukum dan keadilan lingkungan pada Epistema Institute. Sebelumnya, dia adalah peneliti hukum sumberdaya alam di GreenLaw (2006) dan IHSA (2006 - 2007). Mumu mendapatkan gelar sarjana hukum dari Universitas Gadjah Mada. Selain aktif melakukan kajian aspek hukum dan masyarakat dalam pengelolaan sumberdaya alam dan isu-isu lingkungan hidup, ia juga aktif dalam kegiatan lobi dan advokasi kebijakan.

Sofi Mardiah adalah asisten peneliti di Program Forests and Governance di CIFOR sejak tahun 2007. Dia menyelesaikan pendidikan sarjana kehutanan di Fakultas Kehutanan Institut Pertanian Bogor tahun 2002 dan meraih gelar magister sains di Sekolah Pasca Sarjana pada Program Studi Ilmu Pengelolaan Sumberdaya Alam dan Lingkungan Institut Pertanian tahun 2006. Di CIFOR, fokus penelitiannya mencakup analisis keuangan di sektor kehutanan, peran perbankan dalam upaya penegakan hukum sektor kehutanan, dan korupsi dan kehutanan. 


\section{Ucapan Terima Kasih}

Penulisan panduan bisa terlaksana berkat semangat dan keterlibatan banyak pihak. Kami mengucapkan terima kasih kepada Komisi Pemberantasan Korupsi (KPK), Pusat Pelaporan dan Analisis Transaksi Keuangan (PPATK) dan Badan Pemeriksa Keuangan (BPK) yang telah membagi pengalaman dan memberi masukan sejak awal buku panduan ini ditulis sampai tahap penyelesaiannya.

Kami juga berterima kasih kepada Dr. Yenti Genarsih, SH.MH dari Fakultas Hukum Universitas Trisakti, Prof. Dr. Eddy O.S. Hiariej, SH., MH dari Fakultas Hukum Universitas Gadjahmada, Prof. Dr. Edi Setiadi, SH, Fakultas Hukum Universitas Islam Bandung (UNISBA), Dr. Bambang Prabowo S, Deni Bram, SH., MH dan Dr. Surastini Fitriasih, SH., MH dari Fakultas Hukum Universitas Indonesia, Erlin, SH., MH dari Kejaksaan Negeri Sleman dan Edy Wibisono SH., SE dari Pengadilan Negeri Cibinong yang telah membagi pengalaman dan memberi masukan pada Focus Group Discussion untuk penyempurnaan naskah panduan ini.

Terima kasih juga kami sampaikan kepada para partner kami Jaringan Kerja Penyelamat Hutan Riau (Jikalahari) dan Institut Hukum dan Sumber Daya Alam (IHSA) Kalimantan Timur yang telah memberikan kontribusi yang sangat berarti dalam mendukung pengembangan konsep Integrated Law Enforcement Approach (ILEA).

Ucapan terima kasih juga kami tujukan kepada Dr. Bambang Setiono dalam keterlibatannya pada studi ini.

Kami menyadari bahwa perjuangan untuk melawan pembalakan liar, korupsi dan pencucian uang masih panjang. Kami berharap bahwa adanya panduan ini bisa memberi semangat baru bagi para pihak terkait untuk terus bekerja dan membenahi benang kusut dalam penegakan hukum terkait kejahatan kehutanan, korupsi dan pencucian uang di Indonesia.

Panduan ini dapat diterbitkan dengan dukungan dana dari Kementerian Luar Negeri, Pemerintah Norwegia. 


\section{Pengantar}

Pembalakan liar adalah kejahatan multidimensional. Kejahatan ini tidak hanya melanggar Undang-Undang (UU) Kehutanan semata tetapi juga UU Pemberantasan Tindak Pidana Korupsi, UU Pencegahan dan Pemberantasan Tindak Pidana Pencucian Uang, bahkan juga UU Lingkungan Hidup dan UU Kepabeanan. Rumitnya jaringan dan luasnya lingkup pelaku tindak pidana ini memerlukan suatu pendekatan penegakan hukum yang lebih terpadu, terintegrasi dan komprehensif. Pendekatan yang demikianlah yang hendak diperkenalkan dan didiskusikan dalam buku ini.

Penerbitan buku Panduan Penyelidikan dan Penuntutan dengan Pendekatan Hukum Terpadu ini dimaksudkan sebagai bagian dari upaya untuk mendorong suatu keterpaduan penegakan hukum atas kasus-kasus kejahatan di bidang kehutanan. Oleh karena itu uraian dalam buku panduan ini berpusat pada kejahatan di bidang kehutanan, kejahatan korupsi di sektor kehutanan dan kejahatan pencucian uang dari kejahatan kehutanan.

Buku panduan ini merupakan suatu sarana yang tidak mengikat (non-binding tool) yang bisa disebarluaskan dan digunakan untuk membantu penegak hukum di Indonesia dalam menangani kasus-kasus tindak pidana di bidang kehutanan dengan pendekatan yang lebih komprehensif. Karena itu buku ini ditulis terutama untuk lembaga penegak hukum diantaranya adalah Penyidik Pegawai Negeri Sipil (PPNS) Kehutanan, Kepolisian, Kejaksaan, Komisi Pemberantasan Korupsi (KPK) dan Hakim namun juga tidak tertutup untuk pemangku kepentingan lainnya seperti LSM dan masyarakat. Melalui buku panduan ini berbagai pihak penegak hukum diharapkan mempunyai pandangan yang lebih luas dan sarana bantu untuk menangani permasalahan hukum pidana yang menyangkut kasus-kasus kehutanan.

Buku panduan ini ditulis berdasarkan pengembangan konsep ILEA dari CIFOR. Serangkaian kegiatan diskusi baik informal dan formal (melalui Focus Group Discussion - FGD) telah dilakukan selama kurun waktu 2009 - 2011 untuk menyempurnakan buku panduan ini. Diskusi-diskusi tersebut dilakukan dengan melibatkan para ahli di bidang hukum pidana, tindak pidana korupsi, lingkungan, dan pencucian uang serta kalangan lembaga swadaya masyarakat dan penegak hukum. 
Penggunaan perangkat anti korupsi dan anti pencucian uang di sektor kehutanan memang masih baru. Karena itu, diharapkan dengan buku panduan ini penegak hukum dapat memilah apakah sebuah kasus hanya berkaitan dengan kejahatan kehutanan, ataukah juga berkaitan dengan kejahatan korupsi dan pencucian uang. Namun mengingat sifat buku ini yang singkat dan padat, diharapkan para pengguna buku panduan ini untuk tetap melengkapinya dengan berbagai peraturan perundangundangan di bidang kehutanan, korupsi dan pencucian uang serta sumber-sumber lainnya yang terkait.

Dengan berbagai keterbatasannya buku panduan ini diharapkan bermanfaat baik bagi penegak hukum maupun pihak-pihak lainnya yang berkaitan dengan penegakan hukum di sektor kehutanan serta pihak-pihak yang menaruh perhatian di bidang ini. 



\section{1}

\section{Pendahuluan}

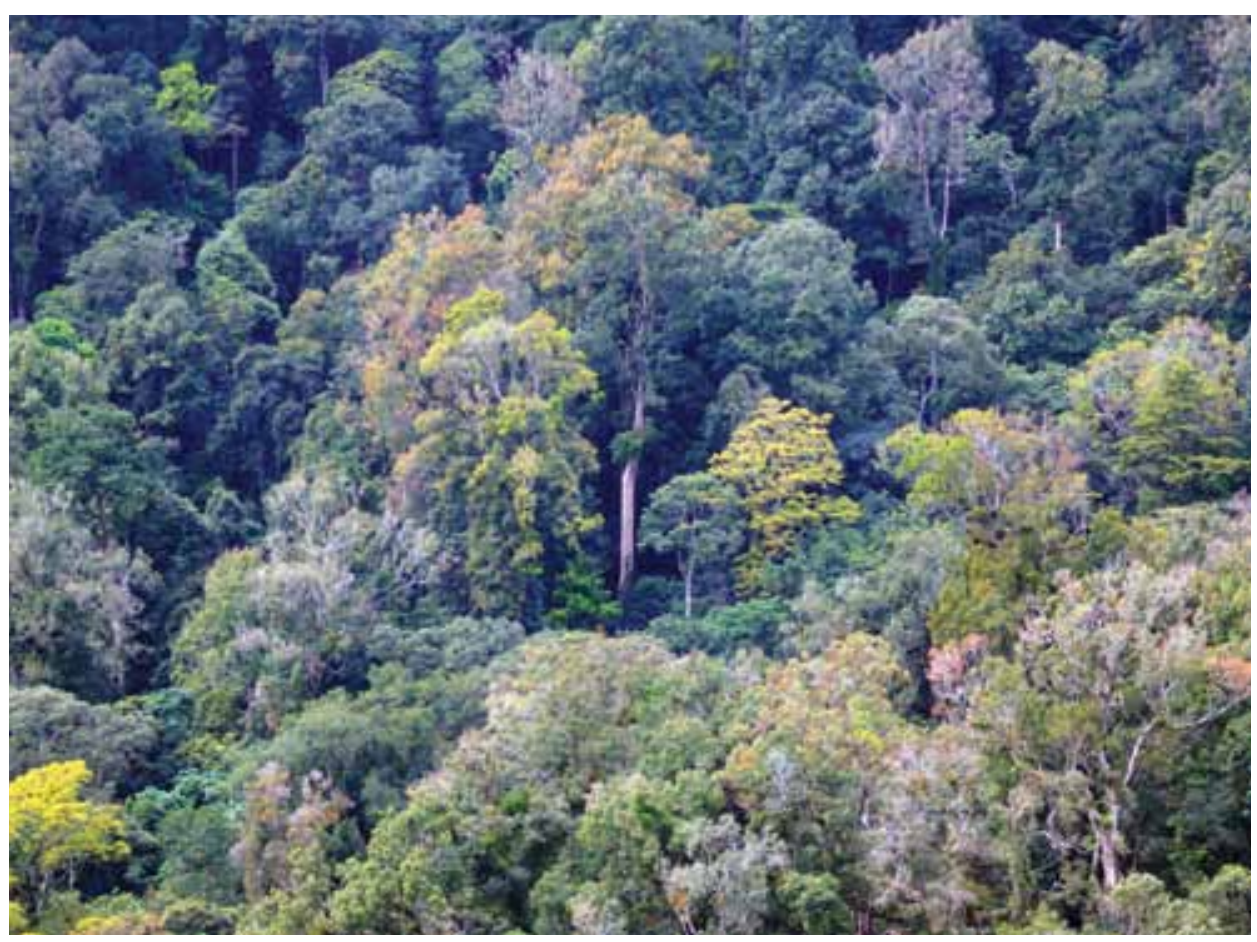

Desakan terhadap penegakan hukum kejahatan kehutanan mulai terjadi ketika laju deforestasi terhadap hutan di Indonesia terus menunjukkan angka kenaikan yang signifikan. Tercatat, antara tahun 1970-an dan 1990-an, laju deforestasi diperkirakan antara 0,6 dan 1,2 juta ha (Sunderlin dan Resosudarmo 1996). Laju ini kemudian meningkat menjadi sekitar 1,7 juta Hektar pertahun pada tahun 1985-1997 (FWI/ GFW 2001). Data terakhir yang dirilis oleh Kementerian Negara Lingkungan Hidup berdasarkan Laporan Status Lingkungan Hidup Indonesia tahun 2006 menyebutkan angka laju deforestasi mencapai 1,19 juta hektar per tahun (Menlh 2006). Pembalakan liar telah dianggap menjadi salah satu penyebab terbesar deforestasi. Laporan Telapak misalnya menyebutkan bahwa angka penjarahan kayu lewat pembalakan liar di Indonesia mencapai $80 \%$ dari total tebangan kayu (Tacconi dkk. 2004). 
Salah satu upaya yang dilakukan pemerintah untuk memberantas pembalakan liar adalah menggelar serangkaian operasi penegakan hukum di lapangan. Selama tahun 2004-2006 Pemerintah menggelar Operasi Hutan Lestari (OHL) di Papua, Kalimantan dan Sumatra. Dari OHL II yang dilakukan tahun 2005 di Papua misalnya, pihak kepolisian telah memproses 116 perkara pembalakan liar. Meski demikian, jumlah putusan pengadilan mengenai tindak pidana kehutanan tidak banyak. Dalam prosesnya, kasus demi kasus pembalakan liar berguguran baik di tingkat penyelidikan, penyidikan, maupun di pengadilan. Hal ini terlihat dari 116 kasus hasil OHL II yang diproses, hanya 88 perkara berlanjut ke kejaksaan. Sementara penyidikan terhadap 17 perkara sisanya dihentikan karena kurang bukti. Lebih lanjut, dari 88 perkara tersebut, hanya sebanyak 27 perkara kemudian berlanjut ke pengadilan, 13 perkara selesai dengan vonis 7 bulan hingga 2 tahun dan 14 perkara lainnya divonis bebas (ICW 2009).

Selain minimnya putusan bersalah terhadap pelaku kejahatan kehutanan, hasil penelitian Indonesian Corruption Watch (ICW) di tahun 2009 juga menunjukkan bahwa para pelaku kejahatan kehutanan yang diputus bersalah oleh hakim, umumnya merupakan pelaku lapangan (misalnya, supir pengangkut kayu illegal, mandor, pemanen kayu). Hal ini menunjukkan bahwa para cukong, pemegang modal, pejabat yang terlibat, serta aktor intelektual dari kasus-kasus itu tidak terungkap, apalagi dihukum (ICW 2009).

Bebasnya aktor-aktor kejahatan kehutanan tentunya menimbulkan berbagai pertanyaan seperti, apakah hakimnya memang salah dalam mengambil keputusan? Apakah kelemahan itu terletak pada surat dakwaan dan tuntutan pidananya? Apakah surat dakwaan sudah sejak awal lemah yakni sejak dari proses penyelidikan dan penyidikannya? Ataukah hal ini disebabkan oleh peran serta masyarakat yang kurang karena takut menjadi saksi?

Lebih lanjut, lemahnya perlindungan hutan dari sisi penegakan hukum antara lain disebabkan oleh praktek yang hanya menggunakan salah satu undang-undang, misalnya UU No. 41 Tahun 1999 tentang Kehutanan, untuk kasus yang kejahatan utamanya illegal logging. Mengapa disebut lemah? Salah satu sebabnya adalah argumen bahwa sudah memiliki ijin menjadi alasan kuat untuk lolos dari jeratan UU No. 41 Tahun1999. Dengan kata lain aspek administratif menjadi peluang untuk menutupi penyimpangan yang ada (yang dikedepankan hanyalah aspek formal belaka). Padahal dalam perkara pidana yang diutamakan adalah kebenaran materil, apalagi potensi penyimpangan dalam hal keluarnya ijin itu sendiri cukup besar. Beberapa modus dari 'mafia kehutanan' antara lain: penyalahgunaan kewenangan dalam penerbitan izin, pemberian izin tidak sesuai peruntukan, regulasi dan kebijakan digunakan untuk menghancurkan hutan dan menutupi kejahatan kehutanan, suap dan gratifikasi terhadap pejabat pusat atau daerah atas izin yang diterbitkan, perusahaan memfasilitasi institusi penegak hukum seperti mobil dinas dan lainnya, pejabat diberi saham gratis di perusahaan, memecah perusahaan untuk mendapat izin lokasi melebihi batas minimum, dan sebagainya (Antasari, 22 April 2010). Kasus yang bisa menggambarkan dengan jelas potensi penyimpangan ini adalah kasus Tengku Azmun Jaafar yang diputus bersalah melakukan tindak pidana korupsi dalam pemberian IUPHHK-HT 
terhadap 15 perusahaan di Kabupaten Pelalawan, Provinsi Riau. ${ }^{1}$ Lebih lanjut, putusan Mahkamah Agung terhadap kasus Adelin Lis juga merupakan bukti lainnya bahwa dibutuhkan perangkat hukum di luar UU No. 41 Tahun 1999 untuk menjerat para pelaku perusakan hutan yang sudah memiliki ijin secara formal. ${ }^{2}$

Berangkat dari kondisi tersebut maka diperlukan suatu pendekatan penegakan hukum yang lebih terpadu, terintegrasi dan komprehensif. Hal ini dimaksudkan untuk bisa 'mengeroyok' tindak pidana bidang kehutanan sehingga mendapatkan hasil yang lebih baik untuk melindungi sektor kehutanan kita. Untuk itu dibutuhkan pendekatan yang tidak hanya bertumpu pada kerangka hukum dan proses penegakan hukum tindak pidana di sektor kehutanan saja namun juga menggunakan kerangka hukum pidana lainnya, seperti anti korupsi dan, bahkan lebih jauh, anti pencucian uang. Dengan penggunaan UU Pemberantasan Tindak Pidana Korupsi, maka beberapa perbuatan yang berkaitan dengan pembalakan liar (illegal logging) dan bisa dimasukkan ke dalam rumusan atau unsur-unsur tindak pidana korupsi dapat dijerat dengan menggunakan UU Pemberantasan Tindak Pidana Korupsi. Perluasan alat-alat bukti dan pembuktian (termasuk pembuktian terbalik terbatas) serta teknik-teknik investigasi yang dimiliki penegak hukum bidang korupsi dapat lebih efektif digunakan karena dalam beberapa kasus kejahatan kehutanan yang dilakukan dimulai dengan adanya beberapa bentuk korupsi.

Begitu pula dengan penggunaan UU Pencegahan dan Pemberantasan Tindak Pidana Pencucian Uang. Kerangka hukum pidana ini juga sangat penting karena prinsipnya adalah 'follow the money' yang tujuannya menelusuri asal usul uang yang dicurigai terkait dengan kejahatan, yang dalam hal ini kejahatan kehutanan. Bahkan, kerangka hukum mengenai pencucian uang juga mengatur proses beracara khusus, alat-alat bukti, dan teknik-teknik penelusuran asal uang hasil kejahatan sehingga diharapkan dapat menguak hasil kejahatannya. Lebih lanjut dalam kerangka hukum anti pencucian uang, untuk dapat melakukan penyidikan, penuntutan dan pemeriksaan di siding pengadilan, tidak wajib dibuktikan dulu kejahatan asalnya (predicate crime) (UU No. 8 Tahun 2010). ${ }^{3}$

Upaya penggunaan perangkat anti korupsi dan anti pencucian uang di sektor kehutanan masih baru. Bahkan ada yang menganggap, penggunaan kedua perangkat hukum tersebut akan membuat penanganan tindak pidana di sektor kehutanan menjadi tidak fokus dan berakibat pada lemahnya penyidikan dan penuntutan di pengadilan. Akan tetapi sebenarnya penegak hukum dapat memilah apakah sebuah kasus hanya berkaitan dengan kejahatan kehutanan, ataukah juga berkaitan dengan kejahatan korupsi dan pencucian uang.

1 Kasus ini diputus oleh Pengadilan Tindak Pidana Korupsi melalui Putusan Nomor: 6/PID/ TPK/2008/PN.JKT.PST.

2 Adelin Lis diputus bersalah melakukan tindak pidana korupsi oleh Mahkamah Agung melalui Putusan No. 68 K/PID.SUS/2008.

3 Semua referensi perundang-undangan bisa dilihat di Lampiran 1. 
Pendapat lain yang berkembang adalah mengenai penerapan asas lex specialis derogat legi generali di dalam penggunaan perangkat hukum anti korupsi dan anti pencucian uang di sektor kehutanan. Pendapat ini beranggapan bahwa perangkat hukum kehutanan adalah hukum yang lebih khusus dari pada perangkat hukum anti korupsi. Sehingga di dalam menangani kasus-kasus tindak pidana di sektor kehutanan cukup menggunakan perangkat hukum sektor kehutanan. Terhadap pendapat ini sesungguhnya yang penting diperhatikan adalah kesiapan aparat birokrasi kehutanan dan aparat penegakan hukum dari berbagai institusi yang berbeda dapat bekerja sama. Tujuannya adalah untuk menganalisis ketentuan yang paling tepat untuk diterapkan (apakah hanya satu ketentuan atau lebih) dan jenis dakwaan yang tepat untuk digunakan (apakah akan didakwa secara tunggal, alternatif, subsidiar berlapis ataukah kumulatif).

Kedua pendapat tersebut di atas, hanyalah sebagian dari masalah yang akan ditemui dalam penerapan pendekatan penegakan hukum terpadu dalam menangani tindak pidana di sektor kehutanan. Namun, dalam prakteknya, permasalahan tersebut sebenarnya dapat diatasi. Misalnya, dalam penentuan jenis dakwaan. Dalam prakteknya, keempat bentuk dakwaan itu ternyata dapat digunakan. Hal ini dapat dilihat sebagai contoh positif yang menunjukkan bahwa pendekatan terpadu dapat digunakan di masa depan.

Dengan demikian menjadi jelas, bahwa pendekatan penegakan hukum atas kasus-kasus kejahatan di bidang kehutanan perlu dilakukan secara komprehensif dan tidak parsial. Diperlukan pendekatan komprehensif yang lebih mampu melindungi sektor kehutanan kita dari kerusakan yang semakin parah. Buku panduan ini berusaha memberikan pendekatan yang lebih komprehensif tersebut. 


\section{Kejahatan di Bidang Kehutanan}

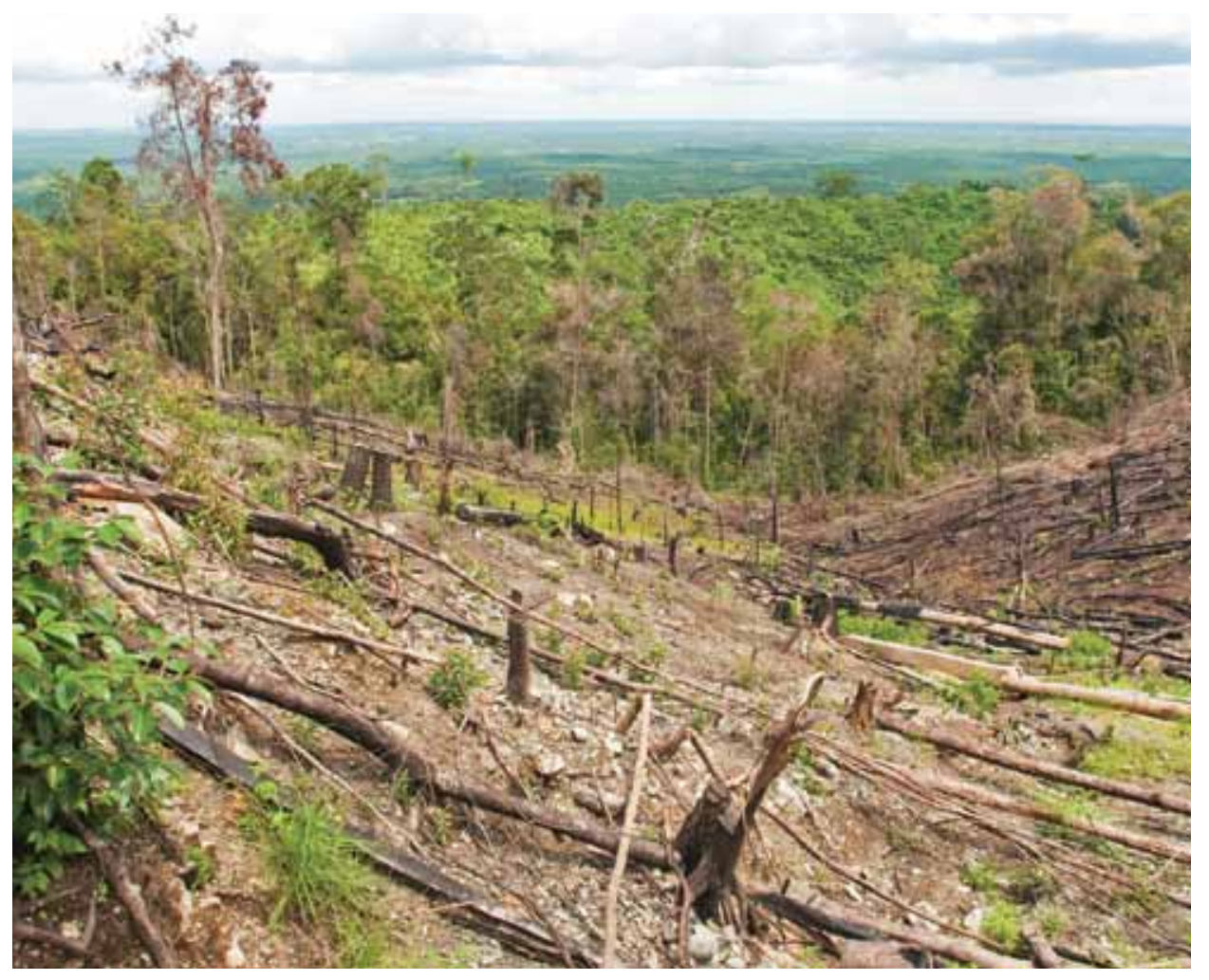

Bab ini secara ringkas menguraikan tentang kejahatan kehutanan berlandaskan Undang-Undang (UU) No. 41 Tahun 1999 tentang Kehutanan. Pembahasannya diawali dengan paparan persoalan kerusakan hutan dan kategori penyimpangannya, disertai pihak-pihak yang terlibat dalam praktik kejahatan di bidang kehutanan dan peranan mereka masing-masing. Bagian selanjutnya membahas pendekatan yang umum digunakan dalam menangani pembalakan liar, yaitu berlandaskan UU Kehutanan. Penggunaan UU lainnya yang berkaitan erat dengan bidang kehutanan (seperti korupsi dan pencucian uang) akan dibahas pada bab-bab selanjutnya.

\subsection{Apa yang Mendorong Kerusakan Hutan?}

Beberapa faktor pendorong kerusakan hutan (Suarga 2005) di antaranya adalah:

1. krisis ekonomi,

2. perubahan tatanan politik,

3. lemahnya koordinasi antaraparat penegak hukum,

4. adanya kolusi, korupsi dan nepotisme,

5. lemahnya sistem pengamanan hutan dan pengamanan hasil hutan, dan

6. harga kayu hasil tebangan liar yang lebih murah. 
Berdasarkan peranannya, para pelaku perusakan hutan dapat diklasifikasikan dalam Tabel 1 (Nurdjana dkk. 2005) sebagai berikut:

Tabel 1. Klasifikasi Pelaku Perusakan Hutan Berdasarkan Peranan

\begin{tabular}{|c|c|}
\hline Pelaku & Peranan \\
\hline $\begin{array}{l}\text { Masyarakat setempat dan masyarakat } \\
\text { pendatang }\end{array}$ & $\begin{array}{l}\text { Melakukan kegiatan penebangan secara } \\
\text { langsung, baik untuk kepentingan sendiri } \\
\text { maupun untuk dijual kepada pengusaha kayu } \\
\text { atau pemilik modal (cukong). }\end{array}$ \\
\hline Pemilik modal dan pengusaha & $\begin{array}{l}\text { Sebagai fasilitator }{ }^{4} \text { atau penadah }{ }^{5} \text { hasil kayu } \\
\text { curian, termasuk menjadi otak pencurian kayu. }\end{array}$ \\
\hline $\begin{array}{l}\text { Pemilik industri kayu atau pemilik } \\
\mathrm{HPH}\end{array}$ & $\begin{array}{l}\text { Sebagai pencuri kayu maupun penadah hasil } \\
\text { kayu curian. }\end{array}$ \\
\hline Nahkoda kapal ${ }^{6}$ & $\begin{array}{l}\text { Turut melakukan atau membantu melakukan } \\
\text { penyelundupan kayu atau pembalakan liar. }\end{array}$ \\
\hline $\begin{array}{l}\text { Oknum pejabat pemerintah dan } \\
\text { oknum aparat pemerintah (oknum } \\
\text { TNI/Polri, Jagawana/PNS Kehutanan, } \\
\text { PNS Bea Cukai, oknum pemerintah } \\
\text { daerah/anggota DPRD/politisi) }\end{array}$ & $\begin{array}{l}\text { Terlibat dalam KKN (korupsi, kolusi, dan } \\
\text { nepotisme) dengan pengusaha atau } \\
\text { manipulasi kebijakan dalam pengelolaan } \\
\text { hutan atau pemberian konsesi penebangan } \\
\text { yang dapat menimbulkan kerusakan hutan. }\end{array}$ \\
\hline Pengusaha asing & $\begin{array}{l}\text { Sebagai pembeli kayu maupun penadah hasil } \\
\text { kayu curian. Terkait dengan kasus pencucian } \\
\text { uang, ditemukan juga modus berupa } \\
\text { pengusaha asing sebagai otak pencurian } \\
\text { kayu, dengan menggunakan orang Indonesia } \\
\text { lokal yang bertindak seakan-akan sebagai } \\
\text { pengusaha kayu. }\end{array}$ \\
\hline
\end{tabular}

Sumber: Nurdjana dkk. (2005) dan Husein (2007)

Di sektor kehutanan, pengusaha yang memanfaatkan kayu sebagai bisnis intinya ada beberapa kelompok (Suarga 2005) yaitu:

1. Hak Pengusahaan Hutan (HPH)

2. Industri kayu (woodwork)

3. Industri kayu lapis (plywood)

4. Industri mebel (furniture)

5. Pertukangan atau kerajinan

4 Dalam hukum pidana materil peranan ini dapat dikaitkan dengan penggerakan/pembujukan untuk melakukan tindak pidana (misalnya, dengan memberikan atau menjanjikan sesuatu, atau dengan memberikan keterangan, sarana, kesempatan) kepada pihak lainnya agar pihak lain ini melakukan kejahatan di bidang kehutanan.

5 Dalam hukum pidana umum sebagaimana diatur di dalam pasal 55-57 KUHP, penadah tidak merupakan bagian dari ketentuan mengenai 'Penyertaan' tetapi menjadi tindak pidana tersendiri di dalam pasal-pasal tertentu (pasal 480 KUHP). Bedanya dengan 'Penyertaan', penadahan dilakukan setelah suatu tindak pidana terjadi, misalnya setelah seseorang mencuri, hasil curiannya dibeli oleh penadah hasil curian tersebut.

6 Keterlibatan nahkoda kapan dalam kasus-kasus pembalakan liar merupakan contoh bahwa proses ini memerlukan pihak-pihak tertentu yang bergerak di sektor perhubungan. 
6. Hak Pengusahaan Hutan Tanaman Industri

7. Industri bubur kayu ( $p u l p)$ dan kertas

Selain itu, khusus dalam tahap investigasi awal kasus kejahatan di bidang kehutanan, kelompok usaha kehutanan dapat dibagi menjadi kelompok HPH/HPHTI dan kelompok industri. Selanjutnya, berdasarkan kepemilikan ijin, pengusaha kehutanan juga dapat dikelompokkan menjadi tiga, seperti dijelaskan dalam Tabel 2.

Tabel 2. Klasifikasi Kelompok Pengusaha Sektor Kehutanan Berdasarkan Perizinan ${ }^{7}$

\begin{tabular}{ll}
\hline Klasifikasi & Keterangan \\
\hline Pengusaha putih & Memiliki izin resmi, baik untuk kelompok HPH/HPHTI maupun \\
& kelompok industri. Batasan yang dapat diukur, antara lain luas \\
& area yang ditebang per tahun sebesar 600.000 ha berdasarkan \\
& Rencana Karya Tahunan 20 juta $\mathrm{m}^{3}$ dan total kapasitas \\
& terpasang industri plywood sebesar 10 juta $\mathrm{m}^{3}$ per tahun. \\
& Dengan mengacu pada izin pemerintah, areal kerja resmi \\
& berdasarkan peta kerja Rencana Umum Tata Ruang, Rencana \\
& Tata Ruang Wilayah Propinsi dan Rencana Tata Ruang Wilayah \\
& Kabupaten, maka keberadaan usaha sektor kehutanan selama \\
& belum direvisi masih sah menurut hukum. \\
\hline Pengusaha abu-abu & Memiliki izin usaha yang didapat setelah Orde Baru dan \\
& setelah pelaksanaan otonomi daerah, yang secara yuridis \\
& berlaku apabila bebas dari pertikaian atau tumpang tindih \\
& kewenangan. Namun kenyataannya, peraturan yang lahir \\
& selama masa reformasi banyak yang memiliki tumpang tindih \\
& kewenangan sehingaa dipandang lemah, sewaktu-waktu dapat \\
& dianulir atau diajukan judicial review. \\
\hline Murni melakukan kegiatan melawan hukum atau tindak pidana \\
seperti penebangan di hutan lindung, penyerobotan kawasan, \\
pencurian kayu dan pemalsuan dokumen.
\end{tabular}

Sumber: Suarga (2005)

Upaya eksplorasi dan eksploitasi kawasan hutan akan berdampak pada kerusakan hutan karena terjadinya perubahan fisik, sifat fisik atau hayatinya, yang menganggu atau merusak fungsi hutan sebagai suatu ekosistem. Perbuatan pelaku eksplorasi dan eksploitasi kawasan hutan yang menyebabkan kerusakan hutan dapat dikategorikan sebagai kejahatan di bidang kehutanan.

\subsection{Apa Saja Cakupan Kejahatan di Bidang Kehutanan?}

Berdasarkan Pasal 78 ayat (13) UU Kehutanan, terdapat beberapa perbuatan yang diklasifikasikan sebagai kejahatan atau tindak pidana di bidang kehutanan. Berbagai kegiatan yang termasuk dalam perbuatan kejahatan dan pelanggaran bidang kehutanan dicantumkan dalam Tabel 3.

7 Istilah-istilah yang digunakan di sini bukan istilah yuridis tetapi istilah secara sosiologis, yang difahami di kalangan yang terlibat dalam persoalan kejahatan di bidang kehutanan. Meski bukan istilah yuridis, kategori sosiologis ini tetap penting untuk diketahui sebagai pemetaan para pelaku dalam persoalan ini. 


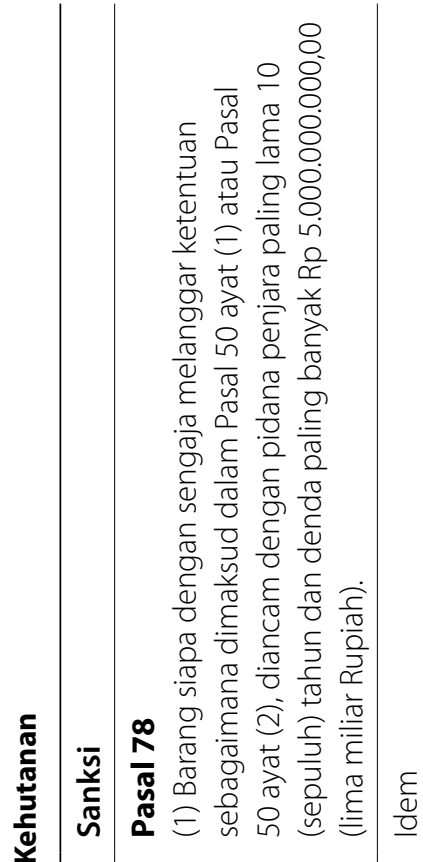

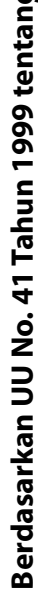

ล

$\frac{1}{10}$
$\frac{5}{8}$
$\dot{0}$

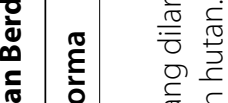

疍

苞

\section{它}

$\frac{\sqrt{0}}{\stackrel{0}{2}}$

중 당

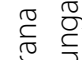

豞 亭

흔

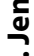

$\frac{\dot{m}}{\overline{0}}$ $\frac{0}{0}$

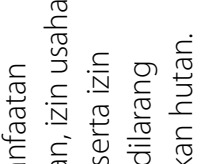

है Оु

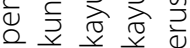

व

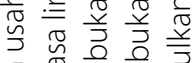

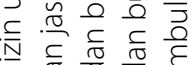

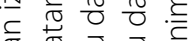

त

बे व

कृष्च है

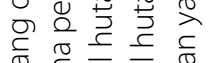

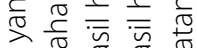

잉

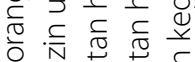

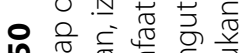

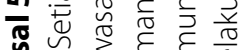

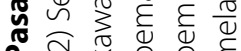

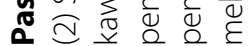

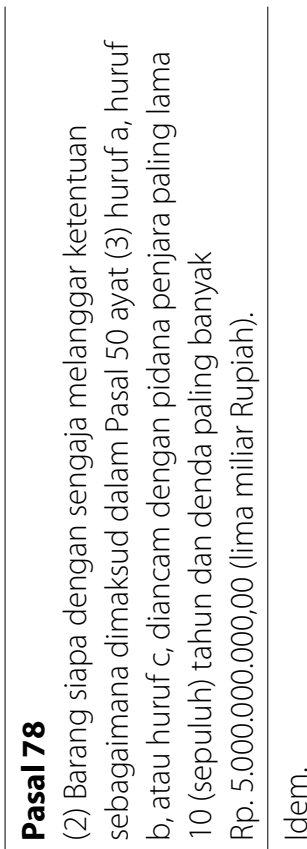

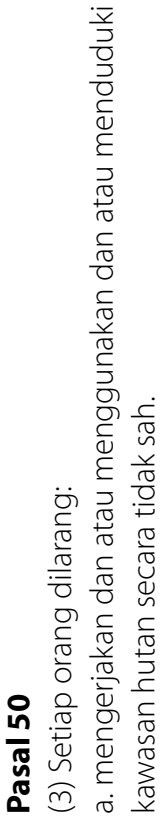

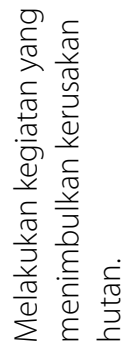

$\frac{\sqrt{5}}{\stackrel{5}{\frac{5}{5}}}$

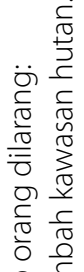

우 음 $\frac{0}{0}$

万ั

है

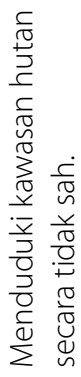

$\frac{\varepsilon}{\underline{\theta}}$

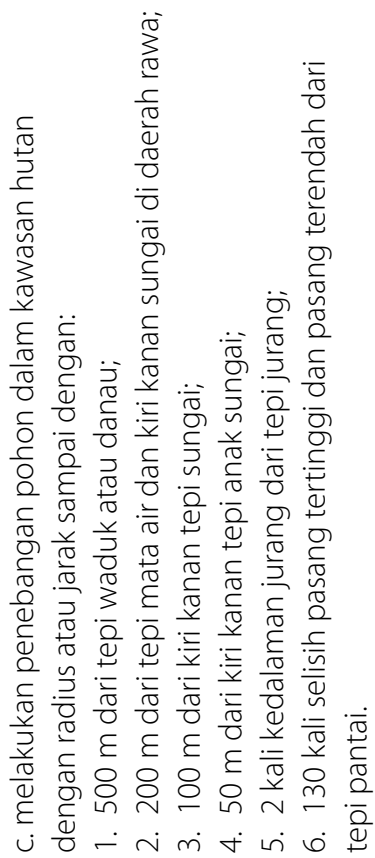

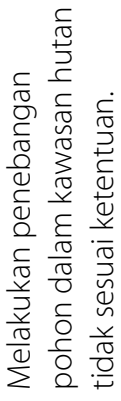




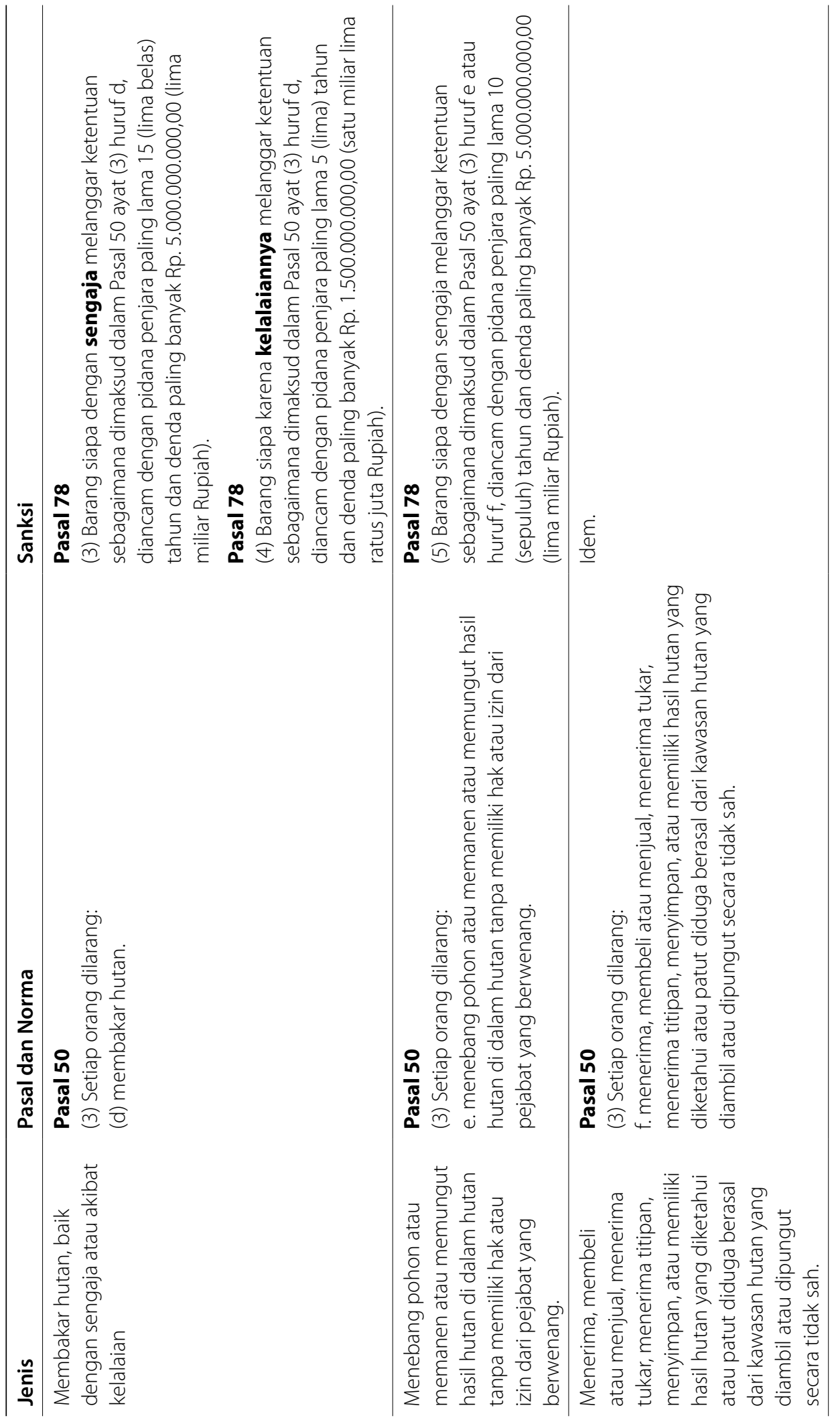




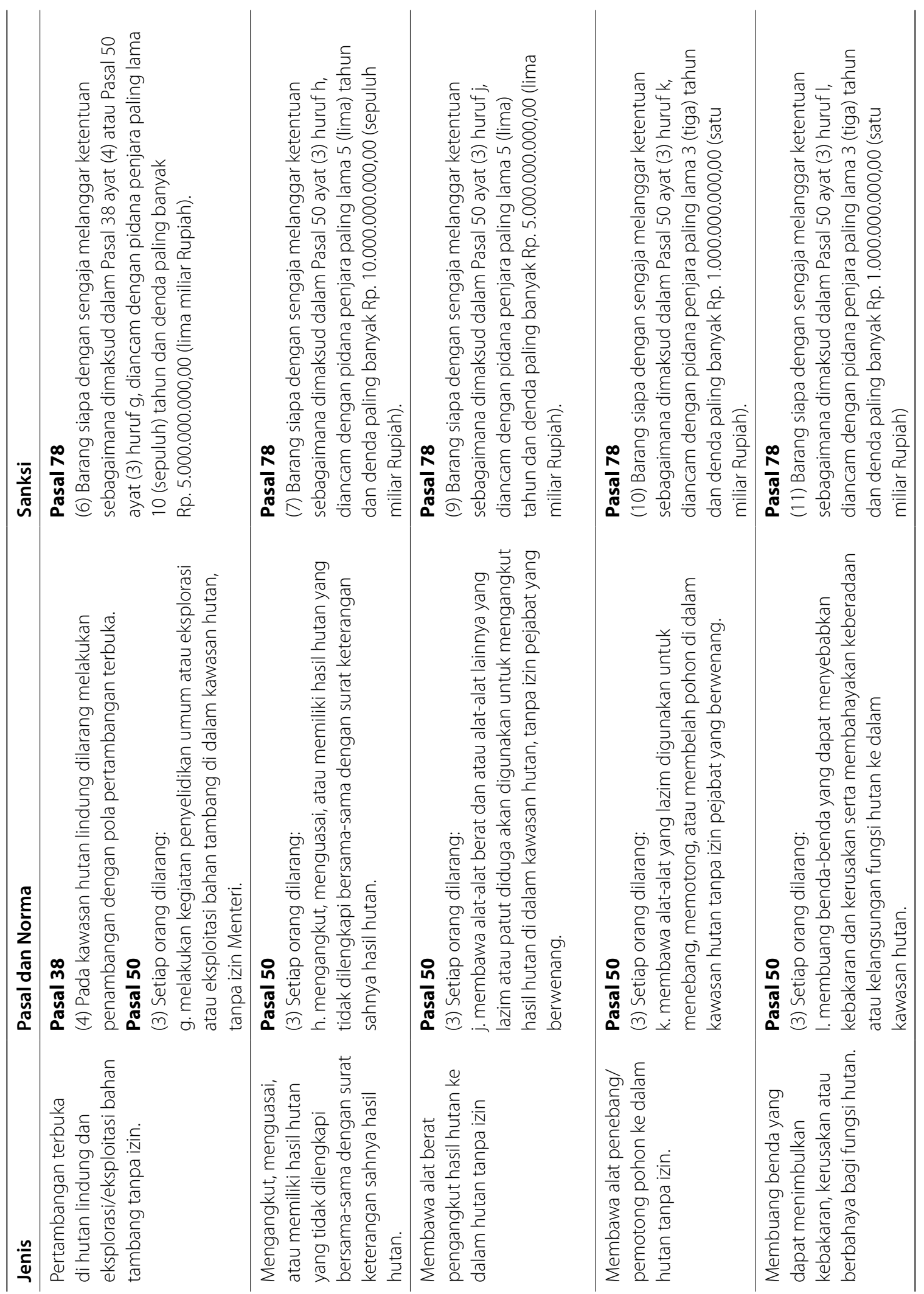




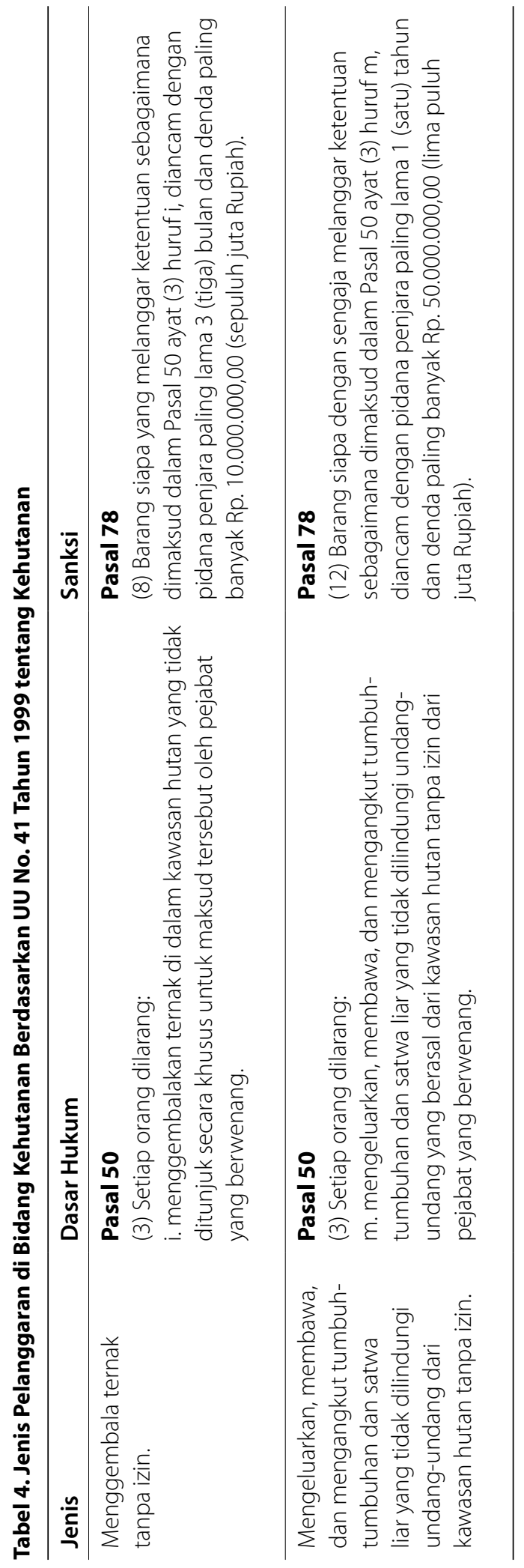


Dalam buku panduan ini pokok pembahasan hanya dibatasi pada kejahatan tindak pidana di bidang kehutanan seperti diklasifikasikan dalam Tabel 3. Berkaitan dengan kegiatan pembalakan, selain klasifikasi kejahatan yang didasarkan pada UU Kehutanan, kejahatan kehutanan dapat pula diklasifikasikan berdasarkan istilah yang banyak digunakan dalam isu lingkungan hidup, antara lain:

1. Pembalakan liar yaitu rangkaian kegiatan penebangan dan pengangkutan kayu ke tempat pengolahan hingga kegiatan ekspor kayu yang tidak mempunyai izin dari pihak yang berwenang sehingga tidak sah atau bertentangan dengan aturan hukum yang berlaku. Kegiatan ini dipandang sebagai perbuatan yang dapat merusak hutan (Suarga, 2005).

2. Pembalakan yang merusak (Destructive logging) yaitu penebangan hutan yang melanggar prinsip-prinsip kelestarian yang dilakukan oleh perusahaan kehutanan yang memiliki izin resmi dari pemerintah. ${ }^{8}$

\subsection{Bagaimana Penanganan Kejahatan di Bidang Kehutanan?}

Ketentuan dalam UU Kehutanan juga mengatur mengenai alur penanganan atas suatu kejahatan bidang kehutanan oleh penegak hukum. Berdasarkan KUHAP, maka pihak yang dapat berperan sebagai penyidik dalam kejahatan kehutanan adalah Penyidik Polri, Polisi Hutan, dan PPNS Departemen Kehutanan yang saling bekerja sama di bawah koordinasi penyidik Polri.

Selanjutnya, hasil penyidikan akan dilimpahkan kepada Kejaksaan Negeri untuk dapat dilakukan penuntutan oleh Jaksa Penuntut Umum (JPU) ke Pengadilan Negeri. Kemudian hakim yang memeriksa perkara yang diajukan akan memutus dengan pertimbangan-pertimbangan berdasarkan UU Kehutanan (lihat Gambar 1).

Umumnya penanganan tindak pidana di bidang kehutanan hanya diproses berdasarkan ketentuan dalam UU Kehutanan. Karena itu subyek kejahatan di bidang kehutanan, hanyalah perorangan sebagai pelaku perbuatan dan/ atau pengurus suatu badan hukum atau badan usaha yang terkait dengan kejahatan di bidang kehutanan. ${ }^{9}$ Sementara itu, ada pihak-pihak lain dalam mata rantai kejahatan ini yang tidak dapat dipidana apabila penegak hukum hanya mendasarkan pada UU Kehutanan. Pihak-pihak lain yang dimaksud antara lain adalah (1) pejabat pemerintah yang berwenang untuk mengeluarkan perizinan dan (2) pengusaha/pemilik modal yang secara tidak langsung terkait dengan badan usaha/badan hukum yang melanggar ketentuan bidang kehutanan.

Selain UU Kehutanan, seharusnya, undang-undang lainnya dapat juga digunakan untuk menjerat berbagai pihak yang terlibat melakukan tindak pidana di sektor

8 Sebagaimana diatur pada pasal 50 ayat (2) UU No. 41 Tahun 1999 tentang Kehutanan.

9 Berdasarkan Pasal 78 ayat (14) UU Kehutanan, apabila perbuatan kejahatan di atas dilakukan oleh dan atau atas nama badan hukum atau badan usaha, maka tuntutan dan sanksi pidananya dijatuhkan terhadap pengurusnya, baik sendiri-sendiri maupun bersama-sama, dengan tambahan $1 / 3$ (sepertiga) dari pidana yang dijatuhkan. 


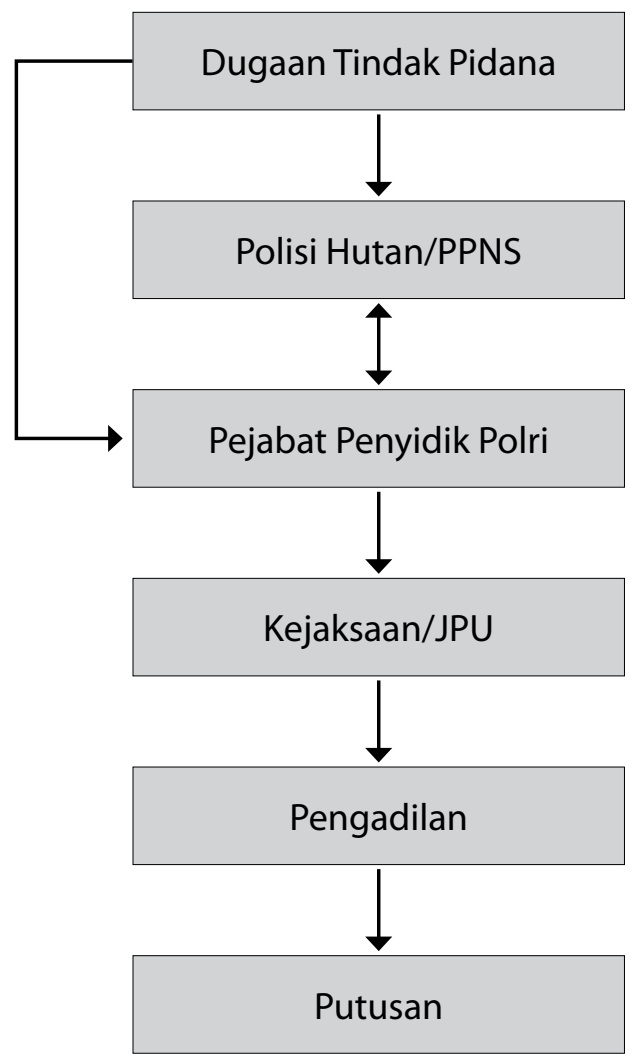

Gambar 1. Alur Penanganan Kejahatan di Bidang Kehutanan Berdasarkan UU No. 41 Tahun 1999

Sumber : Yuliastuti (2006)

kehutanan. Misalnya, UU Pemberantasan Tindak Pidana Korupsi dapat digunakan untuk menangani pejabat yang terlibat dalam mengeluarkan surat/ijin/dokumen tertentu untuk membantu pihak lainnya melakukan pembalakan liar. Demikian juga UU Pencegahan dan Pemberantasan Tindak Pidana Pencucian Uang (TPPU) dapat digunakan untuk menjerat para pelaku kejahatan kehutanan yang mengaburkan asal-usul hasil kejahatan tersebut agar mereka bisa menikmatinya.

Selanjutnya, barang bukti dalam kejahatan di bidang kehutanan yang didapat oleh penyidik di lapangan, seperti semua hasil hutan dari hasil kejahatan dan alat-alat (termasuk alat angkutnya) yang digunakan untuk melakukan kejahatan, akan dirampas untuk negara. Apabila dilihat sebagai suatu mata rantai, maka harta pelaku kejahatan yang patut diduga didapatkan dari hasil kejahatannya di bidang kehutanan juga perlu dipertanyakan. Hal ini dilakukan mengingat kerugian yang timbul akibat perbuatannya tersebut tidak hanya ditanggung oleh publik, namun juga merusak keseimbangan lingkungan hidup. 
Dalam hal sanksi yang diberikan kepada pelaku kejahatan di bidang kehutanan terdapat sanksi pidana dan administratif, serta keharusan untuk membayar ganti rugi sesuai dengan tingkat kerusakan atau akibat yang ditimbulkan kepada negara, seperti biaya rehabilitasi, pemulihan kondisi hutan, atau tindakan lain yang diperlukan. Oleh karena itu, untuk memberi efek jera kepada pelaku dalam mata rantai kejahatan di bidang kehutanan, dan melihat luasnya dampak kejahatan lingkungan yang harus ditanggung oleh publik, maka penegak hukum juga perlu mendasarkan penanganan suatu perbuatan kejahatan di bidang kehutanan pada ketentuan peraturan perundang-undangan selain UU Kehutanan.

Penelusuran terhadap peraturan perundang-undangan yang berlaku saat ini menunjukkan adanya beberapa undang-undang yang bisa diterapkan untuk penanganan kejahatan kehutanan, yaitu:

a. UU No. 20 Tahun 2001 tentang Perubahan atas UU No. 31 Tahun 1999 tentang Pemberantasan Tindak Pidana Korupsi;

b. UU No. 8 Tahun 2010 tentang Pencegahan dan Pemberantasan Tindak Pidana Pencucian Uang;

c. UU No. 32 Tahun 2009 tentang Perlindungan dan Pengelolaan Lingkungan Hidup; dan

d. UU No. 17 Tahun 2006 tentang Kepabeanan.

Selain itu, saat ini juga sedang dibahas RUU tentang Pencegahan dan Pemberantasan Pembalakan Liar dan RUU tentang Intelijen Negara ${ }^{10}$, yang intinya terkait dengan kejahatan kehutanan. Untuk itu perlu dilakukan penyesuaian antara penanganan kejahatan kehutanan dalam buku panduan ini dengan RUU tersebut.

Dalam panduan ini hanya akan dibahas mengenai penanganan kejahatan di bidang kehutanan melalui penerapan tindak pidana korupsi dan tindak pidana pencucian uang. Penerapan kedua produk hukum ini memberikan kekuatan kepada Kejaksaan melalui Surat Edaran Jaksa Agung tentang penerapan tindak pidana korupsi bagi kejahatan kehutanan dan Surat Edaran Jaksa Agung Muda Pidana Umum (Jampidum) No. B-689/E/EJP/12/2004 tentang penggunaan dakwaan kumulatif dalam perkara yang memiliki predicate crime dan tindak pidana pencucian uang sekaligus.

Meskipun sudah banyak upaya yang dilakukan untuk menanggulangi kejahatan di bidang kehutanan, masih banyak kelemahan yang ditemukan dan perlu perbaikan di masa mendatang. Kelemahan ini antara lain:

a. pelaku yang dipidana hanya yang tertangkap tangan;

b. pelaku banyak yang bebas atau mendapat hukuman ringan. Studi yang dilakukan oleh ICW menunjukkan bahwa pada putusan-putusan hakim dalam kasus-kasus kehutanan dari tahun 2005 hingga 2008, dari 205 kasus yang terpantau, sekitar 137 orang atau kurang lebih 66,83 \% diantaranya divonis bebas (ICW 2008). Selain itu, sebuah penelitian lain juga menemukan fakta yang sama, dimana pelaku

10 Dalam RUU Intelijen Negara, informasi/hasil kerja intelijen dimungkinkan untuk dijadikan alat bukti/bahan awal untuk memulai penyelidikan dan penyidikan. 
kejahatan kehutanan rata-rata dihukum pidana penjara mulai 1 hingga 8 bulan dan dengan denda berkisar Rp. 2.000.000 hingga Rp. 7.000.000.

c. putusan pengadilan tidak memenuhi rasa keadilan masyarakat. Dengan ringannya hukuman yang diberikan terhadap pelaku kejahatan kehutanan yang mengakibatkan kerugian negara dalam jumlah besar, maka bisa dikatakan bahwa putusan pengadilan belum bisa memenuhi rasa keadilan masyarakat;

d. rendahnya penggantian kerugian negara akibat upaya penyitaan hasil kejahatan yang belum maksimal. Selain itu, UUKehutanan sendiri hanya mematok angka Rp. 10 milyar sebagai denda maksimum bagi pelaku kejahatan kehutanan. Jumlah ini umumnya lebih kecil dari jumlah kerugian negara yang ditimbulkan oleh kejahatan kehutanan itu sendiri;

e. pejabat yang terlibat dan pihak-pihak yang menyuap pejabat, serta pencucian uang hasil kejahatan kehutanan tidak tersentuh. Hal ini terjadi karena Undang-undang Kehutanan tidak mengatur secara khusus tindak pidana korupsi dan tindak pidana pencucian uang yang terjadi di sektor kehutanan. Aturan mengenai tindak pidana korupsi tersebut diatur dalam undang-undang yang lain.

Karena kelemahan-kelemahan tersebut, maka kejahatan di bidang kehutanan seharusnya tidak hanya diatasi dengan menggunakan kerangka hukum UU Kehutanan saja, tetapi juga menggunakan UU Pemberantasan Korupsi dan UU Pencegahan dan Pemberantasan Pencucian Uang. Untuk menerapkannya tentu saja akan bergantung pada peranan pihak-pihak yang terlibat dan perbuatan yang dilakukannya. Diskusi mengenai bagaimana menerapkan kedua undang-undang tersebut akan dilakukan lebih lanjut dalam Bab 4 dan Bab 5. 



\section{Pendekatan ILEA dalam Penanganan Kejahatan di Bidang Kehutanan}

Untuk mengatasi berbagai kelemahan dalam penanganan kasus-kasus kejahatan di bidang kehutanan diperlukan pendekatan baru yang terpadu. Sejak tahun 2002, CIFOR telah mendorong penggunaan instrument hukum lain yaitu undang-undang anti pencucian uang untuk menjerat pelaku kejahatan kehutanan. Di tahun 2007, studi tersebut dikembangkan dengan yang mendorong penggunaan instrument anti korupsi dan anti pencucian uang melalui studi penegakan hukum terpadu. Pendekatan penegakan hukum ini disebut Integrated Law Enforcement Approach (ILEA) atau Pendekatan Penegakan Hukum Terpadu. Pendekatan ini tidak dapat dilakukan dengan baik tanpa adanya perangkat dan komponen yang relevan. Perangkat merupakan sarana atau alat yang diperlukan untuk dapat melaksanakan pendekatan penegakan hukum yang terpadu, sementara komponen merujuk pada lembaga-lembaga yang berperan dalam melaksanakan pendekatan ILEA ini.

Bagian ini menguraikan landasan konseptual Model ILEA yang digunakan untuk menanggulangi kejahatan pembalakan liar dan kejahatan lain yang terkait dengannya. Pendekatan ini berbeda dengan pendekatan yang umum digunakan, yaitu hanya membidik pelaku pembalakan liar dengan menggunakan kerangka hukum dan lembaga terkait dengan bidang kehutanan. Pendekatan ini mencakup berbagai perangkat dan lembaga yang lebih luas dan hasilnya diharapkan lebih optimal dalam melindungi hutan dan sektor kehutanan Indonesia.

\subsection{Perangkat ILEA}

\section{a. Pengembalian Aset (Stolen Asset Recovery Initiative - StAR Initiative)}

Dalam urusan korupsi, mekanisme pengembalian aset dipandang penting karena semakin banyak negara melakukan usaha pengembalian aset hasil korupsi pejabat tingginya di luar negeri yang dimulai pada tahun 1980-an. Proses pengembalian aset ternyata tidak mudah, karena bentuknya sering sudah berubah dan sengaja disembunyikan di dalam sistem dan infrastruktur keuangan yang mapan di negaranegara maju. Usaha ini membuktikan anggapan yang selama ini disangkal mengenai keterlibatan lembaga keuangan dan para pelaku mediasi (seperti oknum pengacara, akuntan, agen real estate, dll.) dari negara-negara maju dalam memfasilitasi masuknya dan penyembunyian aset-aset kotor dari para koruptor di negara-negara berkembang.

Pengembalian aset ini meliputi proses peradilan pidana maupun perdata untuk mencari, membekukan, dan mengembalikan dana yang didapatkan dari kegiatan yang dipandang 
sebagai perbuatan yang melanggar hukum ke negara yang meminta (berhak atas aset yang bersangkutan). Proses ini membutuhkan kerja sama yang baik antarnegara. Selain proses pengembalian, penggunaan aset yang telah dikembalikan itu harus tetap diawasi agar benar-benar digunakan untuk peningkatan kesejahteraan rakyat di negara berkembang.

\section{b. Prinsip mengenal Pengguna Jasa (Know Your Customer Principles)}

Prinsip Mengenal Pengguna Jasa harus diterapkan oleh setiap penyedia jasa agar pencegahan dan pemberantasan tindak pidana pencucian uang dapat berjalan efektif. Prinsip ini menjadi kewajiban penyedia jasa maupun pengguna jasa sebagaimana dimaksud dalam Bab IV, Bagian Kedua Tentang Penerapan Prinsip Mengenali Pengguna Jasa UU No. 8 Tahun 2010 tentang Pencegahan dan Pemberantasan Tindak Pidana Pencucian Uang TPPU. Berdasarkan PBI No. 3/23/PBI/2001 dan PBI No. 5/21/ PBI/2003 Prinsip Mengenal Nasabah (PMN) yang diterapkan oleh bank adalah untuk:

1. Mengetahui identitas nasabah (termasuk profil nasabah);

2. Memantau kegiatan transaksi nasabah; dan

3. Melaporkan transaksi keuangan yang mencurigakan kepada Pusat Pelaporan dan Analisis Transaksi keuangan (PPATK)

Prinsip Mengenal Nasabah tersebut telah diperbarui dengan PBI No. 11/28/PBI/2009 tentang penerapan program antipencucian uang dan pencegahan pendanaan terorisme bagi bank umum dan disempurnakan dengan Surat Edaran No. 11/31/2009 mengenai Pedoman Standar Penerapan Program Antipencucian Uang dan Pencegahan Pendanaan Terorisme bagi Bank Umum. ${ }^{11}$

Tingginya angka kejahatan di bidang kehutanan, terutama pembalakan liar, menyebabkan usaha di bidang kehutanan masuk ke dalam daftar usaha berisiko tinggi sehingga nasabah yang melakukan usaha di bidang kehutanan dan perkayuan juga masuk dalam daftar nasabah berisiko tinggi. Karena itu, melalui PMN ini bank diwajibkan untuk mengetahui profil dan memantau transaksi nasabah jika uang yang diperoleh tersebut dikhawatirkan berasal dari kegiatan ilegal (Setiono dan Yunus 2005). Dengan dukungan sistem informasi maka pihak perbankan dapat mengidentifikasi, menganalisis, memantau dan menyediakan laporan secara efektif mengenai karakteristik transaksi yang dilakukan oleh nasabah bank sehingga ketika terjadi transaksi yang mencurigakan atau tidak wajar maka pihak bank wajib segera melaporkan kepada PPATK.

\section{c. Tokoh yang Secara Politis Dipercaya Publik (Politically Exposed Persons)}

Politically Exposed Persons [PEPs] merupakan istilah baru dalam pengawasan konsumen lembaga keuangan dalam rangka pencegahan kejahatan keuangan, terutama pencucian uang. Munculnya PEPs didorong oleh kebutuhan untuk mengawasi secara lebih detil daftar calon konsumen yang berisiko besar bagi reputasi lembaga keuangan. Sampai saat ini konsep ini masih dalam tahap pengembangan mekanismenya. Politically

11 Sehubungan dengan diterbitkannya Undang-Undang yang mengatur mengenai Tindak Pidana Pencucian Uang (UU No. 8 Tahun 2010), hingga saat pedoman ini dituliskan, belum ada perubahan terhadap aturan perbankan yang mengatur mengenai Prinsip Mengenal Nasabah. 
Exposed Persons umumnya dikonotasikan sebagai orang-orang yang memiliki kekuasaan dalam pemerintahan, umumnya orang-orang yang memiliki jabatan tinggi dan sangat dikenal oleh publik. Pusat Pelaporan dan Analisis Transaksi Keuangan (PPATK) dalam pedomannya mendefinisikan PEPs sebagai:

...individu yang merupakan atau dipercayakan dengan fungsi-fungsi yang dikenal umum di suatu negara asing, misalnya kepala negara atau kepala pemerintahan, politisi senior, pejabat pemerintahan senior, petugas pengadilan atau militer, eksekutif senior BUMN, partisan, partai politik besar. Hubungan usaha dengan anggota keluarga atau sejawat terdekat PEP melibatkan risiko reputasi nama baik yang sama dengan dirinya sendiri. Definisi ini tidak termasuk ranking menengah atau individu yang lebih yunior dalam kategori sebelumnya. Hal ini berlaku bagi Warga Negara Indonesia maupun Warga Negara asing (PPATK 2008).

Mekanisme PEPs ini, sebagaimana disarankan oleh Financial Action Task Force (FATF), dilakukan dengan mewajibkan lembaga keuangan (ketika berhubungan dengan PEPs) untuk melakukan proses due diligence biasa, misalnya dalam bentuk PMN. Selain itu lembaga keuangan juga harus: (1) mempunyai suatu sistem manajemen risiko yang tepat untuk menentukan seseorang sebagai PEPs atau bukan; dan (2) mendapatkan persetujuan dari manajer senior sebelum hubungan bisnis dengan orang yang masuk dalam kategori PEPs dilakukan. PEPs ini masih beragam pelaksanaannya di lapangan. Beberapa negara bahkan memasukkan pejabat/politisi yunior dalam daftar PEPs.

\section{d. Bantuan Hukum Timbal Balik (Mutual Legal Assistance)}

Kejahatan pembalakan liar disinyalir merupakan kejahatan yang melintasi batas yurisdiksi negara. Kerja sama antara para penegak hukum lintas negara untuk mengejar pelaku dan mengembalikan aset yang disembunyikan merupakan suatu keharusan. Selain melalui saluran diplomatis, saat ini sudah dikenal pula mekanisme Bantuan Hukum Timbal Balik (Mutual Legal Assistance - MLA).

MLA merupakan mekanisme pemberian bantuan hukum berdasarkan hukum pidana yang dilakukan oleh satu otoritas (penegak hukum) dari satu negara ke penegak hukum di negara lain sebagai respon atas permintaan bantuan. Bantuan hukum ini antara lain dapat berbentuk pengejaran dan penangkapan pelaku, penyelidikan dan pemberian bukti kejahatan, pengembalian aset dan pelaku kejahatan, dan peningkatan kapasitas penegak hukum.

Berdasarkan UU No. 1 Tahun 2006 tentang Bantuan Timbal Balik dalam Masalah Pidana, khususnya Pasal 57, kerja sama MLA yang berlaku sekarang terdiri dari tiga bentuk. Pertama, berdasarkan perjanjian bilateral dua negara; kedua, berdasarkan perjanjian regional yang mengatur MLA; dan ketiga, berdasarkan perjanjian internasional. MLA ini baru berlaku setelah masing-masing negara meratifikasi perjanjian tersebut.

\section{e. Sistem Informasi Geografis (Geographic Information System)}

Geographic Information System (GIS) merupakan suatu sistem komputer yang mempunyai kemampuan pemasukan, pengambilan, analisis data dan tampilan data 
geografis yang sangat berguna bagi pengambilan keputusan (ESRI 1995). Manfaat utama GIS adalah kemampuannya menyajikan data spasial yang dilengkapi informasi geografis yang ditangkap dari peta atau data atribut suatu lokasi. GIS juga mampu menerima peta dari berbagai skala dan proyeksi dan mengubahnya ke dalam skala standar sehingga hasil yang diperoleh juga menjadi standar.

Aplikasi GIS sudah banyak digunakan untuk pengelolaan tata guna lahan di bidang pertanian, kehutanan dan pembangunan pemukiman penduduk serta fasilitasnya. Salah satu kegunaannya untuk bidang kehutanan adalah menghitung tingkat dan besaran serta lokasi terjadinya deforestasi. Dengan menggunakan GIS, analisis spasial dapat dilakukan dengan mudah dan cepat, demikian pula pemantauan terhadap perubahan tutupan hutan. Karena itu GIS juga menjadi alat kontrol yang efektif untuk mengukur sudah sejauh mana hutan dikelola dengan berkelanjutan oleh para pihak yang berkepentingan dengan hutan.

\section{f. Memperkirakan Kerugian Lingkungan dan Kerugian Negara}

Pendekatan ILEA dengan menggunakan UU Antikorupsi dan Antipencucian Uang terkait erat dengan besarnya kerugian negara yang disebabkan oleh praktik-praktik kejahatan kehutanan. Karena itu menghitung atau memperkirakan besarnya biaya kerusakan lingkungan dan jumlah kerugian negara akibat deforestasi dan pembalakan liar menjadi penting. Berdasarkan Wasis (2008) dalam Menteri Lingkungan Hidup (2006), memperkirakan biaya kerusakan lingkungan dapat dilakukan dengan menghitung biaya akibat kerusakan ekologis, kerugian ekonomi dan biaya yang harus dikeluarkan untuk pemulihan lingkungan.

Penghitungan kerusakan ekologis dilakukan secara tidak langsung berdasarkan kehancuran lingkungan akibat kerusakan hutan dan lahan. Kerugian ini dihitung melalui biaya pembuatan waduk atau dam, biaya pengaturan tata air, biaya pengendalian erosi dan limpasan, biaya pembentukan tanah, biaya pendaur ulang unsur hara, biaya pengurai limbah, biaya keanekaragaman hayati, biaya sumber daya genetis, serta biaya pelepasan karbon per hektar. Berdasarkan penjelasan Pasal 32 UU No. 31 tahun 1999 tentang Pemberantasan Tindak Pidana Korupsi (selanjutnya UU Pemberantasan Korupsi), besarnya kerugian negara didasarkan pada temuan lembaga berwenang (BPK/BPKP) atas hasil audit akuntan yang ditunjuk oleh penyidik (Wiyono 2006).

\subsection{Komponen ILEA}

\section{a. Lembaga-Lembaga Penegak Hukum}

Lembaga penegak hukum berperan sebagai pemimpin dalam upaya penegakan hukum memberantas pembalakan liar. Selain itu penegak hukum merupakan motor yang menggerakkan usaha memberantas pembalakan liar, karena fungsi dan kewenangannya. Lembaga penegak hukum berwenang untuk melakukan penyelidikan, penyidikan, penuntutan, pemeriksaan di pengadilan dan eksekusi terhadap putusan pengadilan dalam rangkaian upaya penegakan hukum terpadu. Lembaga ini mencakup PPNS Departemen kehutanan, Penyidik Polri, Penyidik Kejaksaan, Penyidik KPK, Penuntut 
Umum dan Hakim. Dalam hal pemberantasan korupsi, KPK misalnya, berwenang untuk menyelidiki keberadaan aset yang dimiliki oleh tersangka. Aset ini kemudian bisa dirampas apabila tersangka terbukti bersalah di pengadilan.

\section{b. Pusat Pelaporan dan Analisis Transaksi Keuangan}

PPATK merupakan komponen yang khas dan penting dalam pendekatan ILEA.

Sebagai intelijen keuangan, PPATK berperan sebagai pengolah data transaksi keuangan yang mencurigakan yang disediakan oleh penyedia jasa keuangan. Selain itu, PPATK berperan sebagai penyedia informasi analisis transaksi keuangan yang mencurigakan. Kalau fokus pendekatan penegakan hukum terhadap pembalakan liar selama ini hanya pada pencurian kayu, pendekatan ILEA menyelidiki arus uang yang diduga berasal dari kegiatan pembalakan liar. Karena itu, komponen intelijen keuangan berperan penting.

Hasil analisis PPATK terhadap transaksi keuangan yang mencurigakan bisa digunakan sebagai dasar bagi penegak hukum untuk menyelidiki pihak-pihak yang terlibat atau yang menerima dan memberikan uang dalam kejahatan pembalakan liar. Analisis inilah yang kemudian menjadi informasi awal dan dapat dikembangkan oleh penegak hukum untuk mengidentifikasi aliran uang dari kejahatan di sektor kehutanan dan pihak-pihak yang terlibat dalam kejahatan tersebut.

\section{c. Sektor-Sektor yang Terkait dengan Kehutanan}

Sektor kehutanan berperan sebagai penyedia informasi bagi penegak hukum dalam menyukseskan penegakan hukum terhadap pembalakan liar. Dalam hal ini Departemen Kehutanan berfungsi sebagai lembaga negara yang mengelola hutan dan sumber daya yang terkandung di dalamnya. Komponen ini mencakup Departemen Kehutanan, termasuk lembaga kehutanan lainnya yang terdapat di daerah, pelaku bisnis kehutanan, dan profesional di bidang kehutanan (termasuk pengacara bagi bisnis kehutanan).

Fungsi khusus Departemen Kehutanan dalam pendekatan ILEA adalah sebagai penyedia informasi yang berkaitan dengan peta kepemilikan hak pengusahaan hutan, luas hutan Indonesia, rancangan tata ruang dan wilayah, rencana kerja pemilik HPH (misalnya, rancangan kerja tahunan, rancangan kerja lima tahun), dan informasi lainnya yang terkait dengan tata kelola kehutanan.

\section{d. Lembaga Audit}

Lembaga ini berperan sebagai penyedia informasi bagi penegak hukum dalam menentukan indikasi adanya korupsi dalam pengelolaan hutan dan informasi besaran kerugian negara akibat kejahatan ini. Komponen ini terdiri dari Badan Pemeriksa Keuangan, Badan Pemeriksaan Keuangan dan Pembangunan, Irjen Departemen Kehutanan, dan Akuntan yang ditunjuk.

\section{e. Lembaga-Lembaga Keuangan dan Penyedia Jasa Lainnya}

Lembaga keuangan berperan sebagai penyedia informasi yang spesifik mengenai transaksi keuangan yang mencurigakan yang dilakukan oleh penyedia jasa keuangan dan penyedia barang dan/atau jasa lainnya. Komponen dari penyedia jasa keuangan 
mencakup adalah Bank Indonesia, bank umum, perusahaan pembiayaan, perusahaan asuransi dan perusahaan pialang asuransi, dana pensiun lembaga keuangan, perusahaan efek, manajer investasi; custodian, wali amanat, perposan sebagai penyedia jasa giro, pedagang valuta asing; penyelenggara alat pembayaran menggunakan kartu, penyelenggara e-money dan/atau e-wallet, koperasi yang melakukan kegiatan simpan pinjam, pegadaian, perusahaan yang bergerak di bidang perdagangan berjangka komoditas; atau penyelenggara kegiatan usaha pengiriman uang. Adapun komponen dari penyedia barang dan/atau jasa lainnya mencakup perusahaan properti/agen property, pedagang kendaraan bermotor, pedagang permata dan perhiasan/logam Mulia, pedagang barang seni dan antik; atau balai lelang.

Lembaga-lembaga ini dapat memberikan keterangan lain mengenai harta kekayaan setiap orang yang telah dilaporkan oleh PPATK, tersangka, atau terdakwa. Jika diminta oleh penegak hukum, lembaga keuangan dapat memblokir harta yang diduga merupakan hasil kejahatan kehutanan atau korupsi, sebagaimana diatur dalam Pasal 71 UU No. 8 Tahun 2010 tentang Pencegahan dan Pemberantasan Tindak Pidana Pencucian Uang TPPU.

Dalam kaitannya dengan Prinsip Mengenal Nasabah (PMN) dan Equator Principle ${ }^{12}$, penyedia jasa keuangan juga berfungsi sebagai pencatat dan pengawas nasabah yang termasuk dalam PEPs maupun menjalankan bisnis di bidang-bidang yang berisiko tinggi. Karena fungsi khususnya ini, penyedia jasa keuangan berperan penting dan perlu dimasukkan dalam pendekatan penegakan hukum terpadu terhadap pembalakan liar atau kejahatan lainnya di bidang kehutanan.

\section{f. Masyarakat Madani}

Masyarakat madani dapat berperan sebagai penyedia informasi bagi usaha pemberantasan penebangan liar. Komponen ini mencakup berbagai lembaga swadaya masyarakat, organisasi kemasyarakatan, organisasi internasional, dan para donor. Lembaga-lembaga ini khususnya bergerak di bidang lingkungan dan kehutanan, dan banyak terlibat dalam advokasi kasus-kasus yang berkaitan dengan pembalakan liar. Masyarakat madani ini bahkan juga mampu menyediakan data informasi geografis yang sangat penting bagi pengusutan kasus-kasus pembalakan liar sehingga peranan mereka penting bagi pendekatan penegakan hukum terpadu.

\subsection{Langkah-Langkah Penanganan Pembalakan Liar dengan Konsep Pendekatan Penegakan Hukum Terpadu (ILEA)}

Tabel 5 menunjukkan langkah-langkah yang dapat dilakukan dalam menanggulangi pembalakan liar dengan menggunakan pendekatan ILEA, khususnya sebagai pedoman bagi aparat penegak hukum dengan memakai UU Pemberantasan Tindak Pidana Korupsi dan UU Pencegahan dan Pemberantasan Tindak Pidana Pencucian Uang.

12 Prinsip-prinsip Equator (EP) adalah seperangkat panduan yang sifatnya sukarela yang dikembangkan dan diadopsi oleh bank dan lembaga keuangan lainnya untuk mengidentifikasi dan mengelola isu-isu lingkungan dan sosial dalam pendanaan sebuah proyek. 


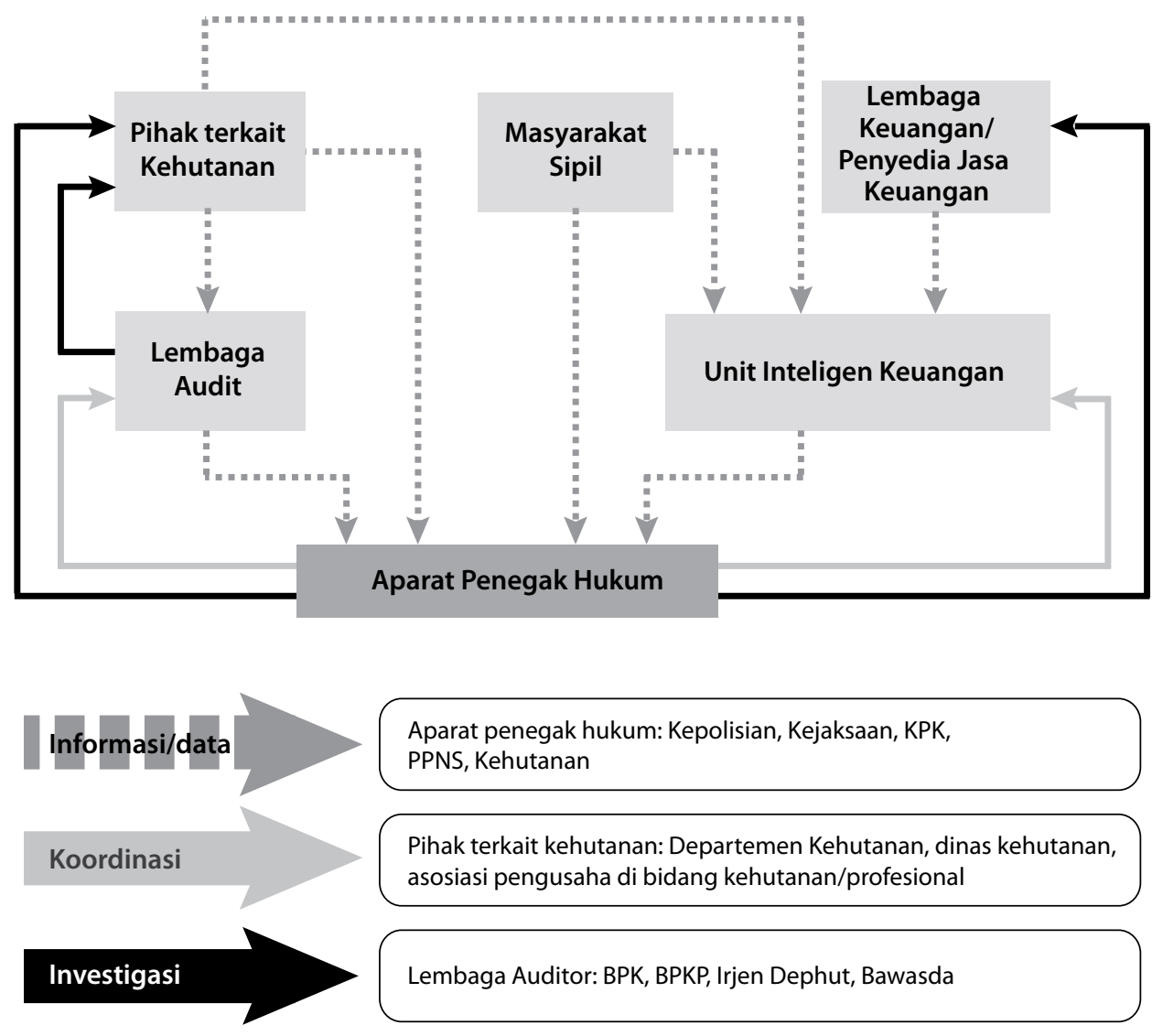

\section{Gambar 2. Model ILEA}

Uraian ringkas dalam Tabel 5 telah menjelaskan pendekatan yang ditawarkan dalam menanggulangi kejahatan di bidang kehutanan, dengan pendekatan yang lebih komprehensif. Dalam proses penanganan pembalakan liar, dasar hukum yang digunakan bukan hanya UU Kehutanan, tetapi juga UU Pemberantasan Tindak Pidana Korupsi dan UU Pencegahan dan Pemberantasan Tindak Pidana Pencucian Uang. Akan tetapi, selain penggunaan kedua perangkat hukum tersebut, pendekatan ini pun masih terbuka pada kemungkinan digunakannya perangkat hukum yang lain yang sesuai.

Bab 4 akan membahas aspek-aspek kejahatan korupsi dan kejahatan pencucian uang, khususnya mengenai unsur-unsur di dalam kedua bentuk kejahatan ini. Uraian tentang kedua bentuk kejahatan ini dikaitkan dengan pembalakan liar yang biasanya hanya menggunakan pendekatan dari UU Kehutanan saja. 


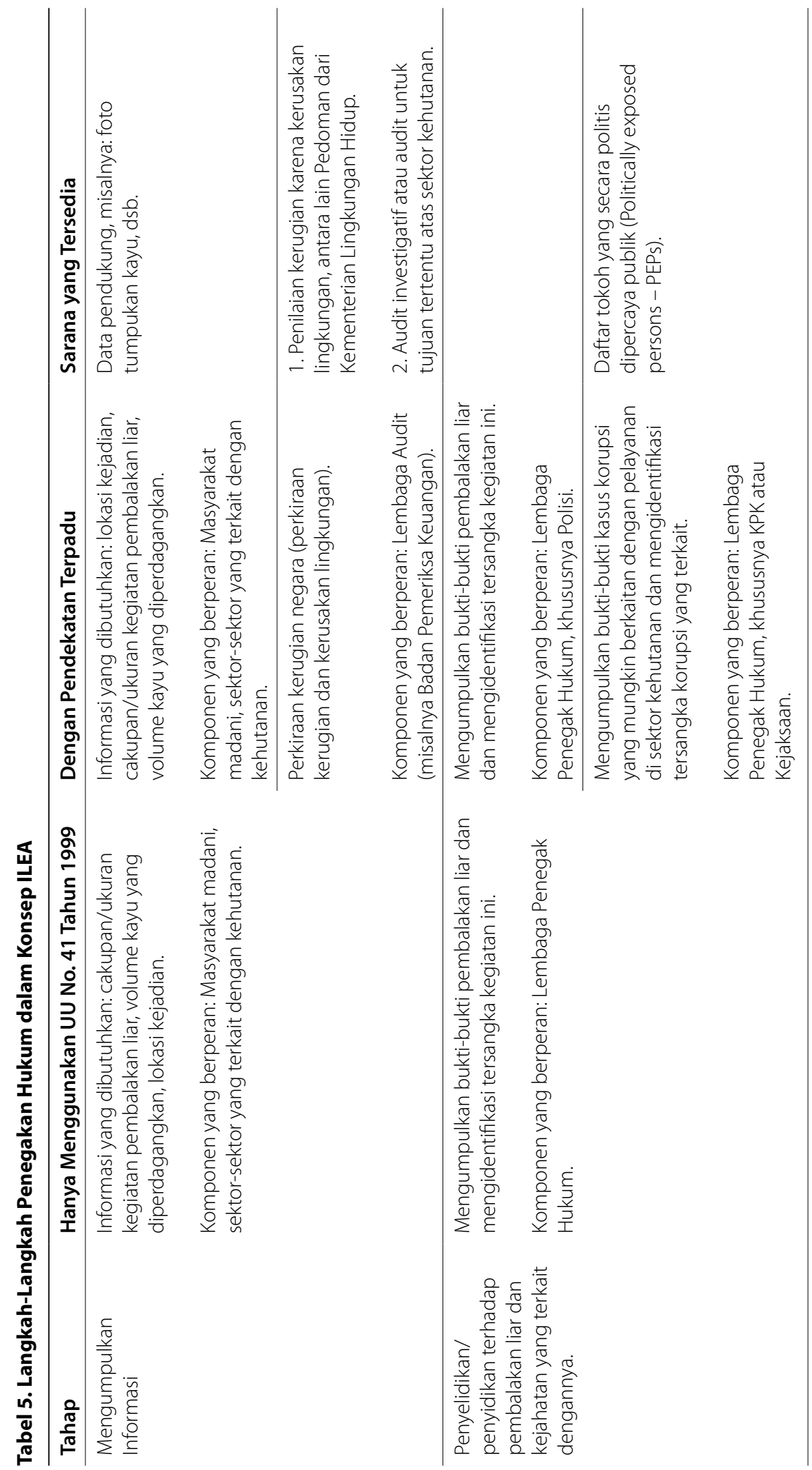




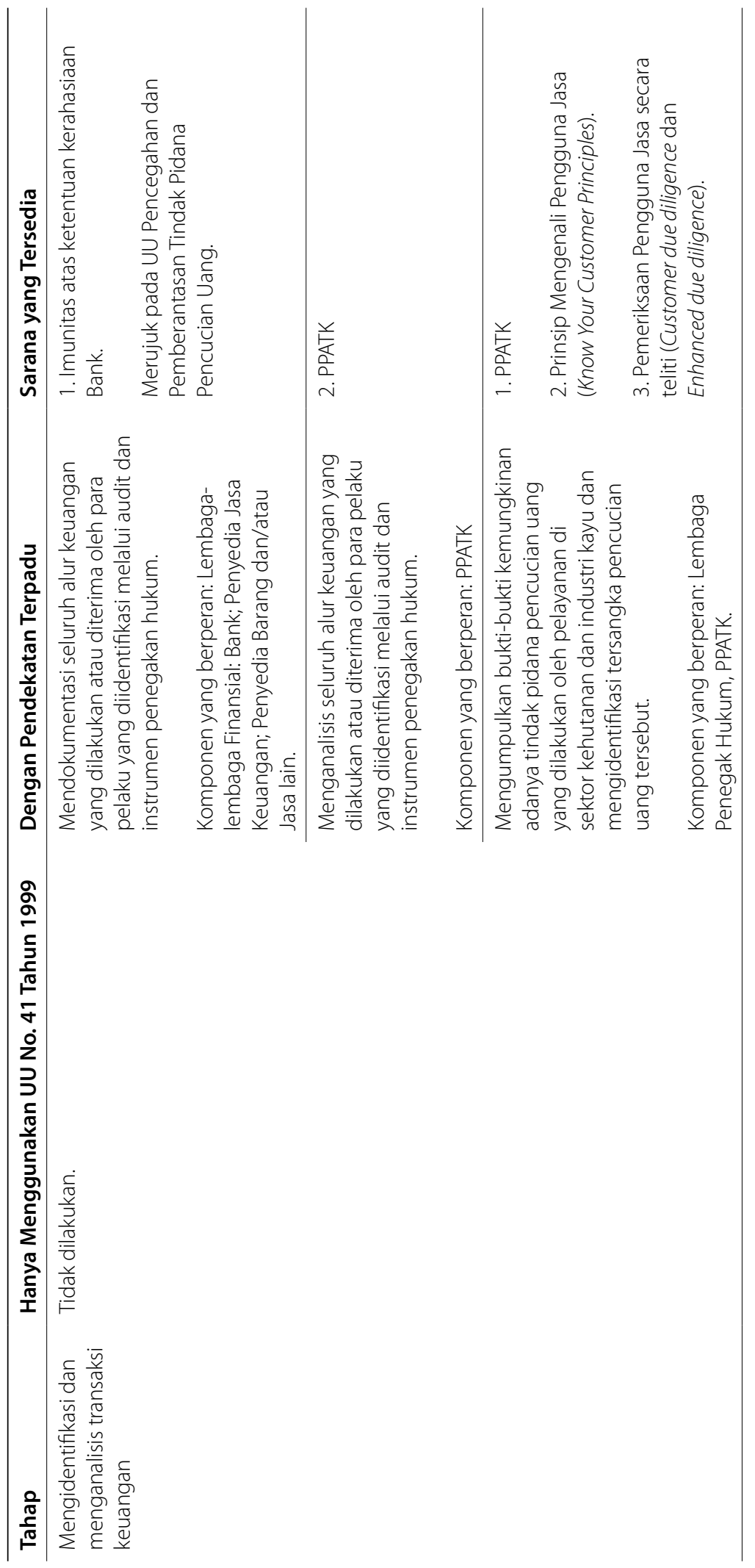




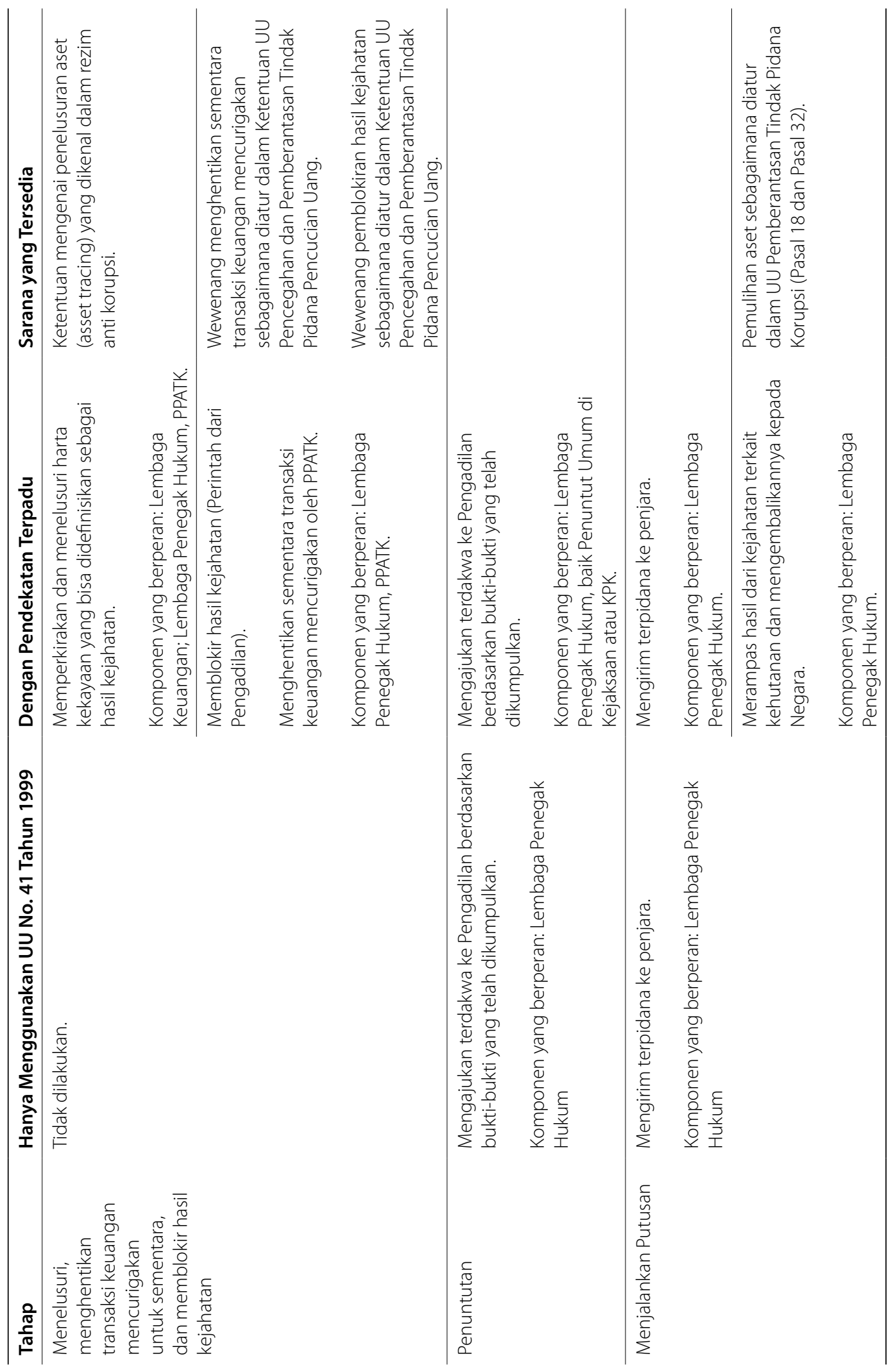




\section{4 \\ Tindak Pidana Korupsi dan Pencucian Uang serta Unsur-Unsurnya}

\subsection{Tindak Pidana Korupsi}

Menurut Transparency International, korupsi adalah 'penyalahgunaan kekuasaan publik untuk keuntungan pribadi'. ${ }^{13}$ Definisi ini juga dipakai oleh World Bank dalam mengartikan korupsi. ${ }^{14}$ Sementara dalam peraturan perundang-undangan korupsi yang ada di Indonesia definisi tindak pidana korupsi dijabarkan dalam tiga belas pasal dalam Undang-Undang Nomor 31 Tahun 1999 jo. Undang-Undang Nomor 20 Tahun 2001. Secara umum, definisi korupsi yang dimiliki Indonesia serupa dengan definisi yang digunakan oleh Transparency International dan World Bank, akan tetapi definisi korupsi yang dipakai di Indonesia juga memasukkan unsur timbulnya kerugian Negara. Unsur ini tidak dimiliki oleh definisi korupsi yang dimiliki oleh Transparency International ataupun World Bank.

Secara umum, beberapa faktor penyebab maraknya korupsi antara lain adalah penegakan hukum yang lemah (rendahnya probabilitas untuk tertangkap, dituntut dan dihukum serta keberadaan mafia hukum), administrasi birokrasi yang membuka peluang korupsi (perijinan, kewenangan yang luas, mata rantai birokrasi, dll.), gaji rendah, kesenjangan gaji, rendahnya etika dan moralitas.

Melalui UU No. 7 Tahun 2006 tentang Pengesahan Konvensi Perserikatan BangsaBangsa Antikorupsi 2003, Indonesia meratifikasi Konvensi PBB Antikorupsi Tahun 2003 (United Nations Convention Against Corruption - UNCAC 2003) dan menjadi Negara Peserta (state party) dari Konvensi tersebut. Prinsip-prinsip yang mendasari Konvensi ini adalah tanggung jawab pemerintah untuk mengembangkan kebijakankebijakan antikorupsi yang efektif, perlunya melibatkan masyarakat madani sebagai peserta dalam menerapkan kebijakan-kebijakan yang terkait, dan pentingnya kerja sama internasional bagi keefektifan langkah-langkah yang direkomendasikan oleh Konvensi ini.

Konvensi UNCAC meminta Negara pesertanya untuk menciptakan, atau mempertimbangkan untuk menciptakan, cara-cara penindakan berbagai bentuk

13 Transparency International mengartikan korupsi sebagai: "Corruption is operationally defined as the abuse of entrusted power for private gain”, sebagaimana dijabarkan di: http://www.transparency.org/ news_room/faq/corruption_faq [13 Februari 2011].

14 World Bank atau Bank Dunia menetapkan menggunakan kalimat: "The abuse of public office for private gain”, sebagai definisi korupsi mereka. Dapat dilihat di: http://www1.worldbank.org/ publicsector/anticorrupt/corruptn/cor02.htm, [13 Februari 2011]. 
korupsi. Namun kerangka hukum anti korupsi yang ada sekarang di Indonesia belum sepenuhnya mengadopsi bentuk-bentuk korupsi yang tercantum dalam UNCAC tersebut. Oleh karena itu, Pemerintah perlu segera membangun kerangka anti korupsi yang sesuai dengan UNCAC.

Bentuk korupsi yang harus dimasukkan antara lain adalah penyuapan kepada pejabat publik, penyuapan kepada pejabat publik asing, penyalahgunaan properti publik oleh pejabat publik, pemerkayaan diri secara tidak sah, penyuapan di sektor swasta, penggelapan properti di sektor swasta, pencucian hasil kejahatan, penyembunyian properti hasil kejahatan, dan menghalangi proses pengadilan.

Mengacu kepada berbagai bentuk korupsi di atas, upaya penegakan hukum atas korupsi di sektor kehutanan diharapkan akan lebih baik karena bentuk-bentuk korupsi tersebut relevan dengan praktek korupsi di sektor kehutanan yang selama ini terjadi di Indonesia. Selain itu, konvensi juga mengatur persoalan hukum acara yang lebih maju seperti pembatasan waktu untuk kejahatan korupsi (daluwarsa), ketentuan khusus soal yurisdiksi ekstrateritorial, penuntutan dan hukuman bagi mereka yang terlibat dalam kejahatan yang disebutkan dalam konvensi, langkah-langkah untuk membekukan, menyita dan memusnahkan hasil kejahatan, perlindungan bagi saksi-saksi, para informan, kaki tangan, dan adanya mekanisme untuk mengenyampingkan kebijakan mengenai Kerahasiaan Bank.

\subsubsection{Tipologi Korupsi di Sektor Kehutanan}

Paling sedikit terdapat tiga tipologi tindak pidana korupsi di dalam sektor kehutanan, khususnya yang terkait dengan: ${ }^{25}$ pemberian izin, pengawasan terhadap kegiatan usaha kehutanan, dan pengawasan terhadap usaha kehutanan berskala besar (Santoso 2009). Untuk korupsi yang terkait dengan pemberian izin, menurut penelitian Indonesian Corruption Watch, terdapat empat tipologi praktik korupsi (ICW 2004), seperti diuraikan berikut ini:

1. Korupsi Transaktif dilakukan oleh pejabat publik yang berwenang untuk menghindari 'kerugian' atau untuk mendapatkan 'keuntungan', misalnya untuk menghindari pajak atau kewajiban lainnya. Korupsi ini juga dilakukan untuk memudahkan praktik pembalakan liar dan penyelundupan kayu (berupa perlindungan dari penegak hukum atau perlindungan politik).

2. Korupsi Investif dilakukan untuk mendapatkan konsesi hutan, misalnya pejabat publik ingin mendapatkan izin konsesi ketika berperan sebagai pengambil keputusan atas alokasi konsesi hutan.

3. Korupsi Kekerabatan biasanya dilakukan melalui kemudahan hak pengelolaan sumber daya hutan kepada keluarga dan kerabat yang diberikan ketika pejabat tersebut sedang berkuasa.

4. Korupsi Defensif dilakukan untuk mencegah pihak tertentu memperoleh keuntungan atau memaksa pihak lain menanggung kerugian, misalnya dengan merekayasa persyaratan untuk menyisihkan pihak lain mengakses pemanfaatan hutan (ICW 2004). 
Tabel berikut adalah beberapa perkara tindak pidana korupsi yang terjadi di bidang kehutanan:

Tabel 6. Contoh Perkara Tindak Pidana Korupsi dalam Kejahatan di Bidang Kehutanan ${ }^{15}$

\begin{tabular}{lll}
\hline Kejahatan & Pasal & Kasus \\
\hline Bupati memberikan ljin HTI di & Pasal 3 UUPTPK & Bupati Pelalawan memberikan \\
hutan yang mempunyai potensi & (kerugian & ijin HTI untuk 15 perusahaan. \\
$\begin{array}{l}\text { pohon tinggi (melanggar } \\
\text { peraturan). }\end{array}$ & negara). & \\
\hline
\end{tabular}

Penebangan di luar RKT dan membayar DR PSDH lebih rendah dari kayu yang ditebang.
Pasal 2 UUPTPK AL menyuruh PT KNDI untuk (kerugian melakukan penebangan di luar negara).
RKT dan melakukan manipulasi pembayaran DR PSDH yang lebih rendah.

Seorang pejabat polisi menerima
uang Rp 1,065 miliar lebih dari
perusahaan kayu yang diduga
terlibat pembalakan liar, tetapi
melaporkan uang gratifikasi
tersebut ke KPK.

tersebut ke KPK.

Pasal 12 huruf
b UUPTPK
(gratifikasi).

$$
\text { (gratifikasi). }
$$

MR, seorang pejabat polisi menerima uang $\mathrm{Rp} 1,065$ miliar lebih dari PT Marindo Utama dan PT Sanjaya Makmur dengan alasan hutang piutang. Uang ini sebenarnya adalah uang suap supaya MR tidak melakukan penyelidikan terhadap kasus pembalakan liar yang dilakukan perusahaan kayu tersebut.

Menerima uang suap atas proses pengalihfungsian hutan lindung.
Pasal 12 huruf a UUPTPK (penyuapan).
ANN tertangkap tangan menerima uang suap dari Sekda Bintan, di Hotel Ritz Carlton pada 8 April 2008. ANN disinyalir menjadi penghubung antara Komisi IV DPR dengan Kabupaten Bintan dalam masalah pengalihfungsian hutan lindung menjadi kawasan Ibu Kota Kabupaten Bintan di Bintan Buyu, Kabupaten Bintan, Kepulauan Riau.

\subsubsection{Unsur-Unsur Tindak Pidana Korupsi yang Terkait dengan Kejahatan Kehutanan}

Penerapan atas bentuk-bentuk tindak pidana korupsi secara umum di atas dalam kejahatan kehutanan dapat diakomodasikan oleh pasal-pasal sebagaimana diuraikan di bawah ini. Untuk lebih memperjelas korelasi kejahatan kehutanan dengan tindak pidana korupsi, maka diterangkan pula setiap unsur pasalnya, sebagai berikut:

15 Diolah dari berbagai data kasus yang disajikan oleh Integrated Law Enforcement Approach Project (ILEAP) CIFOR. Data lebih lengkap dapat diakses di: http://www.cifor.cgiar.org/ilea/_ref/ home/index.htm. 


\section{a. Unsur-Unsur Tindak Pidana Korupsi dan Pengertiannya sesuai dengan Pasal 2 ayat (1) UU No. 20 Tahun 2001 jo UU No. 31 Tahun 1999}

Setiap orang yang melawan hukum dan memperkaya diri sendiri atau orang lain atau suatu korporasi yang dapat merugikan keuangan negara atau perekonomian negara

Setiap orang adalah orang perseorangan atau termasuk korporasi (berdasarkan Pasal 1 angka 3).

Melawan hukum berarti tanpa hak sendiri (zonder eigen recht) atau bertentangan dengan hak orang lain (tegen eens anders recht), atau tanpa alasan yang wajar, atau bertentangan dengan hukum positif. Sebelum adanya Putusan Mahkamah Konstitusi RI No. 003/PUU-IV/2006 tanggal 25 Juli 2006, melawan hukum mencakup perbuatan melawan hukum dalam arti formil maupun materil, yakni meskipun perbuatan tersebut tidak diatur dalam peraturan perundang-undangan, apabila dianggap tercela karena tidak sesuai dengan rasa keadilan atau norma-norma kehidupan sosial dalam masyarakat, maka dapat dipidana. Dalam ketentuan ini, kata 'dapat' sebelum frasa 'merugikan keuangan atau perekonomian negara' menunjukkan bahwa tindak pidana korupsi merupakan delik formil, yaitu adanya tindak pidana korupsi cukup dengan dipenuhinya unsur-unsur perbuatan yang sudah dirumuskan bukan dengan timbulnya akibat (berdasarkan penjelasan Pasal 2). Namun dengan adanya Putusan Mahkamah Konstitusi RI No. 003/PUU-IV/2006 tanggal 25 Juli 2006 yang menyatakan bahwa Penjelasan Pasal 2 ayat (1) telah bertentangan dengan UUD 1945 dan tidak mempunyai kekuatan hukum mengikat, maka penerapan melawan hukum dalam arti materil untuk tindak pidana korupsi sangat bergantung pada penilaian hakim. Dalam praktiknya, putusan Mahkamah Konstitusi tersebut tidak dipedomani secara mutlak oleh Mahkamah Agung berikut jajaran di bawahnya. Karena itu putusan Mahkamah Konstitusi tersebut tidak serta merta membatalkan pengertian melawan hukum dalam arti materil.

Memperkaya diri sendiri atau orang lain atau suatu korporasi adalah upaya untuk mengumpulkan kekayaan yang tidak setara dengan penghasilannya atau penambahan kekayaan dari sumber yang tidak sah (Sukardi 2009). Pengertian lain dari memperkaya adalah perbuatan yang dilakukan untuk menjadi lebih kaya, sedangkan berdasarkan putusan pengadilan negeri Tangerang tanggal 13 Mei 1992 No. 18/Pid/B-1992/PN/ TNG memperkaya adalah menjadikan orang yang belum kaya menjadi kaya atau yang sudah kaya bertambah kaya (Wiyono 2006).

Keuangan negara adalah kekayaan negara dalam bentuk apapun, yang dipisahkan atau tidak dipisahkan, termasuk bagian kekayaan negara dan hak/kewajibannya yang timbul karena berada dalam penguasaan, pengurusan dan pertanggungjawaban pejabat lembaga negara dan BUMN/BUMD, yayasan, badan hukum dan perusahaan yang menyertakan modal negara atau modal pihak ketiga berdasarkan perjanjian dengan negara.

Perekonomian negara adalah kehidupan perekonomian yang disusun sebagai usaha bersama berdasarkan asas kekeluargaan atau usaha masyarakat secara mandiri yang sesuai dengan kebijakan pemerintah yang bertujuan memberikan manfaat, kesejahteraan dan kemakmuran kepada rakyat (Sukardi 2009). 


\title{
b. Unsur-Unsur Tindak Pidana Korupsi dan Pengertiannya sesuai dengan Pasal 3 UU No. 20 Tahun 2001 jo UU No. 31 Tahun 1999
}

\begin{abstract}
Setiap orang yang dengan tujuan menguntungkan diri sendiri atau orang lain atau suatu korporasi menyalahgunakan kewenangan, kesempatan atau sarana yang ada padanya karena jabatan atau kedudukan yang dapat merugikan keuangan negara atau perekonomian negara.
\end{abstract}

Setiap orang adalah orang perseorangan atau termasuk korporasi (berdasarkan Pasal 1 angka 3).

\section{Dengan tujuan menguntungkan diri sendiri atau orang lain atau suatu korporasi} adalah upaya untuk mengumpulkan kekayaan yang tidak setara dengan penghasilannya atau penambahan kekayaan dari sumber yang tidak sah (Sukardi 2009). Pengertian lain dari 'menguntungkan' adalah dengan mendapatkan untung, yaitu pendapatan yang diperoleh lebih besar dari pengeluaran; di sini terlihat bahwa menguntungkan diri sendiri atau orang lain atau suatu korporasi merupakan tujuan dari pelaku tindak pidana korupsi (Wiyono 2006).

\section{Menyalahgunakan kewenangan, kesempatan atau sarana yang ada padanya} merujuk pada penjelasan Pasal 52 KUHP mengenai pegawai negeri yang melanggar kewajiban istimewa dalam jabatannya, atau memakai kekuasaan, atau sarana yang ada padanya yang diperoleh karena jabatan, atau menggunakan daya upaya atau alat yang diperoleh karena jabatan. Menurut Pasal 1 angka 2, pegawai negeri meliputi:

1. Pegawai negeri sebagaimana undang-undang tentang Kepegawaian;

2. Pegawai negeri sebagaimana dimaksud dalam Kitab Undang-undang Hukum Pidana;

3. Orang yang menerima gaji atau upah dari keuangan negara atau daerah;

4. Orang yang menerima gaji atau upah dari suatu korporasi yang menerima bantuan dari keuangan negara atau daerah; atau

5. Orang yang menerima gaji atau upah dari korporasi lain yang menggunakan modal atau fasilitas dari negara atau masyarakat.

Jabatan yang berkenaan dengan pegawai negeri dapat dilihat dalam penjelasan Pasal 17 ayat (1) UU No. 43 Tahun 1999 tentang Perubahan atas Undang-Undang No. 8 Tahun 1974 Tentang Pokok-Pokok Kepegawaian yang antara lain menyebutkan bahwa jabatan adalah kedudukan yang menunjukkan tugas, tanggung jawab, wewenang dan hak seorang PNS dalam organisasi negara. Pengertian lain dari kewenangan menurut Pasal 53 ayat (1) huruf b Undang-Undang No. 5 Tahun 1986 tentang Peradilan Tata Usaha Negara adalah serangkaian hak yang melekat pada jabatan atau kedudukan dari pelaku tindak pidana korupsi untuk mengambil tindakan yang diperlukan agar tugas pekerjaannya dapat dilaksanakan dengan baik. Sedangkan yang dimaksud kesempatan dalam pasal ini diperoleh sebagai akibat adanya kekosongan atau kelemahan dari ketentuan tentang tata kerja yang berkaitan dengan jabatan atau kedudukan sang pelaku tindak pidana korupsi. Selanjutnya yang dimaksud dengan sarana dalam pasal ini adalah cara kerja atau metode kerja yang berkaitan dengan jabatan atau kedudukan dari pelaku tindak pidana korupsi. Namun penerapan unsur menyalahgunakan sifatnya 
lebih luas, karena merupakan istilah umum dan tidak dirinci dalam penjelasan pasalnya (Sukardi 2009).

Jabatan atau kedudukan maksudnya menunjukkan bahwa pelaku adalah seorang pegawai negeri dengan jabatan tertentu. Dengan demikian perbuatan yang dilakukan oleh tersangka/terdakwa berhubungan dengan jabatan atau kedudukannya (Sukardi 2009).

Keuangan negara adalah kekayaan negara bisa dalam bentuk apapun, yang dipisahkan atau tidak dipisahkan, termasuk bagian kekayaan negara dan hak/kewajibannya yang timbul karena berada dalam penguasaan, pengurusan dan pertanggungjawaban pejabat lembaga negara dan BUMN/BUMD, yayasan, badan hukum dan perusahaan yang menyertakan modal negara atau modal pihak ketiga berdasarkan perjanjian dengan negara.

Perekonomian negara yaitu kehidupan perekonomian yang disusun sebagai usaha bersama berdasarkan asas kekeluargaan atau usaha masyarakat secara mandiri sesuai dengan kebijakan pemerintah dengan tujuan memberikan manfaat, kesejahteraan dan kemakmuran kepada rakyat (Sukardi 2009).

\section{c. Unsur-Unsur Tindak Pidana Korupsi dan Pengertiannya sesuai dengan Pasal 5 Ayat (1) a UU No. 20 Tahun 2001 jo UU No. 31 Tahun 1999}

Setiap orang adalah orang perseorangan atau termasuk korporasi (berdasarkan Pasal 1 angka 3).

Memberi atau menjanjikan sesuatu kepada pegawai negeri atau penyelenggara negara dengan maksud supaya pegawai negeri atau penyelenggara negara tersebut berbuat atau tidak berbuat sesuatu dalam jabatannya, yang bertentangan dengan kewajibannya.

Memberi atau menjanjikan sesuatu merujuk pada pengertian gratifikasi dalam penjelasan Pasal $12 \mathrm{~b}$ yaitu pemberian dalam arti luas, meliputi uang, barang, rabat (diskon), komisi, pinjaman tanpa bunga, tiket perjalanan, fasilitas penginapan, perjalanan wisata, pengobatan cuma-cuma, dan fasilitas lainnya. Gratifikasi ini diterima di dalam maupun di luar negeri dan dilakukan dengan menggunakan sarana elektronik atau tanpa sarana elektronik. Selanjutnya pengertian janji yaitu pemberian harapan untuk memberikan gratifikasi pada waktu tertentu dan dengan syarat tertentu (Sukardi 2009). Dalam putusan Mahkamah Agung RI No. $145 \mathrm{~K} / \mathrm{Kr} / 1955$, tanggal 22 Juni 1956 disebutkan bahwa pemberian itu tidak disyaratkan harus diterima, dan berdasarkan putusan Mahkamah Agung No. 39 K/Kr/1963, tanggal 3 Agustus 1963 disebutkan bahwa pemberian itu tidak perlu dilakukan pada waktu pegawai yang bersangkutan melaksanakan dinasnya, melainkan dapat juga diberikan di rumahnya.

Pegawai negeri atau penyelenggara negara maksudnya ialah:

a. pegawai negeri sebagaimana undang-undang tentang Kepegawaian; 
b. pegawai negeri sebagaimana dimaksud dalam Kitab Undang-undang Hukum Pidana;

c. orang yang menerima gaji atau upah dari keuangan negara atau daerah;

d. orang yang menerima gaji atau upah dari suatu korporasi yang menerima bantuan dari keuangan negara atau daerah; atau

e. orang yang menerima gaji atau upah dari korporasi lain yang mempergunakan modal atau fasilitas dari negara atau masyarakat.

Sedangkan yang dimaksud dengan penyelenggara negara dalam Pasal 2 UU No. 28 Tahun 1999 meliputi pejabat negara pada lembaga tertinggi negara, pejabat negara pada lembaga tinggi negara, menteri, gubernur, hakim, pejabat negara lain berdasarkan peraturan perundang-undangan, serta pejabat negara lain yang memiliki fungsi strategis.

Dengan maksud yaitu sesuatu perbuatan yang dilakukan oleh pelakunya harus diketahui, dikehendaki dan disadari akan akibatnya. Dalam hukum pidana dengan maksud bijkomend oogmerk atau maksud selanjutnya yang tidak perlu tercapai pada waktu pelaku tindak pidana selesai melakukan tindak pidana tersebut (Lamintang 1984). Hal ini sejalan dengan putusan Mahkamah Agung RI No. 39 K/Kr/1963, tanggal 3 Agustus 1963.

Berbuat atau tidak berbuat sesuatu dalam jabatannya maksudnya adalah supaya pegawai negeri atau penyelenggara negara tersebut berbuat atau tidak berbuat sesuatu dalam jabatannya karena pemberian atau janji untuk kepentingan si pemberi atau orang lain yang menjanjikan. Pemberian atau pemenuhan janji itu telah diselesaikan atau belum, dan perbuatan yang diinginkan oleh si pemberi belum dilaksanakan oleh pegawai negeri, namun sudah ketahuan atau tertangkap lebih dulu (Sukardi 2009).

Bertentangan dengan kewajibannya berarti perbuatan yang diinginkan atau tidak diinginkan oleh si pemberi itu bertentangan dengan kewajiban tugas jabatan pegawai negeri atau penyelenggara negara yang bersangkutan (Sukardi 2009).

\section{d. Unsur-Unsur Tindak Pidana Korupsi dan Pengertiannya sesuai dengan Pasal 5 ayat (1) b UU No. 20 Tahun 2001 jo UU No. 31 Tahun 1999}

Memberi sesuatu kepada pegawai negeri atau penyelenggara negara yang berhubungan dengan sesuatu yang bertentangan dengan kewajiban, dilakukan atau tidak dilakukan dalam jabatannya.

Memberi atau menjanjikan sesuatu merujuk pada pengertian gratifikasi dalam penjelasan Pasal 12b yaitu pemberian dalam arti luas, meliputi pemberian uang, barang, rabat (diskon), komisi, pinjaman tanpa bunga, tiket perjalanan, fasilitas penginapan, perjalanan wisata, pengobatan cuma-cuma, dan fasilitas lainnya. Gratifikasi diterima baik di dalam maupun di luar negeri dan yang dilakukan dengan menggunakan sarana elektronik atau tanpa sarana elektronik. Selanjutnya pengertian janji yaitu pemberian harapan untuk memberikan gratifikasi pada waktu tertentu dan dengan syarat tertentu. 
Pegawai negeri atau penyelenggara negara menurut UU tentang Kepegawaian adalah:

a. Pegawai negeri sebagaimana dimaksud dalam Kitab Undang-undang Hukum Pidana;

b. Orang yang menerima gaji atau upah dari keuangan negara atau daerah;

c. Orang yang menerima gaji atau upah dari suatu korporasi yang menerima bantuan dari keuangan negara atau daerah; atau

d. Orang yang menerima gaji atau upah dari korporasi lain yang menggunakan modal atau fasilitas dari negara atau masyarakat.

Sedangkan yang dimaksud dengan penyelenggara negara dalam Pasal 2 UU No. 28 Tahun 1999 meliputi pejabat negara pada lembaga tertinggi negara, pejabat negara pada lembaga tinggi negara, menteri, gubernur, hakim, pejabat negara lain berdasarkan peraturan perundang-undangan, serta pejabat negara lain yang memiliki fungsi strategis.

Dengan maksud berarti sesuatu perbuatan yang dilakukan oleh pelakunya harus diketahui, dikehendaki dan disadari akan akibatnya.

Berhubungan dengan sesuatu yang bertentangan dengan kewajiban, dilakukan atau tidak dilakukan dalam jabatannya berarti bahwa pemberian telah dilakukan dan perbuatan yang diinginkan oleh si pemberi sudah dilakukan oleh pegawai negeri atau penyelenggara negara, sehingga pemberian itu merupakan imbalan dari perbuatan tersebut (Sukardi 2009).

\section{e. Unsur-unsur Tindak Pidana Korupsi dan Pengertiannya sesuai dengan Pasal 5 ayat (2) UU No. 20 Tahun 2001 jo UU No. 31 Tahun 1999}

Pegawai negeri atau penyelenggara negara menerima pemberian atau janji.

Pegawai negeri atau penyelenggara negara adalah:

a. Pegawai negeri sebagaimana undang-undang tentang Kepegawaian;

b. Pegawai negeri sebagaimana dimaksud dalam Kitab Undang-Undang Hukum Pidana;

c. Orang yang menerima gaji atau upah dari keuangan negara atau daerah;

d. Orang yang menerima gaji atau upah dari suatu korporasi yang menerima bantuan dari keuangan negara atau daerah; atau

e. Orang yang menerima gaji atau upah dari korporasi lain yang menggunakan modal atau fasilitas dari negara atau masyarakat

Sedangkan yang dimaksud dengan penyelenggara negara dalam Pasal 2 UU No. 28 Tahun 1999 tentang Penyelenggaraan Negara yang Bersih dan Bebas dari Korupsi, Kolusi dan Nepotisme disebutkan meliputi pejabat negara pada lembaga tertinggi negara, pejabat negara pada lembaga tinggi negara, menteri, gubernur, hakim, pejabat negara lain berdasarkan peraturan perundang-undangan, serta pejabat negara lain yang memiliki fungsi strategis. 
Menerima pemberian atau janji merujuk pada pengertian gratifikasi dalam penjelasan Pasal 12 b yaitu pemberian dalam arti luas, meliputi pemberian uang, barang, rabat (diskon), komisi, pinjaman tanpa bunga, tiket perjalanan, fasilitas penginapan, perjalanan wisata, pengobatan cuma-cuma, dan fasilitas lainnya. Gratifikasi dapat diterima baik di dalam maupun di luar negeri dan dilakukan dengan menggunakan sarana elektronik atau tanpa sarana elektronik. Selanjutnya pengertian janji adalah pemberian harapan untuk memberikan gratifikasi pada waktu tertentu dan dengan syarat tertentu.

\section{f. Unsur-Unsur Tindak Pidana Korupsi dan Pengertiannya sesuai dengan Pasal 8 UU No. 20 Tahun 2001 jo UU No. 31 Tahun 1999}

Pegawai negeri atau orang selain pegawai negeri yang ditugaskan menjalankan suatu jabatan umum secara terus menerus atau untuk sementara waktu, dengan sengaja menggelapkan uang atau surat berharga yang disimpan karena jabatannya, atau membiarkan uang atau surat berharga tersebut diambil atau digelapkan oleh orang lain, atau membantu dalam melakukan perbuatan tersebut.

\section{Pegawai negeri atau penyelenggara negara adalah:}

a. Pegawai negeri sebagaimana undang-undang tentang Kepegawaian;

b. Pegawai negeri sebagaimana dimaksud dalam Kitab Undang-undang Hukum Pidana;

c. Orang yang menerima gaji atau upah dari keuangan negara atau daerah;

d. Orang yang menerima gaji atau upah dari suatu korporasi yang menerima bantuan dari keuangan negara atau daerah; atau

e. Orang yang menerima gaji atau upah dari korporasi lain yang menggunakan modal atau fasilitas dari negara atau masyarakat.

Sedangkan yang dimaksud dengan penyelenggara negara dalam Pasal 2 UU No. 28 Tahun 1999 Penyelenggaraan Negara Yang Bersih dan Bebas dari Korupsi, Kolusi dan Nepotisme disebutkan meliputi pejabat negara pada lembaga tertinggi negara, pejabat negara pada lembaga tinggi negara, menteri, gubernur, hakim, pejabat negara lain berdasarkan peraturan perundang-undangan, serta pejabat negara lain yang memiliki fungsi strategis.

Orang selain pegawai negeri adalah orang perseorangan atau termasuk korporasi.

\section{Ditugaskan menjalankan suatu jabatan umum secara terus menerus atau untuk sementara waktu adalah yang melalui Surat Keputusan pengangkatan atau surat keterangan lainnya, untuk suatu jabatan tertentu, dengan waktu terus-menerus atau hanya untuk sementara waktu.}

Dengan sengaja berarti perbuatan yang dilakukan oleh pelakunya harus diketahui, dikehendaki dan disadari akan akibatnya. 
Menggelapkan uang atau surat berharga yang disimpan karena jabatannya, atau membiarkan uang atau surat berharga tersebut diambil atau digelapkan oleh orang lain menurut Pasal 372 KUHP tentang penggelapan yaitu dengan sengaja dan dengan melawan hukum memiliki barang yang seluruhnya atau sebagian adalah kepunyaan orang lain, tetapi berada dalam kekuasaannya bukan karena tindak kejahatan.

Membantu dalam melakukan perbuatan sebagaimana dimaksud dalam Pasal 56 KUHP yaitu orang yang dipidana karena membantu melakukan kejahatan karena: (1) dengan sengaja memberi bantuan pada waktu kejahatan itu dilakukan; dan (2) dengan sengaja memberi kesempatan, sarana atau keterangan untuk melakukan kejahatan itu.

\section{g. Unsur-Unsur Tindak Pidana Korupsi dan Pengertiannya sesuai dengan Pasal 9} UU No. 20 Tahun 2001 jo UU No. 31 Tahun 1999

Pegawai negeri atau orang selain pegawai negeri yang diberi tugas menjalankan suatu jabatan umum secara terus menerus atau untuk sementara waktu dan dengan sengaja memalsu buku-buku atau daftar-daftar yang khusus untuk pemeriksaan administrasi.

Pegawai negeri atau penyelenggara negara adalah:

a. Pegawai negeri sebagaimana undang-undang tentang Kepegawaian;

b. Pegawai negeri sebagaimana dimaksud dalam Kitab Undang-undang Hukum Pidana;

c. Orang yang menerima gaji atau upah dari keuangan negara atau daerah;

d. Orang yang menerima gaji atau upah dari suatu korporasi yang menerima bantuan dari keuangan negara atau daerah; atau

e. Orang yang menerima gaji atau upah dari korporasi lain yang menggunakan modal atau fasilitas dari negara atau masyarakat.

Sedangkan yang dimaksud dengan penyelenggara negara dalam Pasal 2 UU No. 28 Tahun 1999 Penyelenggaraan Negara Yang Bersih dan Bebas dari Korupsi, Kolusi dan Nepotisme disebutkan meliputi pejabat negara pada lembaga tertinggi negara, pejabat negara pada lembaga tinggi negara, menteri, gubernur, hakim, pejabat negara lain berdasarkan peraturan perundang-undangan, serta pejabat negara lain yang memiliki fungsi strategis.

Diberi tugas menjalankan suatu jabatan umum secara terus menerus atau untuk sementara waktu adalah yang melalui Surat Keputusan pengangkatan atau surat keterangan lainnya, untuk suatu jabatan tertentu, dengan waktu terus-menerus atau hanya untuk sementara waktu.

Dengan sengaja maksudnya adalah perbuatan yang dilakukan oleh pelakunya harus diketahui, dikehendaki dan disadari akan akibatnya.

Memalsu buku-buku atau daftar-daftar yang khusus untuk pemeriksaan administrasi maksudnya adalah membuat buku-buku atau daftar-daftar yang seakan- 
akan adalah yang asli. Menurut Putusan Hoge Raad tanggal 15 Juni 1931, dinyatakan bahwa suatu tulisan itu yang dianggap palsu jika menimbulkan kesan seolah-olah telah dibuat oleh orang yang tandatangannya terdapat di bawahnya (Sukardi 2009).

\section{h. Unsur-unsur Tindak Pidana Korupsi dan Pengertiannya sesuai dengan Pasal 10 angka a UU No. 20 Tahun 2001 jo UU No. 31 Tahun 1999}

Pegawai negeri atau orang selain pegawai negeri yang diberi tugas menjalankan suatu jabatan umum secara terus-menerus atau untuk sementara waktu dengan sengaja menggelapkan, menghancurkan, merusakkan, atau membuat tidak dapat dipakai barang, akta, surat, atau daftar yang digunakan untuk meyakinkan atau membuktikan di muka pejabat yang berwenang, yang dikuasai karena jabatannya.

\section{Pegawai negeri atau penyelenggara negara adalah:}

a. Pegawai negeri sebagaimana Undang-Undang tentang Kepegawaian;

b. Pegawai negeri sebagaimana dimaksud dalam Kitab Undang-Undang Hukum Pidana;

c. Orang yang menerima gaji atau upah dari keuangan negara atau daerah;

d. Orang yang menerima gaji atau upah dari suatu korporasi yang menerima bantuan dari keuangan negara atau daerah; atau

e. Orang yang menerima gaji atau upah dari korporasi lain yang mempergunakan modal atau fasilitas dari negara atau masyarakat

Sedangkan yang dimaksud dengan penyelenggara negara dalam Pasal 2 UU No. 28 Tahun 1999 Penyelenggaraan Negara Yang Bersih dan Bebas dari Korupsi, Kolusi dan Nepotisme disebutkan meliputi pejabat negara pada lembaga tertinggi negara, pejabat negara pada lembaga tinggi negara, menteri, gubernur, hakim, pejabat negara lain berdasarkan peraturan perundang-undangan, serta pejabat negara lain yang memiliki fungsi strategis.

Orang selain pegawai negeri adalah orang perseorangan atau termasuk korporasi.

\section{Diberi tugas menjalankan suatu jabatan umum secara terus menerus atau untuk} sementara waktu adalah yang melalui Surat Keputusan pengangkatan atau surat keterangan lainnya, untuk suatu jabatan tertentu, dengan waktu terus-menerus atau ditentukan hanya untuk sementara waktu.

Dengan sengaja adalah suatu perbuatan yang dilakukan oleh pelakunya harus diketahui, dikehendaki dan disadari akan akibatnya.

\section{Menggelapkan, menghancurkan, merusakkan, atau membuat tidak dapat dipakai barang, akta, surat, atau daftar yang digunakan untuk meyakinkan atau membuktikan di muka pejabat yang berwenang, yang dikuasai karena jabatannya adalah membuat barang, akta, surat atau daftar tersebut, tidak mempunyai nilai kekuatan pembuktian di hadapan pejabat yang berwenang.}




\section{i. Unsur-unsur Tindak Pidana Korupsi dan Pengertiannya sesuai dengan Pasal 10 angka b UU No. 20 Tahun 2001 jo UU No. 31 Tahun 1999 \\ Membiarkan orang lain menghilangkan, menghancurkan, merusakkan, atau membuat tidak dapat dipakai barang, akta, surat, atau daftar tersebut.}

Membiarkan orang lain sebagaimana dimaksud dalam Pasal 56 KUHP yaitu mereka yang sengaja memberi bantuan pada waktu kejahatan dilakukan; atau mereka yang sengaja memberi kesempatan, sarana atau keterangan untuk melakukan kejahatan itu.

Menghilangkan, menghancurkan, merusakkan, atau membuat tidak dapat dipakai barang, akta, surat, atau daftar tersebut adalah secara sengaja membuat barang, akta, surat atau daftar tersebut, sehingga tidak dapat digunakan lagi sebagaimana mestinya.

\section{j. Unsur-unsur Tindak Pidana Korupsi dan Pengertiannya sesuai dengan Pasal 10 angka c UU No. 20 Tahun 2001 jo UU No. 31 Tahun 1999}

Membantu orang lain menghilangkan, menghancurkan, merusakkan, atau membuat tidak dapat dipakai barang, akta, surat, atau daftar tersebut.

Membantu orang lain sebagaimana dimaksud dalam Pasal 56 KUHP yaitu mereka yang dipidana sebagai orang yang membantu melakukan kejahatan karena: (1) sengaja memberi bantuan pada waktu kejahatan itu dilakukan; dan (2) sengaja memberi kesempatan, sarana atau keterangan untuk melakukan kejahatan itu.

Menghilangkan, menghancurkan, merusakkan, atau membuat tidak dapat dipakai barang, akta, surat, atau daftar tersebut artinya sengaja membuat barang, akta, surat atau daftar tersebut, sehingga tidak dapat digunakan lagi sebagaimana mestinya.

\section{k. Unsur-unsur Tindak Pidana Korupsi dan pengertiannya sesuai dengan Pasal 11 UU No. 20 Tahun 2001 jo UU No. 31 Tahun 1999}

\footnotetext{
Pegawai negeri atau penyelenggara negara yang menerima hadiah atau janji padahal diketahui atau patut diduga bahwa hadiah atau janji tersebut diberikan karena kekuasaan atau kewenangan yang berhubungan dengan jabatannya atau yang menurut pikiran orang yang memberikan hadiah atau janji tersebut ada hubungan dengan jabatannya.
}

Pegawai negeri atau penyelenggara negara adalah:

a. Pegawai negeri sebagaimana undang-undang tentang Kepegawaian;

b. Pegawai negeri sebagaimana dimaksud dalam Kitab Undang-undang Hukum Pidana;

c. Orang yang menerima gaji atau upah dari keuangan negara atau daerah;

d. Orang yang menerima gaji atau upah dari suatu korporasi yang menerima bantuan dari keuangan negara atau daerah; atau 
e. Orang yang menerima gaji atau upah dari korporasi lain yang menggunakan modal atau fasilitas dari negara atau masyarakat

Sedangkan yang dimaksud dengan penyelenggara negara dalam Pasal 2 UU No. 28 Tahun 1999 Penyelenggaraan Negara Yang Bersih dan Bebas dari Korupsi, Kolusi dan Nepotisme disebutkan meliputi pejabat negara pada lembaga tertinggi negara, pejabat negara pada lembaga tinggi negara, menteri, gubernur, hakim, pejabat negara lain berdasarkan peraturan perundang-undangan, serta pejabat negara lain yang memiliki fungsi strategis.

Menerima hadiah atau janji. Putusan Hoge Raad tanggal 25 April 1916 menyebutkan bahwa yang dimaksud dengan hadiah adalah segala sesuatu yang mempunyai nilai. Sedangkan yang dimaksud dengan janji adalah tawaran sesuatu yang diajukan dan akan dipenuhi oleh si pemberi tawaran (Sukardi 2009).

Unsur ini merujuk pada pengertian gratifikasi dalam penjelasan Pasal $12 \mathrm{~b}$ yaitu pemberian dalam arti luas, meliputi pemberian uang, barang, rabat (diskon), komisi, pinjaman tanpa bunga, tiket perjalanan, fasilitas penginapan, perjalanan wisata, pengobatan cuma-cuma, dan fasilitas lainnya. Gratifikasi ini diterima baik di dalam maupun di luar negeri dan yang dilakukan dengan menggunakan sarana elektronik atau tanpa sarana elektronik. Selanjutnya pengertian janji yaitu pemberian harapan untuk memberikan gratifikasi pada waktu tertentu dan dengan syarat tertentu.

\section{Padahal diketahui atau patut diduga bahwa hadiah atau janji tersebut diberikan karena kekuasaan atau kewenangan yang berhubungan dengan jabatannya atau yang menurut pikiran orang yang memberikan hadiah atau janji tersebut ada hubungan dengan jabatannya berarti bahwa harus melihat adanya hubungan/ keterkaitan antara pemberian dengan jabatan/kekuasaan/kewenangan dari orang yang menerima, apakah ada harapan/kemungkinan timbal-balik. Dari rumusan ini jelas terlihat bahwa bentuk kesalahan pelaku dalam Pasal 11 ini adalah dolus atau culpa, sehingga Pasal 11 ini dapat dikatakan bersifat pro parte dolus pro parte culpa (Sukardi 2009).}

\section{Unsur-unsur Tindak Pidana Korupsi dan Pengertiannya sesuai dengan Pasal 12 angka a UU No. 20 Tahun 2001 jo UU No. 31 Tahun 1999}

Pegawai negeri atau penyelenggara negara yang menerima hadiah atau janji, padahal diketahui atau patut diduga bahwa hadiah atau janji tersebut diberikan untuk menggerakkan agar melakukan atau tidak melakukan sesuatu dalam jabatannya, yang bertentangan dengan kewajibannya.

\section{Pegawai negeri atau penyelenggara negara yaitu:}

a. pegawai negeri sebagaimana undang-undang tentang Kepegawaian;

b. pegawai negeri sebagaimana dimaksud dalam Kitab Undang-undang Hukum Pidana;

c. orang yang menerima gaji atau upah dari keuangan negara atau daerah; 
d. orang yang menerima gaji atau upah dari suatu korporasi yang menerima bantuan dari keuangan negara atau daerah; atau

e. orang yang menerima gaji atau upah dari korporasi lain yang mempergunakan modal atau fasilitas dari negara atau masyarakat

Sedangkan yang dimaksud dengan penyelenggara negara dalam Pasal 2 UU Nomor 28 Tahun 1999, Penyelenggaraan Negara yang Bersih dan Bebas dari Korupsi, Kolusi dan Nepotisme disebutkan meliputi pejabat negara pada lembaga tertinggi negara, pejabat negara pada lembaga tinggi negara, menteri, gubernur, hakim, pejabat negara lain berdasarkan peraturan perundang-undangan, serta pejabat negara lain yang memiliki fungsi strategis.

Menerima hadiah atau janji menurut putusan Hoge Raad tanggal 25 April 1916 menyebutkan bahwa yang dimaksud dengan hadiah adalah segala sesuatu yang mempunyai nilai. Sedangkan yang dimaksud dengan janji adalah tawaran sesuatu yang diajukan dan akan dipenuhi oleh si pemberi tawaran (Sukardi 2009).

Menerima hadiah atau janji merujuk pada pengertian gratifikasi dalam penjelasan Pasal $12 \mathrm{~b}$ yaitu pemberian dalam arti luas, meliputi pemberian uang, barang, rabat (diskon), komisi, pinjaman tanpa bunga, tiket perjalanan, fasilitas penginapan, perjalanan wisata, pengobatan cuma-cuma, dan fasilitas lainnya. Gratifikasi tersebut diterima baik di dalam maupun di luar negeri dan yang dilakukan dengan menggunakan sarana elektronik atau tanpa sarana elektronik. Selanjutnya pengertian janji yaitu pemberian harapan untuk memberikan gratifikasi pada waktu tertentu dan dengan syarat tertentu.

\section{Padahal diketahui atau patut diduga bahwa hadiah atau janji tersebut diberikan untuk menggerakkan agar melakukan atau tidak melakukan sesuatu dalam jabatannya, yang bertentangan dengan kewajibannya}

Supaya pegawai negeri atau penyelenggara negara tersebut melakukan atau tidak melakukan sesuatu dalam jabatannya bahwa pemberian atau janji untuk memberikan sesuatu itu dimaksudkan agar pegawai negeri atau penyelenggara negara itu melakukan sesuatu perbuatan untuk kepentingan si pemberi atau orang lain yang menjanjikan. Pemberian atau janji itu telah diberikan, tapi perbuatan yang diinginkan oleh si pemberi belum dilaksanakan oleh pegawai negeri namun sudah ketahuan atau tertangkap lebih dulu. ${ }^{16}$

\section{m. Unsur-Unsur Tindak Pidana Korupsi dan Pengertiannya sesuai dengan Pasal} 12 angka b UU No. 20 Tahun 2001 jo UU No. 31 Tahun 1999

\footnotetext{
Pegawai negeri atau penyelenggara negara yang menerima hadiah, padahal diketahui atau patut diduga bahwa hadiah tersebut diberikan sebagai akibat atau disebabkan karena telah melakukan atau tidak melakukan sesuatu dalam jabatannya yang bertentangan dengan kewajibannya.
}

16 Perbuatan pidana yang di dalamnya mencakup unsur kesengajaan dan kelalaian. 


\section{Pegawai negeri atau penyelenggara negara yaitu:}

a. pegawai negeri sebagaimana undang-undang tentang Kepegawaian;

b. pegawai negeri sebagaimana dimaksud dalam Kitab Undang-undang Hukum Pidana;

c. orang yang menerima gaji atau upah dari keuangan negara atau daerah;

d. orang yang menerima gaji atau upah dari suatu korporasi yang menerima bantuan dari keuangan negara atau daerah; atau

e. orang yang menerima gaji atau upah dari korporasi lain yang mempergunakan modal atau fasilitas dari negara atau masyarakat

Sedangkan yang dimaksud dengan penyelenggara negara dalam Pasal 2 UU Nomor 28 Tahun 1999 Penyelenggaraan Negara Yang Bersih dan Bebas dari Korupsi, Kolusi dan Nepotisme disebutkan meliputi pejabat negara pada lembaga tertinggi negara, pejabat negara pada lembaga tinggi negara, menteri, gubernur, hakim, pejabat negara lain berdasarkan peraturan perundang-undangan, serta pejabat negara lain yang memiliki fungsi strategis.

Menerima hadiah menurut putusan Hoge Raad tanggal 25 April 1916 menyebutkan bahwa yang dimaksud dengan hadiah adalah segala sesuatu yang mempunyai nilai. Sedangkan yang dimaksud dengan janji adalah tawaran sesatu yang diajukan dan akan dipenuhi oleh si pemberi tawaran (Sukardi 2009).

Menerima hadiah merujuk pada pengertian gratifikasi dalam penjelasan Pasal $12 \mathrm{~b}$ yaitu pemberian dalam arti luas, yakni meliputi pemberian uang, barang, rabat (diskon), komisi, pinjaman tanpa bunga, tiket perjalanan, fasilitas penginapan, perjalanan wisata, pengobatan cuma-cuma, dan fasilitas lainnya. Gratifikasi tersebut diterima baik di dalam maupun di luar negeri dan yang dilakukan dengan menggunakan sarana elektronik atau tanpa sarana elektronik. Selanjutnya pengertian janji yaitu pemberian harapan untuk memberikan gratifikasi pada waktu tertentu dan dengan syarat tertentu.

\section{Padahal diketahui atau patut diduga bahwa hadiah tersebut diberikan sebagai akibat atau disebabkan karena telah melakukan atau tidak melakukan sesuatu dalam jabatannya yang bertentangan dengan kewajibannya}

Supaya pegawai negeri atau penyelenggara negara tersebut melakukan atau tidak melakukan sesuatu dalam jabatannya bahwa pemberian atau janji untuk memberikan sesuatu itu dimaksudkan agar pegawai negeri atau penyelenggara negara itu melakukan sesuatu perbuatan untuk kepentingan si pemberi atau orang lain yang menjanjikan. Sehingga pemberian atau janji itu telah diberikan, tapi perbuatan yang diinginkan oleh si pemberi belum dilaksanakan oleh pegawai negeri, namun sudah ketahuan atau tertangkap lebih dulu. 


\title{
n. Unsur-Unsur Tindak Pidana Korupsi dan Pengertiannya sesuai dengan Pasal 12 angka e UU No. 20 Tahun 2001 jo UU No. 31 Tahun 1999
}

\begin{abstract}
Pegawai negeri atau penyelenggara negara yang dengan maksud menguntungkan diri sendiri atau orang lain secara melawan hukum atau dengan menyalahgunakan kekuasaannya memaksa seseorang memberikan sesuatu, membayar, atau menerima pembayaran dengan potongan, atau untuk mengerjakan sesuatu bagi dirinya sendiri.
\end{abstract}

Pegawai negeri atau penyelenggara negara yaitu:

a. pegawai negeri sebagaimana undang-undang tentang Kepegawaian;

b. pegawai negeri sebagaimana dimaksud dalam Kitab Undang-undang Hukum Pidana;

c. orang yang menerima gaji atau upah dari keuangan negara atau daerah;

d. orang yang menerima gaji atau upah dari suatu korporasi yang menerima bantuan dari keuangan negara atau daerah; atau

e. orang yang menerima gaji atau upah dari korporasi lain yang mempergunakan modal atau fasilitas dari negara atau masyarakat

Sedangkan yang dimaksud dengan penyelenggara negara dalam Pasal 2 UU Nomor 28 Tahun 1999 Penyelenggaraan Negara Yang Bersih dan Bebas dari Korupsi, Kolusi dan Nepotisme disebutkan meliputi pejabat negara pada lembaga tertinggi negara, pejabat negara pada lembaga tinggi negara, menteri, gubernur, hakim, pejabat negara lain berdasarkan peraturan perundang-undangan, serta pejabat negara lain yang memiliki fungsi strategis.

Menguntungkan diri sendiri atau orang lain berarti melakukan perbuatan menguntungkan diri sendiri atau orang lain dengan mengumpulkan kekayaan yang tidak seimbang dengan penghasilannya atau penambahan kekayaan dari sumber yang tidak sah (Sukardi 2009).

Melawan hukum berarti tanpa hak sendiri atau bertentangan dengan hak orang lain atau tanpa alasan yang wajar, atau bertentangan dengan hukum positif.

Menyalahgunakan kekuasaannya adalah melakukan sesuatu yang bertentangan dengan kewajiban dalam jabatannya.

\footnotetext{
Memaksa seseorang memberikan sesuatu, membayar, atau menerima pembayaran dengan potongan, atau untuk mengerjakan sesuatu bagi dirinya sendiri adalah membuat atau menyuruh orang lain dengan kekerasan/ancaman sehingga seseorang tersebut melakukan sesuatu namun tidak sesuai dengan kehendak nuraninya.
}

\section{o. Unsur-unsur Tindak Pidana Korupsi dan Pengertiannya sesuai dengan Pasal 12 b ayat (1) UU No. 20 Tahun 2001 jo UU No. 31 Tahun1999}

... gratifikasi pegawai negeri atau penyelenggara negara ... dianggap pemberian suap, apabila berhubungan dengan jabatannya dan yang berlawanan dengan kewajiban atau tugasnya. 
Gratifikasi yaitu pemberian dalam arti luas, meliputi pemberian uang, barang, rabat (diskon), komisi, pinjaman tanpa bunga, tiket perjalanan, fasilitas penginapan, perjalanan wisata, pengobatan cuma-cuma, dan fasilitas lainnya. Gratifikasi tersebut baik yang diterima di dalam negeri maupun di luar negeri dan yang dilakukan dengan menggunakan sarana elektronik atau tanpa sarana elektronik (berdasarkan penjelasan Pasal 12b).

\section{Apa yang dimaksud dengan unsur 'pegawai negeri atau penyelenggara Negara'? pegawai negeri atau penyelenggara negara yaitu:}

a. Pegawai negeri sebagaimana undang-undang tentang Kepegawaian;

b. Pegawai negeri sebagaimana dimaksud dalam Kitab Undang-undang Hukum Pidana;

c. Orang yang menerima gaji atau upah dari keuangan negara atau daerah;

d. Orang yang menerima gaji atau upah dari suatu korporasi yang menerima bantuan dari keuangan negara atau daerah; atau

e. Orang yang menerima gaji atau upah dari korporasi lain yang mempergunakan modal atau fasilitas dari negara atau masyarakat

Sedangkan yang dimaksud dengan penyelenggara negara dalam Pasal 2 UU No. 28 Tahun 1999 Penyelenggaraan Negara Yang Bersih dan Bebas dari Korupsi, Kolusi dan Nepotisme disebutkan meliputi pejabat negara pada lembaga tertinggi negara, pejabat negara pada lembaga tinggi negara, menteri, gubernur, hakim, pejabat negara lain berdasarkan peraturan perundang-undangan, serta pejabat negara lain yang memiliki fungsi strategis.

\section{Dianggap pemberian suap, apabila berhubungan dengan jabatannya dan yang berlawanan dengan kewajiban atau tugasnya yaitu melakukan sesuatu akibat gratifikasi tersebut, namun bertentangan dengan kewajiban dalam jabatannya.}

\section{p. Unsur-Unsur Tindak Pidana Korupsi dan Pengertiannya sesuai dengan Pasal 13 UU No. 20 Tahun 2001 jo UU No. 31 Tahun1999}

\footnotetext{
Setiap orang yang memberi hadiah atau janji kepada pegawai negeri dengan mengingat kekuasaan atau wewenang yang melekat pada jabatan atau kedudukannya, atau oleh pemberi hadiah atau janji dianggap melekat pada jabatan atau kedudukan tersebut.
}

Setiap orang adalah orang perseorangan atau termasuk korporasi (berdasarkan Pasal 1 angka 3).

\section{Apa yang dimaksud dengan unsur 'memberi hadiah atau janji'?}

Putusan Hoge Raad tanggal 25 April 1916 menyebutkan bahwa yang dimaksud dengan hadiah adalah segala sesuatu yang mempunyai nilai (Sukardi 2009).

Sedangkan yang dimaksud dengan janji adalah tawaran sesuatu yang diajukan dan akan dipenuhi oleh si pemberi tawaran. 
Memberi hadiah atau janji merujuk pada pengertian gratifikasi dalam penjelasan Pasal 12b yaitu pemberian dalam arti luas, yakni meliputi pemberian uang, barang, rabat (diskon), komisi, pinjaman tanpa bunga, tiket perjalanan, fasilitas penginapan, perjalanan wisata, pengobatan cuma-cuma, dan fasilitas lainnya. Gratifikasi tersebut baik yang diterima di dalam negeri maupun di luar negeri dan yang dilakukan dengan menggunakan sarana elektronik atau tanpa sarana elektronik. Selanjutnya pengertian janji yaitu pemberian harapan untuk memberikan gratifikasi pada waktu tertentu dan dengan syarat tertentu.

\section{Apa yang dimaksud dengan unsur 'kepada pegawai negeri atau penyelenggara Negara'?}

\section{Kepada pegawai negeri atau penyelenggara negara yaitu:}

a. pegawai negeri sebagaimana undang-undang tentang Kepegawaian;

b. pegawai negeri sebagaimana dimaksud dalam Kitab Undang-undang Hukum Pidana;

c. orang yang menerima gaji atau upah dari keuangan negara atau daerah;

d. orang yang menerima gaji atau upah dari suatu korporasi yang menerima bantuan dari keuangan negara atau daerah; atau

f. orang yang menerima gaji atau upah dari korporasi lain yang mempergunakan modal; atau

g. fasilitas dari negara atau masyarakat

Sedangkan yang dimaksud dengan penyelenggara negara dalam Pasal 2 UU Nomor 28 Tahun 1999 Penyelenggaraan Negara Yang Bersih dan Bebas dari Korupsi, Kolusi dan Nepotisme disebutkan meliputi pejabat negara pada lembaga tertinggi negara, pejabat negara pada lembaga tinggi negara, menteri, gubernur, hakim, pejabat negara lain berdasarkan peraturan perundang-undangan, serta pejabat negara lain yang memiliki fungsi strategis.

\section{Mengingat kekuasaan atau wewenang yang melekat pada jabatan atau} kedudukannya, atau oleh pemberi hadiah atau janji dianggap melekat pada jabatan atau kedudukan tersebut. Pemberian atau janji untuk memberikan sesuatu itu dimaksudkan agar pegawai negeri atau_penyelenggara negara itu melakukan sesuatu perbuatan untuk kepentingan si pemberi atau orang lain yang menjanjikan. Pemberian atau janji itu telah diberikan, tapi perbuatan yang diinginkan oleh si pemberi belum dilaksanakan oleh pegawai negeri, namun sudah ketahuan atau tertangkap lebih dulu. Pelaku tindak pidana dalam Pasal 13 ini tidak disyaratkan harus mempunyai maksud, tetapi cukup jika dia mengetahui dengan jelas apa yang menjadi kekuasaan atau wewenang yang melekat pada pegawai negeri atau penyelenggara negara tersebut.

\section{q. Unsur-unsur Tindak Pidana Korupsi dan Pengertiannya sesuai dengan Pasal 15} UU No. 20 Tahun 2001 jo UU No. 31 Tahun 1999

Setiap orang yang melakukan percobaan, pembantuan, atau permufakatan jahat untuk melakukan tindak pidana korupsi. 
Setiap orang adalah orang perseorangan atau termasuk korporasi (berdasarkan Pasal 1 angka 3).

Melakukan percobaan sebagaimana dimaksud dalam Pasal 53 KUHP yaitu bila niat untuk itu telah ternyata dari adanya permulaan pelaksanaan, dan tidak-selesainya pelaksanaan itu bukan semata-mata disebabkan oleh kemauannya sendiri.

Pembantuan sebagaimana dimaksud dalam Pasal 56 KUHP yaitu orang yang dipidana sebagai karena membantu melakukan kejahatan adalah mereka yang (1) dengan sengaja memberi bantuan pada waktu kejahatan itu dilakukan; dan (2) dengan sengaja memberi kesempatan, sarana atau keterangan untuk melakukan kejahatan itu.

Permufakatan jahat sebagaimana dimaksud dalam Pasal 88 KUHP yaitu bila dua orang atau lebih telah sepakat untuk melakukan kejahatan.

Untuk melihat lebih jelas mengenai penerapan pasal-pasal tindak pidana korupsi di atas terhadap kejahatan kehutanan, dapat dilihat dalam uraian Bab 5.

\subsection{Tindak Pidana Pencucian Uang}

Pencucian uang melibatkan aset (pendapatan atau kekayaan) yang disamarkan sehingga dapat digunakan tanpa terdeteksi bahwa sumbernya adalah kegiatan ilegal. Melalui pencucian ini pendapatan atau kekayaan yang berasal dari kegiatan yang melawan hukum diubah menjadi aset keuangan yang seolah-olah berasal dari sumber yang sah/legal (Husein 2007).

Unsur-unsur pokok dalam proses pencucian uang disajikan dalam Gambar 3.

Secara umum ada tiga tahapan pencucian uang yang dilakukan melalui lembagalembaga keuangan khususnya perbankan, usaha real estate, dan penukaran uang (Husein 2007). Ketiga tahap ini adalah (BPK 2008):

a. Tahap penempatan (placement), merupakan tahap pengumpulan dan penempatan uang hasil kejahatan di suatu bank atau tempat tertentu yang diperkirakan aman guna mengubah bentuk uang tersebut agar tidak teridentifikasi. Biasanya dana yang ditempatkan berupa uang tunai dalam jumlah besar yang dibagi ke dalam jumlah yang lebih kecil dan ditempatkan di beberapa rekening di beberapa tempat;

b. Tahap pelapisan (layering), merupakan upaya untuk mengurangi jejak asal uang tersebut atau ciri-ciri asli dari uang hasil kejahatan tersebut atau nama pemilik uang hasil tindak pidana, dengan melibatkan tempat-tempat atau bank di negaranegara dimana kerahasiaan bank akan menyulitkan pelacakan jejak uang. Tindakan ini dapat berupa transfer dana ke negara lain dalam bentuk mata uang asing, pembelian properti, pembelian saham pada bursa efek menggunakan deposit yang ada di bank A untuk meminjam uang di bank B dan sebagainya.

c. Tahap penggabungan (integration), merupakan tahap mengumpulkan dan menyatukan kembali uang hasil kejahatan yang telah melalui tahap pelapisan 
dalam suatu proses arus keuangan yang sah. Pada tahap ini uang hasil kejahatan benar-benar telah bersih dan sulit dikenali sebagai hasil tindak pidana, dan muncul kembali sebagai aset atau investasi yang tampaknya legal.

Selain itu, ada empat cara umum atau tipologi yang digunakan dalam pencucian uang (BPK 2008):

\section{a. Tipologi dasar}

1. Modus orang ketiga, yaitu dengan menggunakan seseorang untuk menjalankan perbuatan tertentu yang diinginkan oleh pelaku pencurian uang, dengan menggunakan atau mengatasnamakan orang ketiga atau orang lain lagi yang berlainan. Ciri-cirinya orang ketiga adalah: hampir selalu nyata dan bukan hanya nama palsu dalam dokumen, biasanya menyadari bahwa ia dipergunakan, merupakan orang kepercayaan yang bisa dikendalikan, dan hubungannya dengan pelaku sangat dekat sehingga dapat berkomunikasi setiap saat.

2. Modus topeng usaha sederhana, merupakan kelanjutan modus orang ketiga, yang kemudian akan diperintahkan untuk mendirikan suatu bidang usaha dengan menggunakan kekayaan yang merupakan hasil tindak pidana.

3. Modus perbankan sederhana, dapat merupakan kelanjutan modus pertama dan kedua, namun juga dapat berdiri sendiri. Di sini terjadi perpindahan sistem transaksi tunai yang berubah dalam bentuk cek kontan, cek perjalanan, atau bentuk lain dalam deposito, tabungan yang dapat ditransfer dengan cepat dan digunakan lagi dalam pembelian aset-aset. Modus ini banyak meninggalkan jejak melalui dokumen rekening koran, cek, dan data lain yang mengarah pada nasabah itu, serta keluar masuknya dari proses transaksi baik yang menuju ke seseorang maupun ke aset-aset, atau ke pembayaran-pembayaran lain.

4. Modus kombinasi perbankan atau usaha, yang dilakukan oleh orang ketiga yang menguasai suatu usaha dengan memasukkan uang hasil kejahatan ke bank untuk kemudian ditukar dengan cek yang kemudian digunakan untuk pembelian aset atau pendirian usaha-usaha lain.

\section{b. Tipologi ekonomi}

1. Model smurfing, yakni pelaku menggunakan sejumlah rekannya untuk memecah sejumlah besar uang tunai dalam beberapa jumlah kecil di bawah batas uang tunai sehingga bank tidak mencurigai kegiatan tersebut. Kemudian uang tunai ini ditukarkan di bank dengan cek perjalanan atau cek kontan. Bentuk lain adalah dengan memasukkan dalam rekening para smurfing di satu tempat pada suatu bank kemudian mengambil pada bank yang sama di kota yang berbeda atau disetorkan ke rekening-rekening pelaku pencucian uang di kota lain sehingga terkumpul dalam beberapa rekening pelaku pencucian uang. Rekening ini tidak langsung atas nama pelaku namun bisa menunjuk pada suatu perusahaan lain atau rekening lain yang disamarkan nama pemiliknya.

2. Model perusahaan rangka, disebut demikian karena perusahaan ini sebenarnya tidak menjalankan kegiatan usaha apapun, melainkan dibentuk agar rekening perusahaannya dapat digunakan untuk memindahkan sesuatu atau uang. Perusahaan rangka dapat digunakan untuk penempatan dana sementara sebelum dipindah atau digunakan lagi. Perusahaan rangka dapat terhubung satu dengan 
yang lain. Misalnya, saham 'PT A' dimiliki oleh 'PT B' yang berada di daerah atau negara lain, sementara saham 'PT B' sebagian dimiliki oleh 'PT A, PT B, PT C' dan/atau 'PT D' yang berada di daerah atau negara lain.

3. Modus pinjaman kembali, yaitu suatu variasi dari kombinasi modus perbankan dan modus usaha. Contohnya, pelaku pencucian uang menyerahkan uang hasil tindak pidana kepada A (orang ketiga), dan A memasukkan sebagian dana tersebut ke bank B dan sebagian dana juga didepositokan ke bank C. Selain itu a meminjam uang ke bank D. Dengan bunga deposito bank C, A kemudian membayar bunga dan pokok pinjamannya dari bank D. Dari segi jumlah memang terdapat kerugian karena harus membayar bunga pinjaman, namun uang ilegal tersebut telah berubah menjadi uang pinjaman yang bersih dengan dokumen yang lengkap.

4. Modus under invoicing, yaitu modus untuk memasukkan uang hasil tindak pidana dalam pembelian suatu barang yang nilai jualnya sebenarnya lebih besar daripada yang dicantumkan dalam faktur.

5. Modus over invoicing, merupakan kebalikan dari modus under invoicing.

Modus over invoicing, sebenarnya tidak melibatkan barang yang diperjualbelikan, tetapi menggunakan faktur yang dijadikan bukti pembelian (penjualan fiktif) sebab penjual dan pembeli sebenarnya adalah pelaku pencucian uang.

6. Modus pembelian kembali, yaitu pelaku pencucian uang menggunakan dana yang telah dicuci untuk membeli sesuatu yang telah ia miliki.

\section{c. Tipologi IT (Information Technology)}

1. Modus E-Bisnis, modusnya menyerupai Multi Level Marketing (MLM), namun menggunakan sarana internet.

2. Modus scanner merupakan tindak pidana pencucian uang dengan pidana asal berupa penipuan dan pemalsuan atas dokumen-dokumen transaksi keuangan.

\section{d. Tipologi hitek}

Merupakan suatu bentuk kejahatan yang skemanya terorganisir namun orang-orang kunci yang terlibat tidak saling mengenal, nilai uang relatif tidak besar tetapi bila dikumpulkan menimbulkan kerugian yang sangat besar. Cara ini dikenal dengan nama modus cleaning karena kejahatan ini biasanya dilakukan dengan menembus sistem database suatu bank.

Dalam perkembangannya, tindak pidana Pencucian Uang semakin kompleks, melintasi batas-batas yurisdiksi, dan menggunakan modus yang semakin variatif, memanfaatkan lembaga di luar sistem keuangan, bahkan telah merambah ke berbagai sektor. Untuk mengantisipasi hal itu, Financial Action Task Force (FATF) on Money Laundering telah mengeluarkan standar internasional yang menjadi ukuran bagi setiap negara dalam pencegahan dan pemberantasan tindak pidana Pencucian Uang dan tindak pidana pendanaan terorisme yang dikenal dengan Revised 40 Recommendations dan 9 Special Recommendations (Revised 40+9) FATF, antara lain mengenai perluasan Pihak Pelapor (reporting parties) yang mencakup pedagang permata dan perhiasan/logam mulia dan pedagang kendaraan bermotor (UU No. 8 Tahun 2010). 
Dalam mencegah dan memberantas tindak pidana Pencucian Uang perlu dilakukan kerja sama regional dan internasional melalui forum bilateral atau multilateral agar intensitas tindak pidana yang menghasilkan atau melibatkan Harta Kekayaan yang jumlahnya besar dapat diminimalisasi (UU No. 8 Tahun 2010).

Penanganan tindak pidana Pencucian Uang di Indonesia yang dimulai sejak disahkannya Undang-Undang Nomor 15 Tahun 2002 tentang Tindak Pidana Pencucian Uang sebagaimana telah diubah dengan Undang-Undang Nomor 25 Tahun 2003 tentang Perubahan atas Undang-Undang Nomor 15 Tahun 2002 tentang Tindak Pidana Pencucian Uang, telah menunjukkan arah yang positif. Hal itu, tercermin dari meningkatnya kesadaran dari pelaksana Undang-Undang tentang Tindak Pidana Pencucian Uang, seperti penyedia jasa keuangan dalam melaksanakan kewajiban pelaporan, Lembaga Pengawas dan Pengatur dalam pembuatan peraturan, Pusat Pelaporan dan Analisis Transaksi Keuangan (PPATK) dalam kegiatan analisis, dan penegak hukum dalam menindaklanjuti hasil analisis hingga penjatuhan sanksi pidana dan/atau sanksi administratif (UU No. 8 Tahun 2010).

Upaya yang dilakukan tersebut dirasakan belum optimal, antara lain karena peraturan perundang-undangan yang ada ternyata masih memberikan ruang timbulnya penafsiran yang berbeda-beda, adanya celah hukum, kurang tepatnya pemberian sanksi, belum dimanfaatkannya pergeseran beban pembuktian, keterbatasan akses informasi, sempitnya cakupan pelapor dan jenis laporannya, serta kurang jelasnya tugas dan kewenangan dari para pelaksana Undang-Undang ini (UU No. 8 Tahun 2010).

Untuk memenuhi kepentingan nasional dan menyesuaikan standar internasional, perlu disusun Undang-Undang tentang Pencegahan dan Pemberantasan Tindak Pidana Pencucian Uang sebagai pengganti Undang-Undang Nomor 15 Tahun 2002 tentang Tindak Pidana Pencucian Uang sebagaimana telah diubah dengan Undang-Undang Nomor 25 Tahun 2003 tentang Perubahan atas Undang-Undang Nomor 15 Tahun 2002 tentang Tindak Pidana Pencucian Uang (UU No. 8 Tahun 2010).

Materi muatan yang terdapat dalam Undang-Undang ini, antara lain (UU No. 8 Tahun 2010):

1. redefinisi pengertian hal yang terkait dengan tindak pidana Pencucian Uang;

2. penyempurnaan kriminalisasi tindak pidana Pencucian Uang;

3. pengaturan mengenai penjatuhan sanksi pidana dan sanksi administratif;

4. pengukuhan penerapan prinsip mengenali Pengguna Jasa;

5. perluasan Pihak Pelapor;

6. penetapan mengenai jenis pelaporan oleh penyedia barang dan/atau jasa lainnya;

7. penataan mengenai Pengawasan Kepatuhan;

8. pemberian kewenangan kepada Pihak Pelapor untuk menunda Transaksi;

9. perluasan kewenangan Direktorat Jenderal Bea dan Cukai terhadap pembawaan uang tunai dan instrumen pembayaran lain ke dalam atau ke luar daerah pabean;

10. pemberian kewenangan kepada penyidik tindak pidana asal untuk menyidik dugaan tindak pidana Pencucian Uang; 
11. perluasan instansi yang berhak menerima hasil analisis atau pemeriksaan PPATK;

12. penataan kembali kelembagaan PPATK;

13. penambahan kewenangan PPATK, termasuk kewenangan untuk menghentikan sementara Transaksi;

14. penataan kembali hukum acara pemeriksaan tindak pidana Pencucian Uang; dan

15. pengaturan mengenai penyitaan Harta Kekayaan yang berasal dari tindak pidana.

Pengertian pencucian uang dalam UU No. 25 Tahun 2003 adalah perbuatan menempatkan, mentransfer, membayarkan, membelanjakan, menghibahkan, menyumbangkan, menitipkan, membawa ke luar negeri, menukarkan, atau perbuatan lainnya atas harta Kekayaan yang diketahui atau patut diduga merupakan hasil tindak pidana dengan maksud untuk menyembunyikan, atau menyamarkan asal usul harta kekayaan sehingga seolah-olah menjadi harta kekayaan yang sah (Pasal 1 angka 1 UndangUndang No. 25 tahun 2003 tentang Perubahan atas Undang-Undang No. 15 tahun 2002 tentang Tindak Pidana Pencucian Uang).

Sedangkan dalam UU No. 8 Tahun 2010 tentang Pencegahan dan Pemberantasan Tindak Pidana Pencucian Uang, pengertian pencucian uang mengalami perluasan menjadi segala perbuatan yang memenuhi unsur-unsur tindak pidana sesuai dengan ketentuan dalam Undang-Undang ini.

\subsubsection{Tindak Pidana Pencucian Uang di sektor kehutanan}

Menurut Pasal 2 ayat (1) dalam UU Pencegahan dan Pemberantasan Tindak Pidana Pencucian Uang, hasil tindak pidana adalah harta kekayaan yang diperoleh dari tindak pidana:
a. korupsi;
b. penyuapan;
c. narkotika;
d. psikotropika;
e. penyelundupan tenaga kerja;
f. penyelundupan migran;
g. di bidang perbankan;
h. di bidang pasar modal;
i. di bidang perasuransian;
j. kepabeanan;
k. cukai;
1. perdagangan orang;
m. perdagangan senjata gelap;
n. terorisme;
o. penculikan;
p. pencurian;
q. penggelapan; 
r. penipuan;

s. pemalsuan uang;

t. perjudian;

u. prostitusi;

v. di bidang perpajakan;

w. di bidang kehutanan;

x. di bidang lingkungan hidup;

y. di bidang kelautan dan perikanan; atau tindak pidana lain yang diancam dengan pidana penjara 4 (empat) tahun atau lebih, yang dilakukan di wilayah Negara Kesatuan Republik Indonesia atau di luar wilayah Negara Kesatuan Republik Indonesia dan tindak pidana tersebut juga merupakan tindak pidana menurut hukum Indonesia.

z. Tindak pidana yang dimaksud dalam Pasal 2 diatas, merupakan tindak pidana asal yaitu tindak pidana yang memicu (sumber) terjadinya tindak pidana pencucian uang (PPATK 2010).

Berdasarkan UU Pencegahan dan Pemberantasan Tindak Pidana Pencucian Uang, perbuatan pencucian uang dapat dikelompokkan menjadi aktif dan pasif (Husein 2010). Tindak pidana pencucian uang yang aktif melibatkan orang yang sengaja melakukan pencucian uang sebagaimana diatur dalam Pasal 3 dan Pasal 4 yaitu:

\section{Pasal 3}

Setiap Orang yang menempatkan, mentransfer, mengalihkan, membelanjakan, membayarkan, menghibahkan, menitipkan, membawa ke luar negeri, mengubah bentuk, menukarkan dengan mata uang atau surat berharga atau perbuatan lain atas Harta Kekayaan yang diketahuinya atau patut diduganya merupakan hasil tindak pidana sebagaimana dimaksud dalam Pasal 2 ayat (1) dengan tujuan menyembunyikan atau menyamarkan asal usul Harta Kekayaan dipidana karena tindak pidana Pencucian Uang dengan pidana penjara paling lama 20 (dua puluh) tahun dan denda paling banyak Rp10.000.000.000 (sepuluh miliar rupiah).

\section{Pasal 4}

Setiap Orang yang menyembunyikan atau menyamarkan asal usul, sumber, lokasi, peruntukan, pengalihan hak-hak, atau kepemilikan yang sebenarnya atas Harta Kekayaan yang diketahuinya atau patut diduganya merupakan hasil tindak pidana sebagaimana dimaksud dalam Pasal 2 ayat (1) dipidana karena tindak pidana Pencucian Uang dengan pidana penjara paling lama 20 (dua puluh) tahun dan denda paling banyak Rp 5.000.000.000 (lima miliar rupiah).

Berdasarkan Pasal 1 angka 13 UU Pencegahan dan Pemberantasan Tindak Pidana Pencucian Uang, yang dimaksud dengan harta kekayaan adalah semua benda bergerak maupun benda tidak bergerak, baik berwujud maupun tidak berwujud, yang diperoleh baik secara langsung maupun tidak langsung. 
Unsur obyektif pada Pasal 3 di atas adalah menempatkan, mentransfer, mengalihkan, membelanjakan, membayarkan, menghibahkan, menitipkan, membawa ke luar negeri, mengubah bentuk, menukarkan dengan mata uang atau surat berharga atau perbuatan lain atas Harta Kekayaan yang diketahuinya atau patut diduganya merupakan hasil tindak pidana. Sedangkan unsur subyektifnya adalah sengaja, mengetahui, atau patut diduga bahwa harta kekayaan berasal dari hasil kejahatan, dengan maksud menyembunyikan atau menyamarkan asal-usul harta kekayaan tersebut.

Berdasarkan uraian di atas, maka unsur-unsur pokok dalam proses pencucian uang dapat disajikan pada Gambar 3.

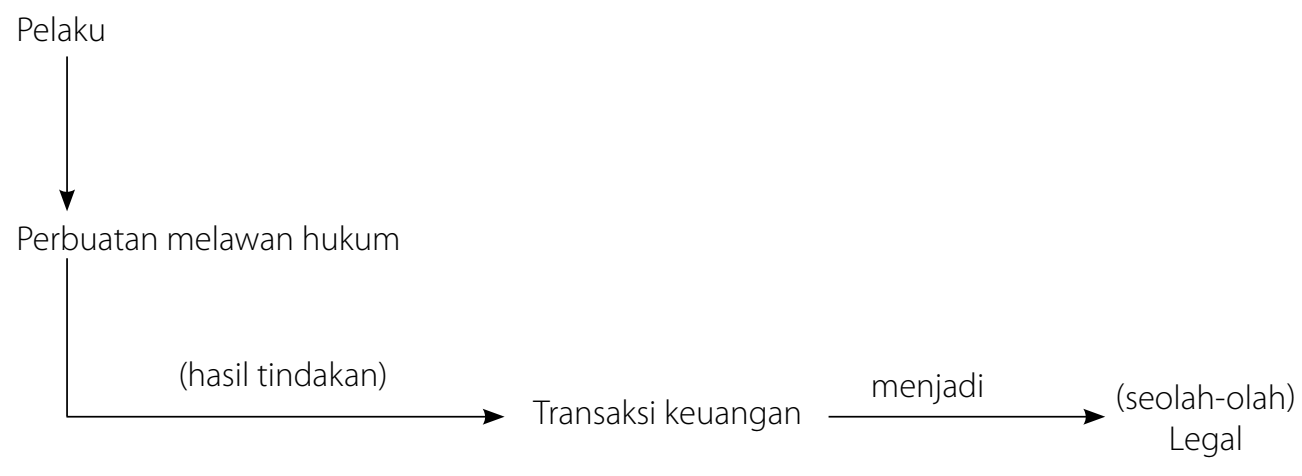

\section{Gambar 3. Unsur-Unsur Pokok Pencucian Uang}

Sumber: BPK (2008)

Selanjutnya, tindak pidana yang bersifat pasif yaitu yang dilakukan oleh orang yang menerima atau menguasai hasil pencucian uang. Berdasarkan Pasal 5 pelaku tindak pidana pasif adalah setiap orang yang menerima atau menguasai harta kekayaan yang diketahuinya atau patut diduganya merupakan hasil tindak pidana melalui:
a. Penempatan;
b. Pentransferan;
c. Pembayaran;
d. Hibah;
e. Sumbangan;
f. Penitipan;
g. Penukaran atau
h. Menggunakan harta kekayaan,

Unsur obyektif dalam Pasal 5 di atas adalah perbuatan penempatan, pentransferan, pembayaran, hibah, sumbangan, penitipan, penukaran atau menggunakan harta kekayaan yang diketahuinya atau patut diduganya merupakan hasil tindak pidana. Sedangkan unsur subyektifnya adalah mengetahui, atau patut diduga, bahwa harta kekayaan yang didapat merupakan hasil tindak pidana. 
Untuk mendapatkan cakupan yang lebih luas, maka dalam Pasal 6 diatur mengenai tindak pidana pencucian uang yang dilakukan oleh korporasi. Serta Pasal 10 yang mengatur bahwa setiap orang yang berada di dalam atau diluar wilayah Negara Republik Indonesia yang turit serta melakukan percobaan, pembantuan atau permufakatan jahat untuk terjadinya tindak pidana pencucian uang, dapat dipidana.

Pasal-pasal di atas dapat digunakan untuk menangani kejahatan bidang kehutanan yang terkait dengan tindak pidana pencucian uang, seperti ditunjukkan dalam modus operandi (Husein 2007) berikut:

a. Untuk memperlancar kegiatan bisnisnya, pelaku pembalakan liar diduga secara rutin menyetorkan uang suap dalam jumlah besar ke rekening oknum pejabat dan oknum aparat terkait.

b. Selain pengusaha lokal, beberapa pelaku pembalakan liar berasal dari Malaysia, yang dalam melakukan kegiatannya menggunakan identitas beberapa WNI untuk membuka rekening di bank dan menjadi pengurus perusahaan. Selanjutnya kontrol atas rekening dan perusahaan dimaksud diduga dilakukan oleh orang asing tersebut.

Tabel 7. Contoh Perkara Tindak Pidana Pencucian Uang dalam Kejahatan di Bidang Kehutanan

\begin{tabular}{ll}
\hline Kejahatan & Pasal dalam UU No. 8 Tahun $\mathbf{2 0 1 0}$ \\
\hline $\begin{array}{l}\text { Menyetor uang hasil transaksi pembalakan liar ke } \\
\text { rekening bank }\end{array}$ & Pasal 3 UU TPPU \\
\hline $\begin{array}{l}\text { Membeli polis asuransi dengan menggunakan } \\
\text { uang hasil pembalakan liar }\end{array}$ & Pasal 3 UU TPPU \\
\hline $\begin{array}{l}\text { Mentransfer uang hasil pembalakan liar yang } \\
\text { telah ditempatkan di PJK ke pedagang valuta }\end{array}$ & Pasal 3 UU TPPU \\
$\begin{array}{l}\text { asing, kemudian ditukarkan ke dalam mata uang } \\
\text { asing atau sebaliknya. }\end{array}$ & \\
\hline $\begin{array}{l}\text { Memindahbukukan ke beberapa rekening di } \\
\text { bank yang sama, baik atas nama sendiri atau }\end{array}$ & \\
nama orang lain uang hasil pembalakan liar 3 ayat (1) huruf b UU TPPU & \\
\hline $\begin{array}{l}\text { Menginvestasikan uang hasil pembalakan liar ke } \\
\text { dalam bisnis kelapa sawit (contoh kasus antara }\end{array}$ & Pasal 3 UU TPPU \\
$\begin{array}{l}\text { lain seorang pengusaha kehutanan di Sumatera } \\
\text { Utara menginvestasikan dana yang diduga }\end{array}$ \\
$\begin{array}{l}\text { berasal dari kejahatan kehutanan ke bisnis } \\
\text { kelapa sawit) }\end{array}$ \\
$\begin{array}{l}\text { Menginvestasikan uang hasil pembalakan liar ke } \\
\text { dalam bisnis resort atau hotel. }\end{array}$ \\
\hline
\end{tabular}


Modus operandi lain yang digunakan pada tindak pidana pencucian uang dalam kejahatan di bidang kehutanan ditunjukkan dalam Gambar 4.

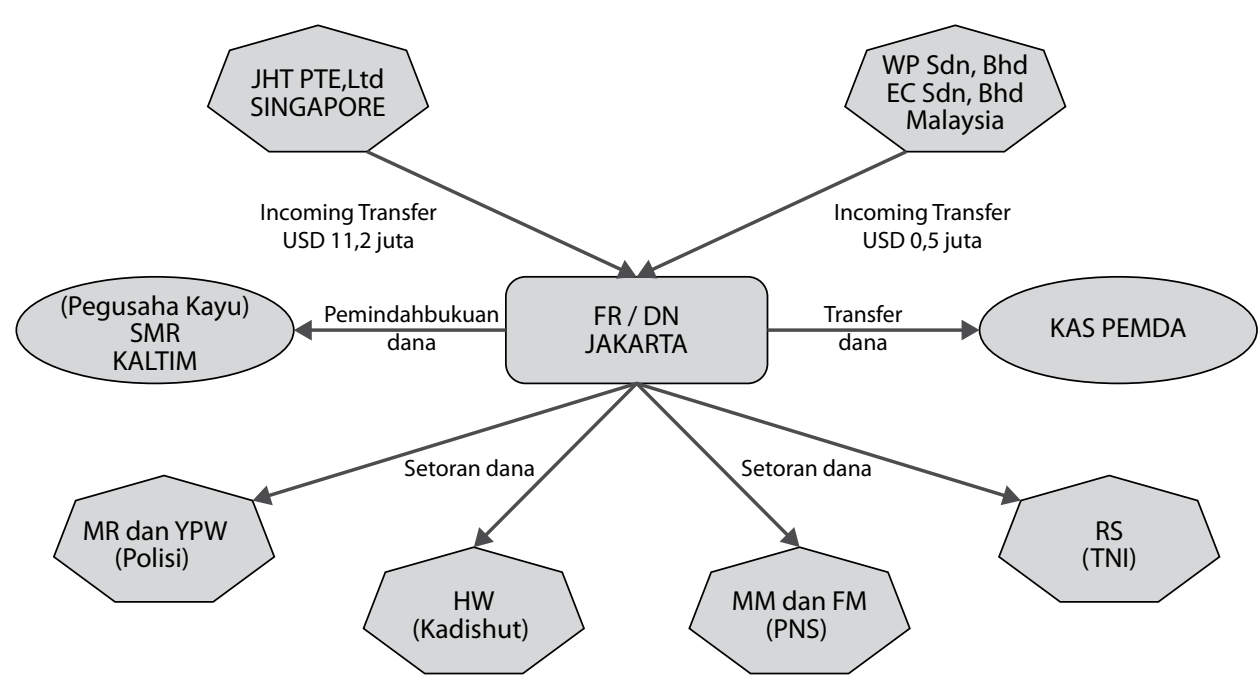

\section{Gambar 4. Ilustrasi Pendanaan Pembalakan Liar}

Selama periode 2001-2004 DN dan WST (kuasa FR) diduga mengekspor kayu olahan ke Malaysia dan Singapura melalui PT SM Jakarta. Hal ini diketahui dari transfer USD 11,2 juta dari JHT PTE Ltd (Singapura) dan USD 0,5 juta dari WP Sdn Bhd, EC Sdn Bhd, Ti Co, dan ST Co (Malaysia). Atas transfer tersebut, sebagian besar dananya ditransfer oleh DN dan WST ke SMR (pengusaha kayu) di Samarinda dan pejabat Pemda Papua serta Kas Pemda Papua.

Di samping itu, DN dan WST juga menarik dan langsung menyetorkan dana kepada oknum Polisi (MR dan YPW), oknum PNS (MM dan FM), oknum TNI (RS) dan Oknum Pejabat Dinas Kehutanan (HW) sebesar USD128,4 ribu (Rp1,146 miliar). Oknum MR yang pada waktu menjabat sebagai Kepala Unit Reserse tidak melakukan penindakan terhadap perusahaan milik FR, padahal perusahaan milik FR diduga melakukan pembalakan liar (PPATK 2007).

Kasus lain menggambarkan adanya aliran uang dari pembalakan liar bisa dilihat pada kasus Usaha Pemanfaatan Hasil Hutan Kayu (UPHHK) di Sumatera Utara. Berdasarkan Keputusan Menteri Kehutanan dan Perkebunan RI Nomor : 805/KptsIV/1999, tanggal 30 September 1999, perusahaan pemegang izin mendapatkan fasilitas dari pemerintah yaitu Usaha Pemanfaatan Hasil Hutan Kayu (UPHHK) seluas kurang lebih 58 ribu Ha yang terletak di Sumatera Utara. Izin ini diberikan jangka waktu 35 Tahun, yaitu mulai tahun 1994 hingga tahun 2029. Profil transaksi perusahaan pemegang izin dalam melakukan kegiatannya secara ringkas dapat dijelaskan pada Gambar 5 . 


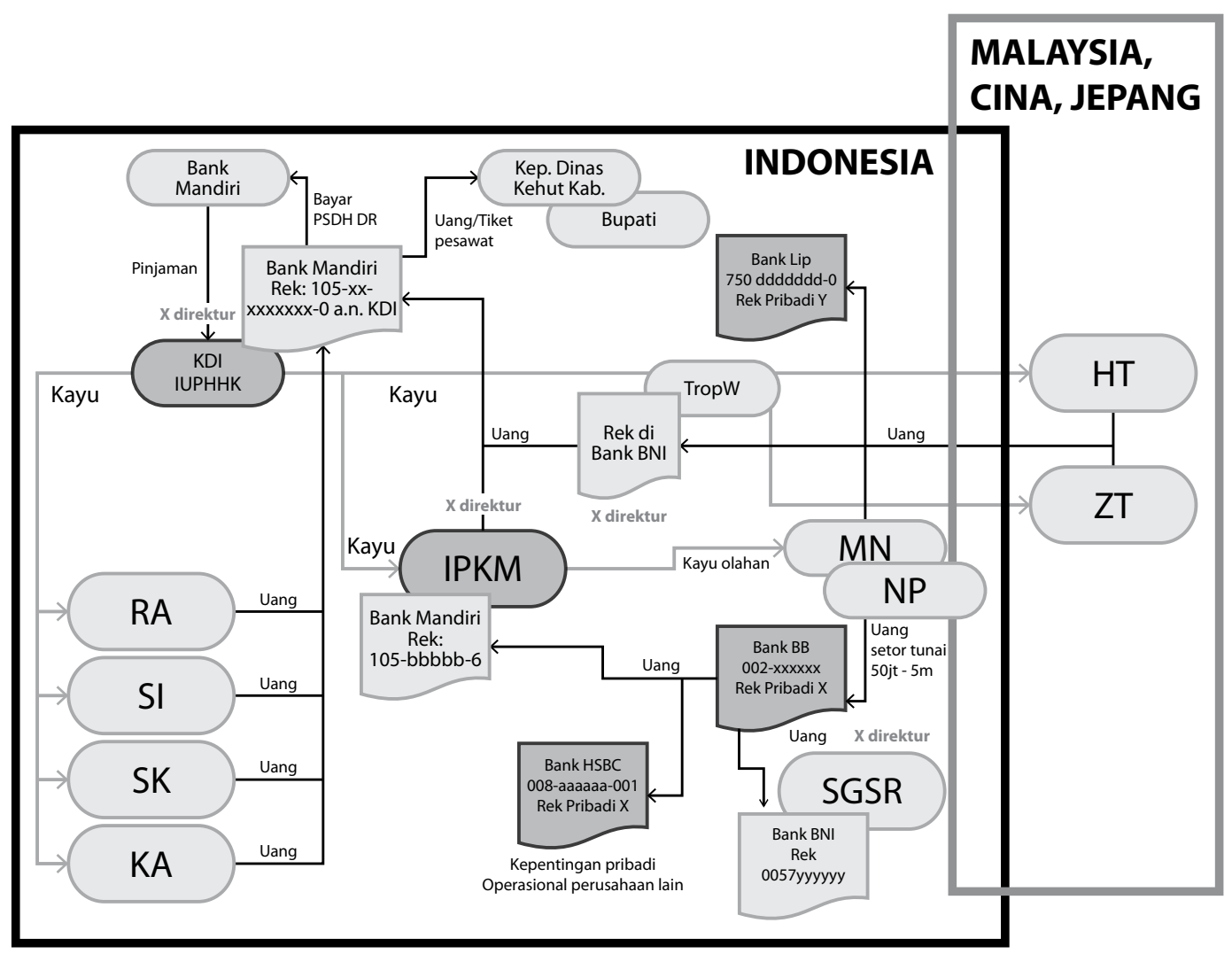

\section{Gambar 5. Contoh Kasus Ilustrasi Aliran Uang dari Pembalakan Liar}

Sumber: Eriantono dan Setiono (Tidak diterbitkan)

Profil kasus pemegang izin adalah sebagai berikut:

- KDI melakukan penebangan berdasarkan LHC fiktif. Kabag Perencanaan KDI dalam membuat rekapitulasi LHC periode tahun 2000 hingga tahun 2002 atas perintah Direktur Produksi/Perencanaan bukan berdasarkan data lapangan.

- Selanjutnya Kabag Perencanaan mengirimkan rekapitulasi tersebut kepada Manager Cabang dan terus menyampaikannya kepada Manager Camp untuk digunakan sebagai dasar dalam pembuatan LHC oleh petugas Cruiser. Petugas cruiser kemudian membuat dan menanda tangani LHC tanpa melakukan kegiatan Timber Cruising.

- Berikutnya LHC tersebut dikirimkan ke Manager Perwakilan untuk bahan usulan RKT setiap tahun.

- KDI melakukan penebangan tanpa melaksanakan kegiatan sistim Silvikultur Tebang Pilih Tanam Indonesia (TPTI).

- Buku RKT IUPHHK KDI yang dibuat oleh Direktur Produksi/Perencanaan KDI dan ditanda tangani oleh Direktur Utama KDI untuk disahkan oleh Kepala Dinas Kehutanan Propinsi Sumatera Utara dan Bupati yang mengalokasikan nilai anggaran tiap-tiap kegiatan TPTI pada masing-masing URKT, tidak dilaksankan oleh KDI. 
- Dengan tidak melakukan TPTI mengakibatkan penebangan pohon kayu hasil hutan dari periode tahun 2000 hingga tahun 2005 tidak sesuai dengan ketentuan yang berlaku, antara lain lokasi penebangan berada diluar Blok Tebangan /Petak Tebangan Rencana Karya Tahunan dan menimbulkan kerusakan hutan.

- Menurut ahli dari Kementerian Lingkungan Hidup menimbulkan kerugian sebesar kurang lebih Rp.200 trilyun meliputi kerusakan ekologi sebesar Rp 95 trilyun, kerusakan ekonomi sebesar Rp.47 trilyun, dan pemulihan ekologi sebesar Rp 58 trilyun.

- KDI melakukan penebangan di luar RKT. Dalam dokumen Rencana Karya Tahunan (RKT) telah ditetapkan mengenai rencana kegiatan penebangan di blok tebangan dan anggaran yang berkaitan dengan penebangan, namun pemegang IUPHHK,KDI, tidak dilaksanakan penebangan di dalam RKT/Blok Tebangan (penebangan pohon secara Illegal).

- Pemegang izin pada periode tahun 2000 melakukan penebangan pohon di luar RKT, yaitu pada titik koordinat $00^{0} \mathrm{xx}$ xx,4" LU dan yy yy' yy,4” BT. Penebangan menggunakan alat mesin Chain Saw dan hasil penebangan sekitar 12 ribu batang atau volume sekitar 30 ribu $\mathrm{m}^{3}$, dengan jenis Meranti, Kapur, Keruing, Damar, Resak, Jelutung dan Kelompok Rimba Campuran.

- Pada tahun 2005 pada titik koordinat $00^{\circ}$ zz' zz,4” LU dan ww ${ }^{0}$ ww' ww,2” BT. Hasil penebangan sekitar 12 ribu batang atau volume sekitar 28 ribu $\mathrm{m}^{3}$, dengan jenis Meranti, Kapur, Keruing, Damar, Resak, Jelutung dan Kelompok Rimba Campuran.

- KDI melakukan pengangkutan kayu dengan Surat Keterangan Sahnya Hasil Hutan yang tidak sah.

- Pemegang izin melakukan pengangkutan kayu bulat hasil hutan dengan menggunakan alat angkut ponton yang ditarik dengan kapal tarik dilengkapi dengan Dokumen Surat Keterangan Sahnya Hasil Hutan (SKSHH) yang tidak sah karena dokumen SKSHH disalin dari isi LHC fiktif.

Dokumen SKSHH fiktif karena tidak sama dengan keadaan fisik kayu bulat, baik jenis, jumlah, maupun volumenya. Karena adanya imbalan yang diterimanya, petugas P2SKSHH dalam menerbitkan SKSHH, tidak melakukan pemeriksaan fisik kayu bulat di TPK dan langsung menerbitkan SKSHH sesuai dengan permintaan pemohon IUPHHK KDI, demikian pula Kepala Sub Dinas Bina Produksi pada Dinas Kehutanan Kabupaten menandatangani dan menyetujui SKSHH masih dalam keadaan blanko kosong namun blanko dokumen SKSHH tersebut telah ditandatangani oleh P2SKSHH.

- KDI melakukan pembayaran PSDH dan DR berdasarkan LHP Fiktif. Pemegang izin sejak tahun 2000 hingga tahun 2005 melakukan pembayaran Provisi Sumber Daya Hutan (PSDH) dan Dana Reboisasi (DR), bukan atas kayu bulat yang ditebangnya melainkan berdasarkan LHP fiktif. Dana pembayaran PSDH dikirimkan ke Rekening Bendaharawan Penerima Setoran Murni PSDH di Bank Mandiri Cabang Jakarta Gedung Pusat Kehutanan dengan No. Rekening: 1020004204001, sedangkan dana untuk pembayaran DR dikirimkan ke Rekening 
Bendaharawan Penerima Setoran Murni DR di Bank Mandiri Cabang Jakarta Gedung Pusat Kehutanan dengan No. Rekening: 1050001480700.

- KDI melakukan pemindahan dana antar bank dari hasil penjualan kayu bulat. Kayu Bulat hasil produksi IUPHHK KDI sebagian besar dipasarkan/dijual ke Industri Primer Hasil Hutan Kayu (IPHHK) M yaitu induk perusahaan KDI. Selain itu kayu bulat dijual ke Malaysia, Cina, Jepang dan India. Sedangkan di dalam negeri dijual ke RA, SI, SK, KA dan TR. Penjualan kayu bulat baik ke luar negeri dan ke dalam negeri dengan menggunakan Kontrak Jual Beli Kayu Bulat. Kontrak ditandatangani oleh X, Direktur Keuangan KDI dengan calon pembeli kayu bulat.

Proses pembayaran penjualan keluar negeri dengan menggunakan Latter Of Credit (LC), kemudian LC tersebut dicairkan di Bank Mandiri dan dana langsung di transfer ke rekening KDI no. 105-xx-xxxxxxx-0 a.n KDI. Sedangkan penjualan di dalam negeri dilakukan dengan cara tunai atau kredit. Uang hasil penjualan kayu bulat IUPHHK KDI kepada IPK M ditransfer oleh IPK M ke rekening KDI di Bank Mandiri setelah melalui transfer antar rekening pribadi X di bank BB dan Bank HSBC.

Mutasi rekening No. 105-xx-xxxxxxx-0 a.n KDI secara rinci, nampak pada Gambar 6.

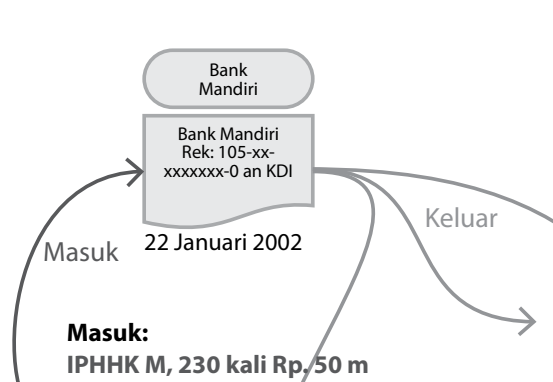

TropW, 6 kali sebesar Rp. $1 \mathrm{~m}$

PLP, 1 kali sebesar Rp. 200 juta

Y, 4 kali sebesar Rp. 1,7 m

KDI Jkt, 2 kali sebesar Rp. 3,7 juta

ADL, 2 kali sebesar Rp. 450 juta

KPPN II, 1 kali sebesar Rp. 316 juta

Keluar:

STaniM, 83 kali sebesar Rp. $5 \mathrm{~m}$

DH, 154 kali sebesar Rp. $8 \mathrm{~m}$

AH, 54 kali sebesar Rp. $2 \mathrm{~m}$

$\mathrm{Y}, 30$ kali sebesar Rp. $3 \mathrm{~m}$

Bend PSDH, 23 kali sebesar Rp. 2 m

CBaru, 27 kali sebesar Rp. 1,3 m

HWya, 8 kali sebesar Rp. 400 juta

Japiz, 76 kali sebesar Rp. 1,2 m

KStar, 45 kali sebesar Rp. 282 juta

Bank Lip rek 750.gggggggggg.1

KKN Persepsi, 74 kali sebesar Rp. 2,4 m

\section{Keluar:}

LAn, 17 kali sebesar Rp. 472 juta

PBB, 19 kali sebesar Rp. 999 juta

C'diri, 10 kali sebesar Rp. 580 juta

MLL Lika Lestari, 8 kali sebesar Rp. 46 juta

KDI Jkt, 25 kali sebesar Rp. 188 juta

IPHHK M, 9 kali sebesar Rp. 2,8 m

S.S, 5 kali sebesar Rp. 4,5 m

SA, 9 kali sebesar Rp. 600 juta

TZ, 5 kali sebesar Rp. 250 juta

TA, 3 kali sebesar Rp. 150 juta

Sd, 1 kali sebesar Rp. 300 juta

RSk, 2 kali sebesar Rp. 200 juta

TamaW, 1 kali sebesar Rp. 22 juta

Hwas, 1 kali sebesar Rp. 1 juta

DTAM, 2 kali sebesar Rp. 8 juta

Pertamina, 1 kali sebesar Rp. 495 juta

Om, 1 kali sebesar Rp. 15 juta

Nor, 1 kali sebesar Rp. 43 juta

Min, 1 kali sebesar Rp. 50juta

Mei, 2 kali sebesar Rp. 91 juta

Msus, 1 kali sebesar Rp. 17 juta

LSK, 2 kali sebesar Rp. 100 juta

LL, 6 kali sebesar Rp. 99 juta

LS, 1 kali sebesar Rp. 95 juta
22 Januari 2002,

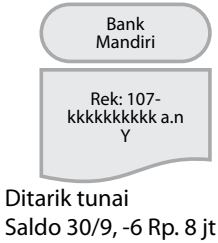

22 Januari 2002,

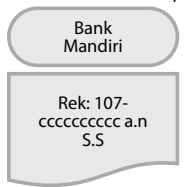

Masuk Rp. 3,5 m

Ditarik tunai

Saldo 30/9, 06 Rp. 1,8 jt

22 Januari 2002,

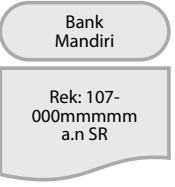

Masuk Rp. 180 juta

Ditarik tunai

Saldo 30/06 Rp. 170 jt

\section{Gambar 6. Arus Mutasi Rekening}

Sumber: Eriantono dan Setiono (Tidak diterbitkan) 
Terkait dengan penggunaan dana dari rekening: 105-xx-xxxxxxx-0 a.n KDI di Bank Mandiri, direktur keuangan KDI tidak mengetahui apa itu sesuai dengan anggaran dasar perusahaan KDI, namun dalam setiap pencairan uang dari rekening tersebut harus ada tanda tangan direktur keuangan KDI pada Giro atau Cek yang akan dicairkan.

- IPHHK M melakukan pemindahan dana antar bank melalui rekening pribadi dari hasil penjualan kayu olahan. Kayu bulat yang dibeli IPHHK M dari IUPHHK KDI kemudian diolah menjadi kayu olahan dan dijual kepada MN. Hasil penjualan kayu olahan kepada MN tersebut ditampung pada rekening pribadi nomor 002.xxxxxx a.n. X pada bank BB dan nomor 750ddddddd-0 a.n Y (saudara kandung X) pada Bank Lip. Dari mutasi rekening menunjukkan adanya aliran dana masuk dari MN karena transaksi penjualan kayu olahan IPHHK M kepada MN. Dari rekening yang sama menujukkan adanya aliran dana keluar ke rekening pribadi milik X pada Bank HSBC nomor 08-aaaaaa-001.

- Setelah X menerima uang hasil penjualan kayu pada rekening pribadinya di Bank BB No. 002.xxxxxx, lalu dana tersebut ditransfer ke rekening SGSR No. Rek: 0057yyyyyy Bank BNI, atas nama X dan ke rekening No. Rek: 105.bbbbb-6, atas nama IPHHK M.

- Hasil penjualan kayu bulat atas nama IUPHHK KDI ke IPHHK M yang diolah menjadi Plywood kemudian dijual kepada MN dan NP yang ditampung nomor 002.xxxxxx a.n. X pada bank BB tersebut telah digunakan untuk kepentingan pribadi yang tidak ada hubungannya dengan kegiatan KDI.

- KDI mendapatkan fasilitas pinjaman dari Bank Mandiri (sebelumnya BDN). Fasilitas kredit tersebut digunakan sebagai modal kerja KDI. Jaminan atas fasilitas kredit adalah alat-alat berat milik KDI yang diagunkan ke Bank Mandiri.

- KDI memberikan hadiah/ticket pesawat kepada Kep. Dinas Kehutanan Kabupaten dan Bupati. X, direktur Keuangan KDI dan Direktur M memberikan hadiah berupa ticket pesawat kepada Kep. Dinas Kehutanan Kabupaten dan Bupati dalam proses pengusahaan hasil hutan kayu pada IUPHHK KDI dan IPHHK M.

\subsection{Pendekatan ILEA Melalui UU Pemberantasan Tindak Pidana Korupsi dan UU Pencegahan dan Pemberantasan Tindak Pidana Pencucian Uang}

Kasus di atas adalah satu dari berbagai kasus pencucian uang di sektor kehutanan. Dalam beberapa kasus, tindak pidana pencucian uang dalam sektor kehutanan dapat terjadi sejak proses perijinan dikeluarkan hingga penjualan kayu hasil penebangan liar. Apabila kita menggunakan pendekatan tindak pidana korupsi dan tindak pidana pencucian uang, maka tindakan korupsi dan pencucian uang di sektor kehutanan dapat terjadi seperti yang dijabarkan dalam Tabel 8 . 


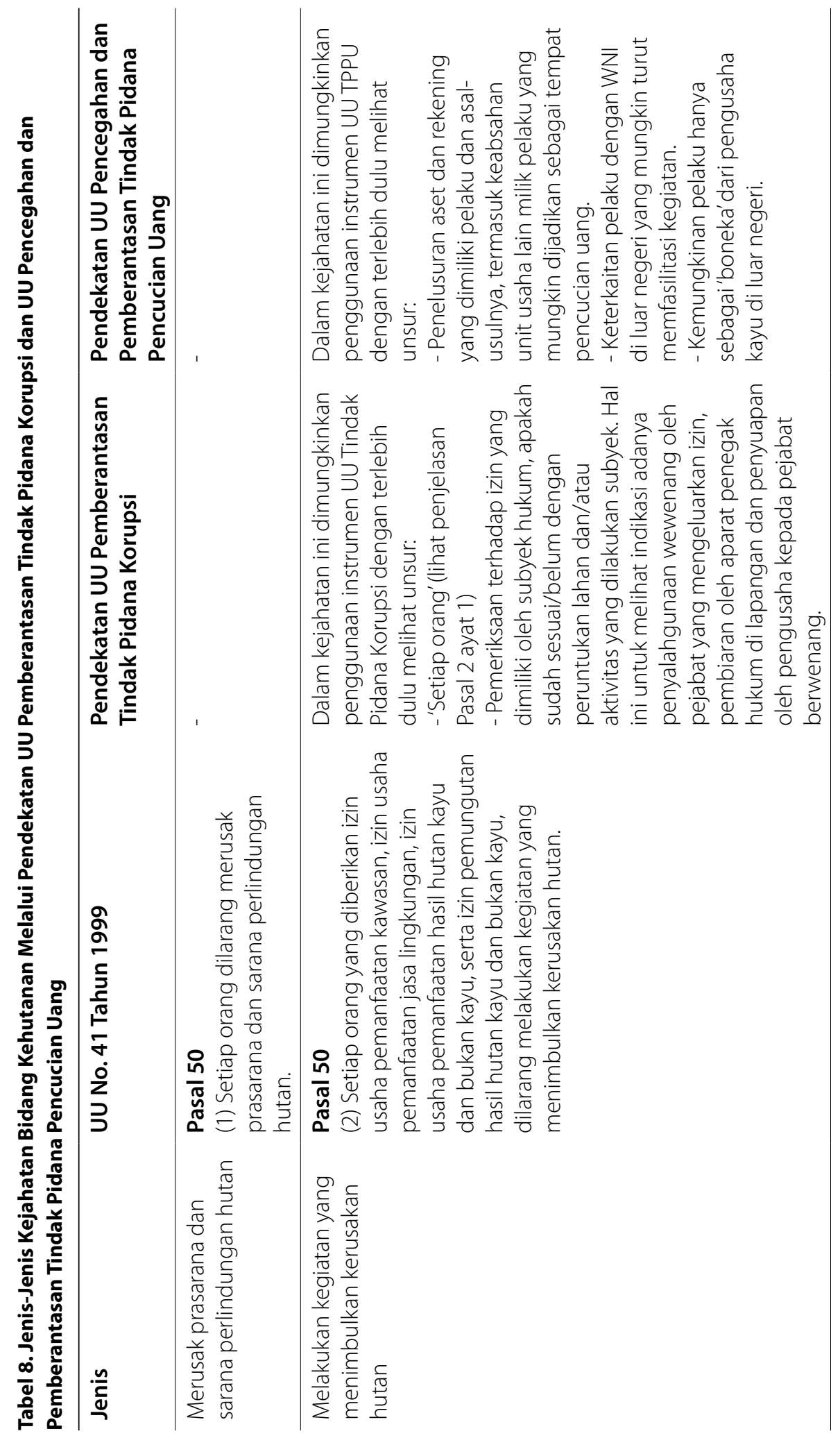




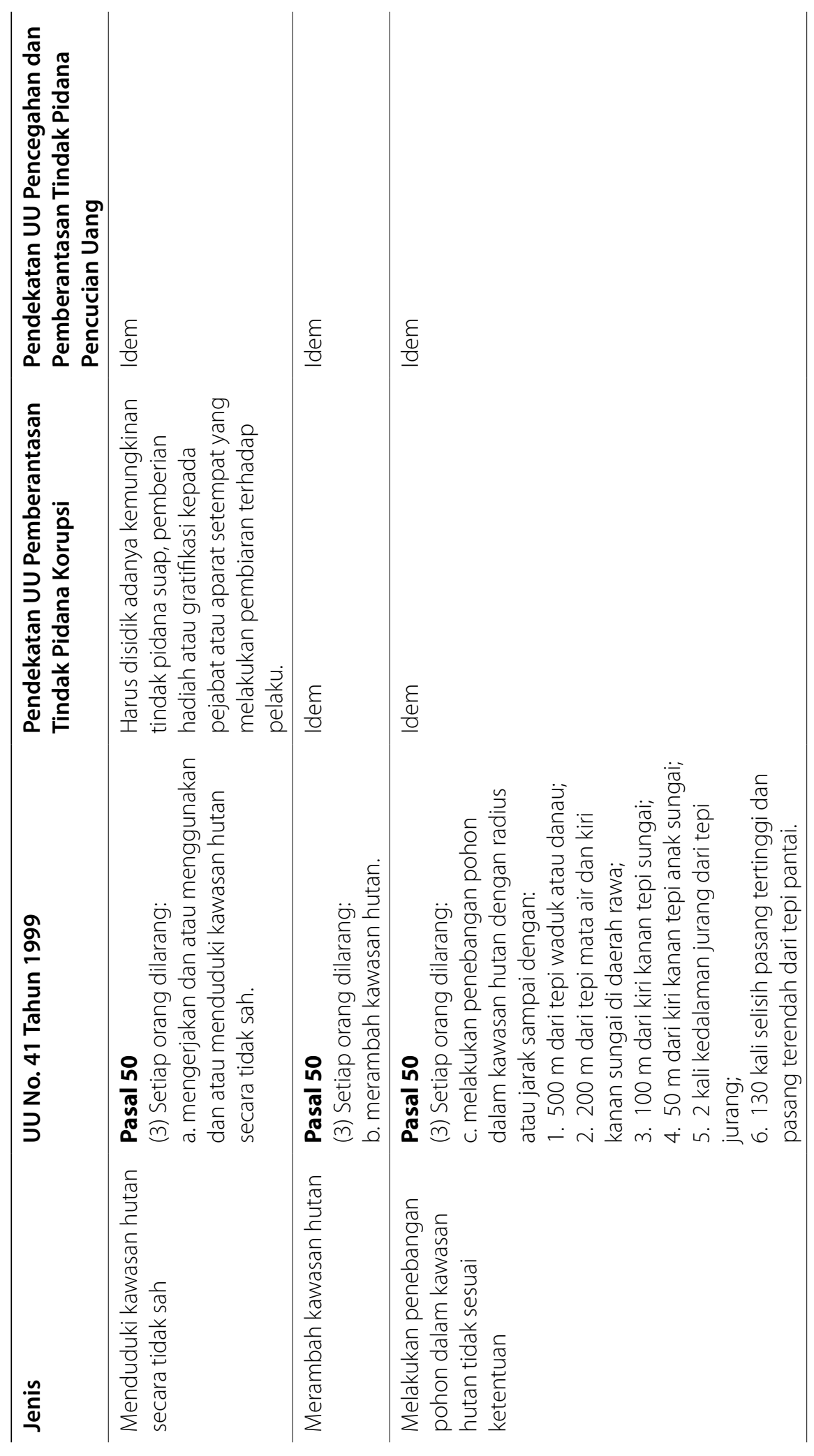




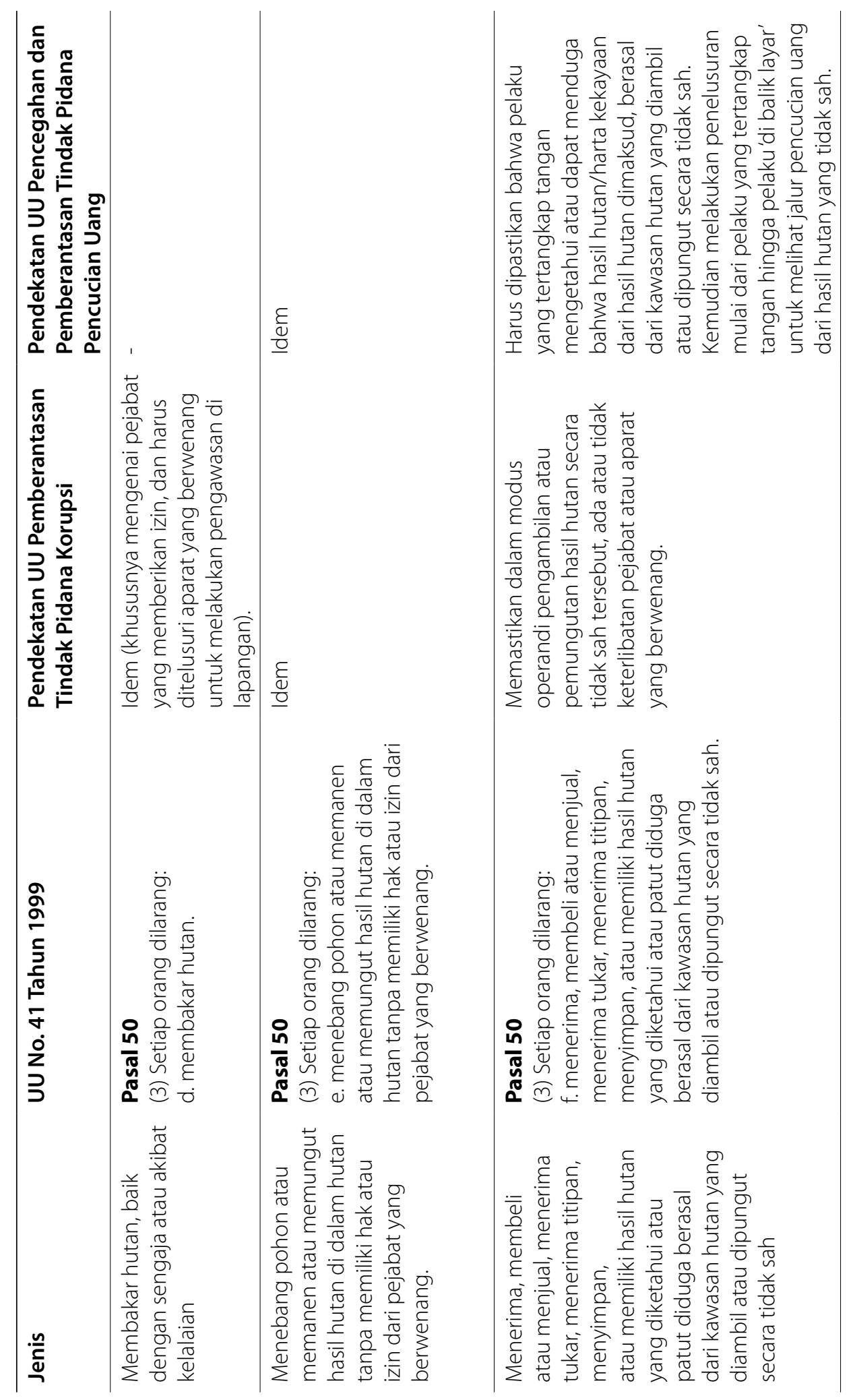




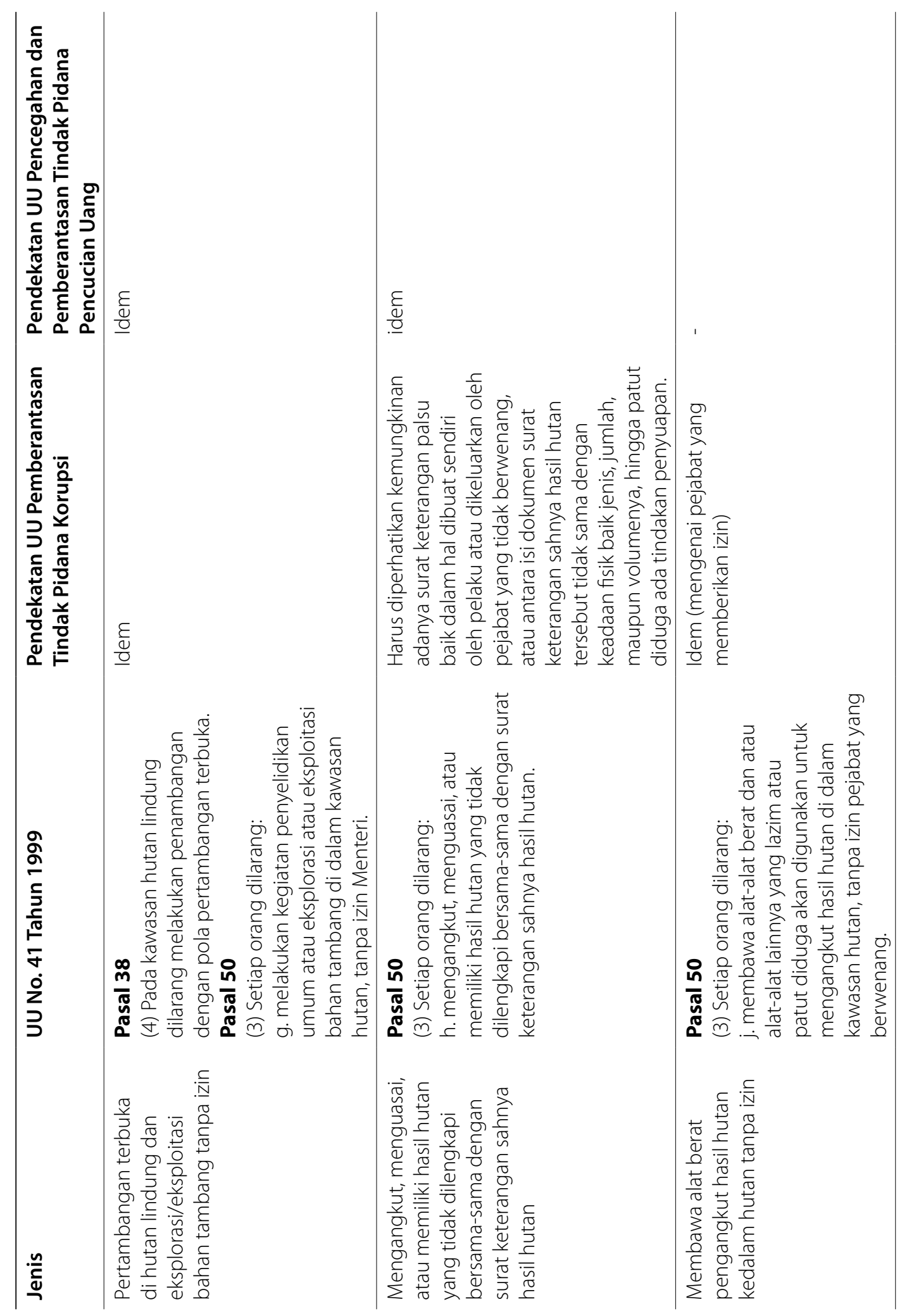




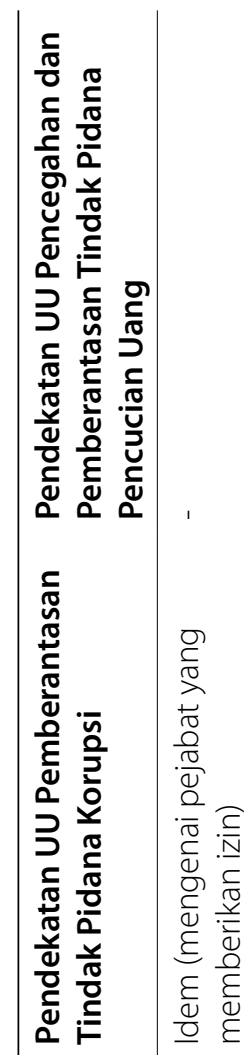

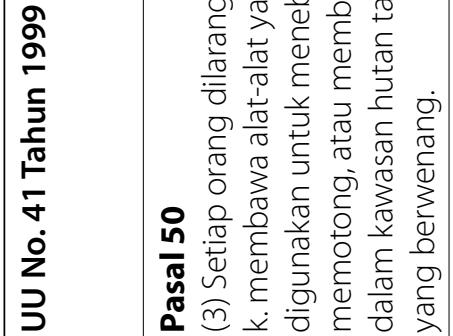

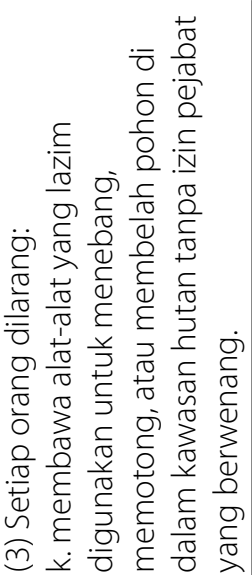

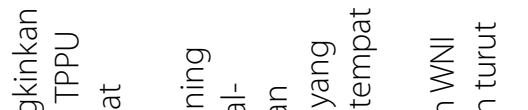

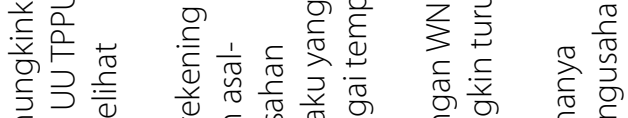

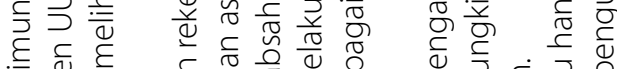

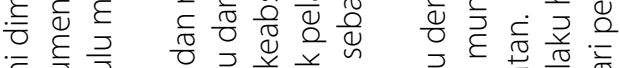

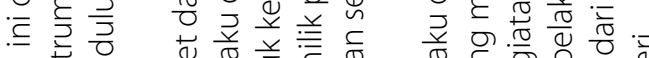

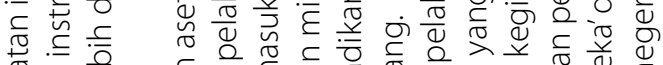

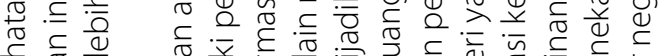

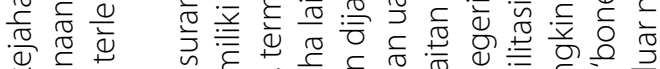

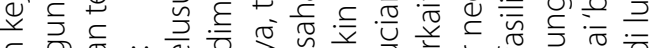

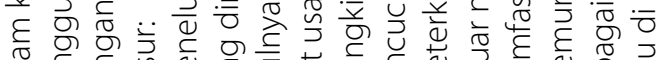

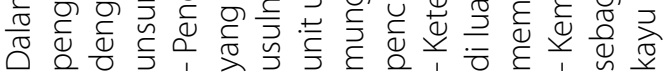

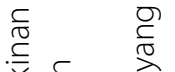

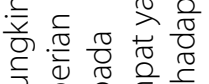

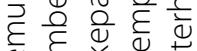

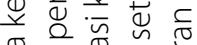

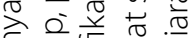

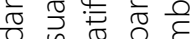

ช ज

咅

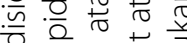

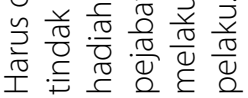

$+\frac{\pi}{\frac{0}{5}} \frac{0}{\circ}$

요료

Oำ $\frac{2}{2} \frac{\sqrt{0}}{\frac{\pi}{0}}$

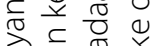

응 $\frac{0}{0} \frac{0}{2}$

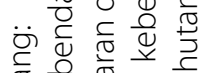

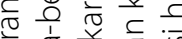

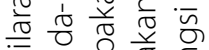

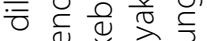

O)

व

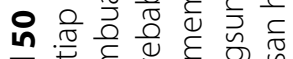

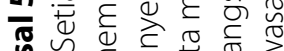

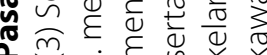

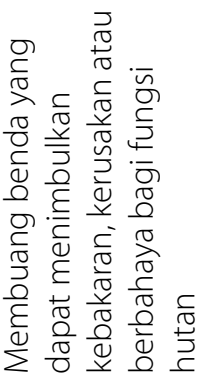


Dari jenis-jenis kejahatan kehutanan sebagaimana disebutkan di atas, maka dapat digambar sebuah alur proses kejahatan kehutanan yang juga melibatkan tindak pidana lainnya, seperti tindak pidana korupsi dan pencucian uang sebagaimana terlihat dalam Gambar 7.

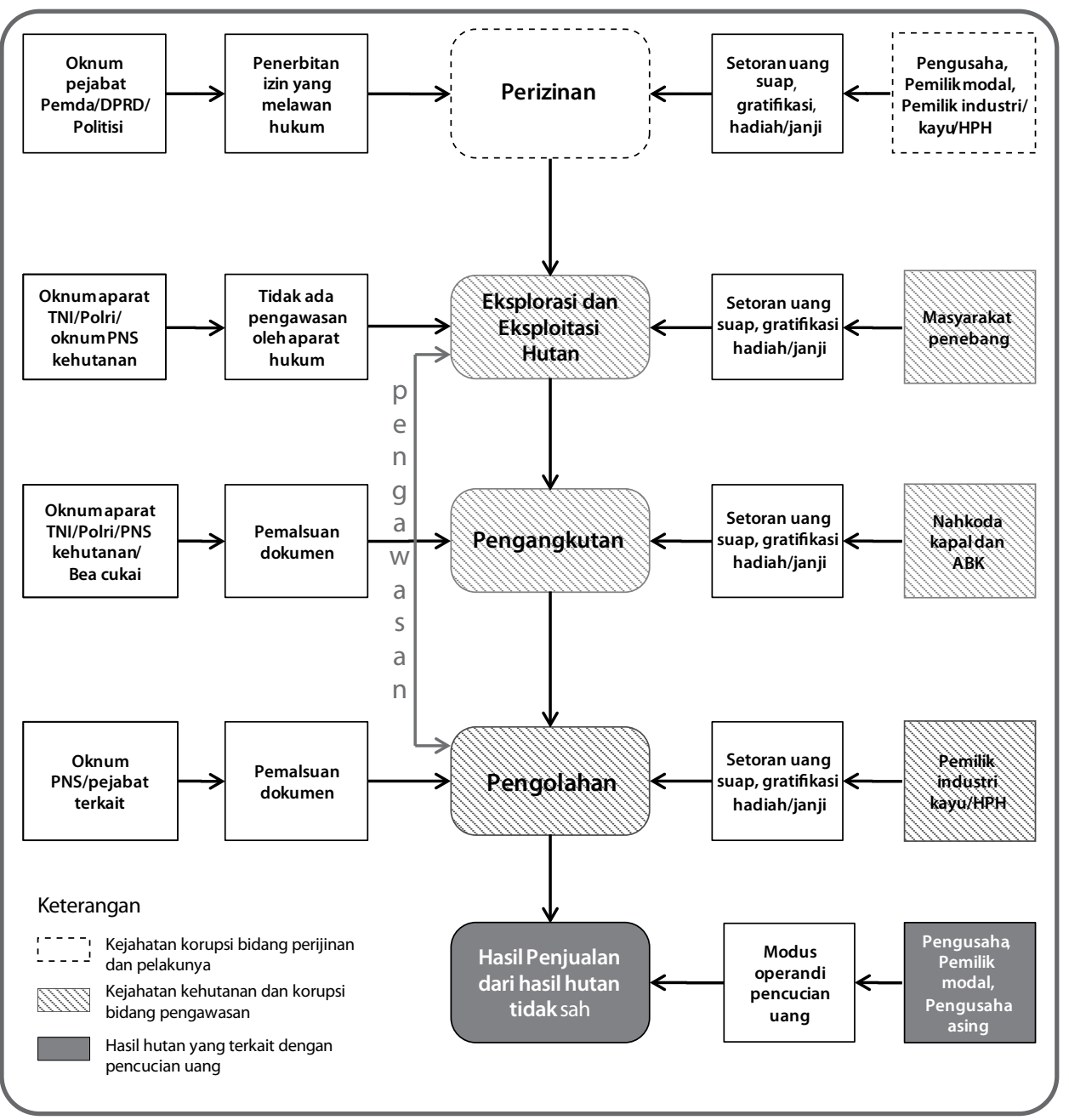

\section{Gambar 7. Alur Kejahatan Bidang Kehutanan dengan Pendekatan Tindak Pidana Korupsi dan Tindak Pidana Pencucian Uang (Berdasarkan Pelaku dan Modus Operandi)}

Skema Gambar 7 di atas menggambarkan bahwa dalam proses kejahatan bidang kehutanan dapat terjadi pula tindak pidana lain didalamnya. Tindak pidana ini meliputi korupsi dan pencucian uang yang telah terindikasi mulai dari proses penerbitan perizinan untuk sektor usaha kehutanan oleh pejabat pemerintah. Termasuk dalam proses ini yaitu dikeluarkannya kebijakan bidang legislasi yang melegitimasi penebangan hutan secara melawan hukum oleh oknum DPRD. 
Dugaan terjadinya tindak pidana korupsi sudah dapat dilihat mulai dari bagian perizinan hingga proses pengolahan hasil hutan yaitu dalam bentuk menerima atau memberikan uang suap, memberikan hadiah, janji serta gratifikasi kepada pejabat atau aparat yang berwenang. Pelaku berbagai bentuk tindak pidana ini bisa berbeda. Misalnya, dalam proses perizinan pelakunya adalah pemilik industri/ $\mathrm{HPH}$, dan dalam proses pengangkutan dilakukan oleh nahkoda kapal di lapangan. Sementara itu dugaan terjadinya tindak pidana pencucian uang, ditandai dengan aliran dana berupa uang suap ke rekening pejabat berwenang yang melakukan penyimpangan.

Demikian pula dalam proses pengawasan penebangan hutan yang dilakukan oleh aparat penegak hukum. Modus operandi tindak pidana korupsinya dapat dilihat dari akibat uang suap, pemberian hadiah, janji serta gratifikasi oleh pihak yang berkepentingan, yang membuat aparat penegak hukum tidak melakukan pengawasan yang semestinya terhadap aktivitas penebangan pohon. Jika selanjutnya dapat dibuktikan adanya uang suap yang masuk ke rekening aparat tersebut sebagai akibat melakukan sesuatu atau tidak melakukan sesuatu yang bertentangan dengan jabatannya, maka patut diduga adanya praktik pencucian uang.

Terakhir, tindak pidana pencucian uang bisa berlangsung setelah hasil hutan yang didapat secara tidak sah tersebut diolah dan berubah bentuk menjadi uang dalam rekening. Tindak pidana ini tetap terjadi walaupun aliran uang hasil kejahatan bidang kehutanan yang masuk ke dalam rekening para pengusaha, pemilik modal maupun pengusaha asing tersebut kemudian digunakan untuk aktivitas yang sah secara hukum.

Bab ini telah menjelaskan cara-cara berlangsungnya kejahatan korupsi dan pencucian uang, memaparkan tipologi dan unsur-unsur serta penjelasan atas unsur-unsurnya dalam kaitannya dengan kegiatan kejahatan kehutanan, khususnya pembalakan liar.

Dengan membaca bab ini diharapkan para penegak hukum dapat melihat lebih luas dengan cara pandang baru bahwa kejahatan di bidang kehutanan, khususnya pembalakan liar sangat mungkin berkaitan dengan kejahatan lainnya, khususnya korupsi dan pencucian uang. Dengan pemahaman baru ini diharapkan upaya penegakan hukum baru yang lebih komprehensif dan mampu menanggulangi modus operandi dan praktik-praktik para pelaku yang menggunakan berbagai jalan untuk dapat menguras kekayaan hutan Indonesia.

Bab 5 akan membahas proses atau hukum acaranya, baik mengenai lembaga-lembaga yang berwenang maupun mengenai tahapan-tahapan dalam hukum acara pidananya. 


\section{Proses Penanganan Perkara}

Untuk melakukan penanganan perkara terhadap dugaan tindak pidana kehutanan dengan pendekatan model ILEA penegak hukum perlu memahami unsur-unsur apa saja yang perlu dipenuhi ketika menggunakan UU Pemberantasan Tindak Pidana Korupsi dan UU Pencegahan dan Pemberantasan TPPU. Selain itu, penegak hukum juga perlu memahami peranan lembaga penegak hukum yang berwenang untuk menangani perkara, prosedur hukum acara serta penerapan pasal terhadap perkara-perkara yang sudah pernah diputuskan oleh pengadilan. Bab ini akan menguraikan aspek hukum acaranya, dari penyidikan hingga pembuktiannya.

\subsection{Peranan Lembaga Penegak Hukum}

Bagian ini menguraikan sejumlah lembaga penegak hukum yang berperan dan mempunyai kewenangan untuk menangani perkara kehutanan dengan pendekatan tindak pidana korupsi dan tindak pidana pencucian uang. Uraian ini mencakup tugas-tugas dan kewenangan lembaga penegak hukum masing-masing pada saat menangani perkara.

\subsubsection{Penyidik, Penuntut Umum dan Hakim dalam UU Kehutanan}

Berdasarkan Pasal 77 UU Kehutanan, lembaga yang berwenang sebagai penyidik untuk menangani kejahatan kehutanan adalah:

1. Pejabat penyidik Kepolisian Negara Republik Indonesia, dengan kewenangan berdasarkan KUHAP

2. Pejabat Pegawai Negeri Sipil tertentu yang lingkup tugas dan tanggung jawabnya meliputi pengelolaan hutan, dengan kewenangan sebagaimana diatur dalam KUHAP, yang kekhususannya diatur pula dalam Pasal 77 ayat (2) yaitu untuk:

a. Melakukan pemeriksaan atas kebenaran laporan atau keterangan yang berkenaan dengan tindak pidana yang menyangkut hutan, kawasan hutan, dan hasil hutan;

b. Melakukan pemeriksaan terhadap orang yang diduga melakukan tindak pidana yang menyangkut hutan, kawasan hutan, dan hasil hutan;

c. Memeriksa tanda pengenal seseorang yang berada dalam kawasan hutan atau wilayah hukumnya; 
d. Melakukan penggeledahan dan penyitaan barang bukti tindak pidana yang menyangkut hutan, kawasan hutan, dan hasil hutan sesuai dengan ketentuan peraturan perundang-undangan yang berlaku;

e. Meminta keterangan dan barang bukti dari orang atau badan hukum sehubungan dengan tindak pidana yang menyangkut hutan, kawasan hutan, dan hasil hutan;

f. Menangkap dan menahan, dalam koordinasi dan pengawasan penyidik Kepolisian Negara Republik Indonesia, sesuai Kitab Undang-undang Hukum Acara Pidana;

g. Membuat dan menandatangani berita acara;

h. Menghentikan penyidikan apabila tidak terdapat cukup bukti tentang adanya tindak pidana yang menyangkut hutan, kawasan hutan, dan hasil hutan.

Selanjutnya, lembaga yang berperan dan memiliki kewenangan sebagai penuntut umum adalah Kejaksaan sebagaimana diamanatkan dalam Pasal 77 ayat (3). Kewenangan jaksa penuntut umum dalam menangani perkara kehutanan dilaksanakan sesuai dengan ketentuan-ketentuan KUHAP.

Berdasarkan Pasal 74 dan Pasal 76 UU Kehutanan, hakim di pengadilan umum (sesuai locus delicti) berperan untuk menyelesaikan sengketa kehutanan dan memeriksa kejahatan kehutanan yang didakwakan oleh jaksa penuntut umum. Tugas dan kewenangan hakim dilaksanakan sesuai dengan ketentuan dalam KUHAP.

Penyelesaian sengketa kehutanan melalui pengadilan dimaksudkan untuk memperoleh putusan mengenai pengembalian suatu hak, besarnya ganti rugi, dan atau tindakan tertentu yang harus dilakukan oleh pihak yang kalah dalam sengketa. Selain itu, pengadilan dapat menetapkan pembayaran uang paksa atas keterlambatan pelaksanaan tindakan tertentu tersebut setiap hari.

\subsubsection{Penyidik, Penuntut Umum dan Hakim dalam UU Pemberantasan Tindak Pidana Korupsi}

Berdasarkan Pasal 11 UU No. 30 Tahun 2002 tentang Komisi Pemberantasan Tindak Pidana Korupsi, KPK baru dapat melakukan penyelidikan, penyidikan, dan penuntutan terhadap suatu tindak pidana korupsi apabila:

a. Melibatkan aparat penegak hukum, penyelenggara negara, dan orang lain yang ada kaitannya dengan tindak pidana korupsi yang dilakukan oleh aparat penegak hukum atau penyelenggara negara;

b. Mendapat perhatian yang meresahkan masyarakat; dan/atau

c. Menyangkut kerugian negara paling sedikit Rp. 1.000.000.000 (satu miliar rupiah).

Dengan demikian jika persyaratan penanganan tindak pidana korupsi oleh KPK di atas tidak dipenuhi, maka penyidikan dilakukan pejabat penyidik Kepolisian Negara Republik Indonesia, dan penuntutan dilakukan oleh kejaksaan. Berkas dakwaan jaksa ini kemudian diajukan untuk diperiksa oleh hakim di pengadilan umum. Tugas serta kewenangan penyidik Polri, jaksa penuntut umum serta hakim di pengadilan umum dalam tindak pidana korupsi ini dilaksanakan sesuai dengan ketentuan dalam KUHAP. 
Sementara itu pelaksanaan tugas penyelidikan, penyidikan, dan penuntutan oleh penyelidik, penyidik dan penuntut dalam KKP Korupsi diberikan dengan kewenangan khusus yang diatur dalam Pasal 12 UU No. 30 Tahun 2002 tentang Komisi Pemberantasan Tindak Pidana Korupsi, yaitu:

a. Melakukan penyadapan dan merekam pembicaraan;

b. Memerintahkan kepada instansi yang terkait untuk melarang seseorang bepergian ke luar negeri;

c. Meminta keterangan kepada bank atau lembaga keuangan lainnya tentang keadaan keuangan tersangka atau terdakwa yang sedang diperiksa;

d. Memerintahkan kepada bank atau lembaga keuangan lainnya untuk memblokir rekening yang diduga hasil dari korupsi milik tersangka, terdakwa, atau pihak lain yang terkait;

e. Memerintahkan kepada pimpinan atau atasan tersangka untuk memberhentikan sementara tersangka dari jabatannya;

f. Meminta data kekayaan dan data perpajakan tersangka atau terdakwa kepada instansi yang terkait;

g. Menghentikan sementara suatu transaksi keuangan, transaksi perdagangan, dan perjanjian lainnya atau pencabutan sementara perizinan, lisensi serta konsesi yang dilakukan atau dimiliki oleh tersangka atau terdakwa yang diduga berdasarkan bukti awal yang cukup ada hubungannya dengan tindak pidana korupsi yang sedang diperiksa;

h. Meminta bantuan interpol Indonesia atau instansi penegak hukum negara lain untuk melakukan pencarian, penangkapan, dan penyitaan barang bukti di luar negeri;

i. Meminta bantuan kepolisian atau instansi lain yang terkait untuk melakukan penangkapan, penahanan, penggeledahan, dan penyitaan dalam perkara tindak pidana korupsi yang sedang ditangani.

\subsubsection{Penyidik, Penuntut Umum dan Hakim dalam UU Pencegahan dan Pemberantasan Tindak Pidana Pencucian Uang}

Penyidik, penuntut dan hakim dalam penanganan tindak pidana pencucian uang didasarkan pada KUHAP, dengan kekhususan kewenangan yang diatur dalam UU TPPU. Selain lembaga penegak hukum di atas, terdapat pula PPATK sebagai lembaga independen yang dibentuk dalam rangka mencegah dan memberantas tindak pidana pencucian uang.

Berdasarkan Pasal 40 UU PPTPPU, dalam melaksanakan tugas PPATK mempunyai fungsi:

a. pencegahan dan pemberantasan tindak pidana Pencucian Uang;

b. pengelolaan data dan informasi yang diperoleh PPATK;

c. pengawasan terhadap kepatuhan Pihak Pelapor; dan

d. analisis atau pemeriksaan laporan dan informasi Transaksi Keuangan yang berindikasi tindak pidana Pencucian Uang dan/atau tindak pidana lain sebagaimana dimaksud dalam Pasal 2 ayat (1). 
Wewenang PPATK dalam melaksanakan fungsi pencegahan dan pemberantasan tindak pidana Pencucian Uang, sebagaimana diatur dalam Pasal 41 yaitu:

a. meminta dan mendapatkan data dan informasi dari instansi pemerintah dan/ atau lembaga swasta yang memiliki kewenangan mengelola data dan informasi, termasuk dari instansi pemerintah dan/atau lembaga swasta yang menerima laporan dari profesi tertentu;

b. menetapkan pedoman identifikasi Transaksi Keuangan Mencurigakan;

c. mengkoordinasikan upaya pencegahan tindak pidana Pencucian Uang dengan instansi terkait;

d. memberikan rekomendasi kepada pemerintah mengenai upaya pencegahan tindak pidana Pencucian Uang;

e. mewakili pemerintah Republik Indonesia dalam organisasi dan forum internasional yang berkaitan dengan pencegahan dan pemberantasan tindak pidana Pencucian Uang;

f. menyelenggarakan program pendidikan dan pelatihan antipencucian uang; dan

g. menyelenggarakan sosialisasi pencegahan dan pemberantasan tindak pidana Pencucian Uang.

Menurut Pasal 42 dalam melaksanakan fungsi pengelolaan data dan informasi PPATK juga berwenang menyelenggarakan sistem informasi.

Selain itu dalam rangka melaksanakan fungsi pengawasan terhadap kepatuhan Pihak Pelapor, Pasal 43 mengatur kewenangan PPATK sebagai berikut:

a. menetapkan ketentuan dan pedoman tata cara pelaporan bagi Pihak Pelapor;

b. menetapkan kategori Pengguna Jasa yang berpotensi melakukan tindak pidana Pencucian Uang;

c. melakukan audit kepatuhan atau audit khusus;

d. menyampaikan informasi dari hasil audit kepada lembaga yang berwenang melakukan pengawasan terhadap Pihak Pelapor;

e. memberikan peringatan kepada Pihak Pelapor yang melanggar kewajiban pelaporan;

f. merekomendasikan kepada lembaga yang berwenang mencabut izin usaha Pihak Pelapor; dan

g. menetapkan ketentuan pelaksanaan prinsip mengenali Pengguna Jasa bagi Pihak Pelapor yang tidak memiliki Lembaga Pengawas dan Pengatur.

Terakhir, sebagaimana diatur Pasal 44, dalam rangka melaksanakan fungsi analisis atau pemeriksaan laporan dan informasi PPATK dapat:

a. meminta dan menerima laporan dan informasi dari Pihak Pelapor;

b. meminta informasi kepada instansi atau pihak terkait;

c. meminta informasi kepada Pihak Pelapor berdasarkan pengembangan hasil analisis PPATK;

d. meminta informasi kepada Pihak Pelapor berdasarkan permintaan dari instansi penegak hukum atau mitra kerja di luar negeri;

e. meneruskan informasi dan/atau hasil analisis kepada instansi peminta, baik di dalam maupun di luar negeri; 
f. menerima laporan dan/atau informasi dari masyarakat mengenai adanya dugaan tindak pidana Pencucian Uang;

g. meminta keterangan kepada Pihak Pelapor dan pihak lain yang terkait dengan dugaan tindak pidana Pencucian Uang;

h. merekomendasikan kepada instansi penegak hukum mengenai pentingnya melakukan intersepsi atau penyadapan atas informasi elektronik dan/atau dokumen elektronik sesuai dengan ketentuan peraturan perundang-undangan;

i. meminta penyedia jasa keuangan untuk menghentikan sementara seluruh atau sebagian Transaksi yang diketahui atau dicurigai merupakan hasil tindak pidana;

j. meminta informasi perkembangan penyelidikan dan penyidikan yang dilakukan oleh penyidik tindak pidana asal dan tindak pidana Pencucian Uang;

k. mengadakan kegiatan administratif lain dalam lingkup tugas dan tanggung jawab sesuai dengan ketentuan Undang-Undang ini; dan

1. meneruskan hasil analisis atau pemeriksaan kepada penyidik.

Dalam melaksanakan kewenangannya, Pasal 45 menyatakan bahwa terhadap PPATK tidak berlaku ketentuan peraturan perundang-undangan dan kode etik yang mengatur mengenai kerahasiaan.

\subsection{Prosedur Hukum Acara}

Bagian ini akan menguraikan proses-proses yang terlibat dalam tingkat penyidikan, penuntutan hingga pengadilan suatu perkara. Hal-hal yang ditekankan mencakup pembuktian, alat bukti, surat dakwaan dan hal-hal khusus lainnya yang diatur dalam masing-masing UU Kehutanan, UU Pemberantasan Tindak Pidana Korupsi dan UU Pencegahan dan Pemberantasan TPPU.

\subsubsection{Secara Umum Menurut KUHAP}

Prosedur hukum acara dalam sistem peradilan pidana diatur dalam KUHAP dengan pokok-pokok sebagai berikut:

\section{a. Penyidikan}

Penyidik adalah pejabat Polri atau pejabat pegawai negeri sipil tertentu yang diberi wewenang khusus oleh undang-undang untuk melakukan penyidikan.

Kewenangan penyidik menurut Pasal 7 ayat (1) KUHAP yaitu:

1. Menerima laporan atau pengaduan dari seorang tentang adanya tindak pidana; (Pasal 7 KUHAP)

2. Melakukan tindakan pertama pada saat di tempat kejadian; (Pasal 7 KUHAP)

3. Menyuruh berhenti seorang tersangka dan memeriksa tanda pengenal diri tersangka; (Pasal 7 KUHAP)

4. Melakukan penangkapan, penahanan, penggeledahan dan penyitaan; (Pasal 7 jo Pasal 131 KUHAP)

5. Melakukan pemeriksaan dan penyitaan surat; [Pasal 7 jo Pasal 132 ayat (2),(3),(4),(5) KUHAP]

6. Mengambil sidik jari dan memotret seorang; (Pasal 7 KUHAP) 
7. Memanggil orang untuk didengar dan diperiksa sebagai tersangka atau saksi; (Pasal 7 KUHAP)

8. Mendatangkan orang ahli yang diperlukan dalam hubungannya dengan pemeriksaan perkara; [Pasal 7 jo Pasal 132 ayat (1) jo Pasal 133 ayat (1) KUHAP]

9. Mengadakan penghentian penyidikan; (Pasal 7 KUHAP)

10. Mengadakan tindakan lain menurut hukum yang bertanggung jawab.

Penyidikan adalah serangkaian tindakan penyidik dalam hal dan menurut cara yang diatur dalam undang-undang ini untuk mencari serta mengumpulkan bukti. Bukti ini kemudian dijadikan dasar untuk menjelaskan tindak pidana yang terjadi dan guna menemukan tersangkanya. Selanjutnya Penyidik menyerahkan berkas perkara kepada penuntut umum. [Pasal 8 ayat (2) KUHAP].

\section{b. Penuntutan dan Surat Dakwaan}

Setelah pengumpulan bukti diselesaikan dalam proses penyidikan, dan perkara dapat dilanjutkan karena dianggap telah cukup bukti, maka proses selanjutnya adalah penuntutan. Bagian yang sangat penting dan benar-benar harus mendapat perhatian oleh Jaksa yaitu perumusan tindak pidana yang didakwakan kepada terdakwa, yang disimpulkan dan ditarik dari hasil pemeriksaan penyidikan, dalam bentuk surat dakwaan. Karena itu perumusan surat dakwaan harus konsisten dan sinkron dengan hasil pemeriksaan penyidikan karena surat dakwaan merupakan landasan bagi hakim dalam pemeriksaan di muka sidang pengadilan untuk melihat ada atau tidaknya kesalahan terdakwa.

Berdasarkan Pasal $143 \mathrm{KUHAP}^{17}$, surat dakwaan harus memenuhi syarat sebagai berikut (Harahap 1988):

a. Syarat formil, memuat hal-hal yang berhubungan dengan:

- Surat dakwaan diberi tanggal dan ditandatangani oleh penuntut umum/jaksa,

- Nama lengkap, tempat lahir, umur atau tanggal lahir, jenis kelamin, kebangsaan, tempat tinggal, agama dan pekerjaan tersangka.

b. Syarat materil, memuat dua unsur yang tidak boleh dilalaikan:

- Uraian cermat, jelas dan lengkap mengenai tindak pidana yang didakwakan,

- Dengan menyebutkan waktu dan tempat tindak pidana itu dilakukan.

17 Pasal 143 KUHAP

(1) Penuntut umum melimpahkan perkara ke pengadilan negeri dengan permintaan agar segera mengadili perkara tersebut disertai dengan surat dakwaan.

(2) Penuntut umum membuat surat dakwaan yang diberi tanggal dan ditandatangani serta berisi:

a. nama lengkap, tempat lahir, umur atau tanggal lahir, jenis kelamin, kebangsaan, tempat tinggal, agama dan pekerjaan tersangka;

b. uraian secara cermat, jelas dan lengkap mengenai tindak pidana yang didakwakan dengan menyebutkan waktu dan tempat tindak pidana itu dilakukan.

(3) Surat dakwaan yang tidak memenuhi ketentuan sebagaimana dimaksud dalam ayat (2) huruf b batal demi hukum.

(4) Turunan surat pelimpahan perkara beserta surat dakwaan disampaikan kepada tersangka atau kuasanya atau penasihat hukumnya dan penyidik, pada saat yang bersamaan dengan penyampaian surat pelimpahan perkara tersebut ke pengadilan negeri.

61 M. Yahya Harahap, Pembahasan Permasalahan dan Penerapan KUHAP Jilid I, Jakarta: Pustaka Kartini, 1988, hal. 420. 
Suatu surat dakwaan dapat dianggap tidak memenuhi syarat materil apabila terdapat hal-hal berikut (Harahap 1988):

- Surat dakwaan tidak lengkap, yaitu apabila unsur-unsur tindak pidana yang didakwakan tidak dijelaskan secara keseluruhan/lengkap atau susunan kumulasinya maupun perumusannya tidak jelas antara dakwaan yang satu dengan yang lain.

- Surat dakwaan yang berisi pertentangan antara yang satu dengan yang lain sehingga menimbulkan 'keraguan' bagi terdakwa tentang perbuatan atau tindakan mana yang didakwakan kepadanya.

Bentuk surat dakwaan secara (Harahap 1988) umum adalah:

a. Surat dakwaan biasa yaitu disusun dalam rumusan 'tunggal' atau hanya berisi satu dakwaan saja. Surat ini dapat diberlakukan dalam tindak pidana yang jelas dan tidak mengandung faktor penyertaan, 'perbarengan' (concursus), alternatif maupun subsider. Karena itu baik pelaku maupun tindak pidana yang dilakukan sifatnya sangat jelas dan sederhana, dan surat dakwaan sudah memadai dirumuskan dalam bentuk tunggal.

b. Surat dakwaan alternatif yaitu antara dakwaan yang satu dengan yang lain saling 'mengecualikan' dan memberi 'pilihan' kepada hakim atau pengadilan untuk menentukan dakwaan mana yang tepat ditujukan kepada terdakwa sehubungan dengan tindak pidana yang dilakukannya. Surat dakwaan jenis ini ditujukan untuk menghindari pelaku tindak pidana terlepas dari pertanggungjawaban hukum, dan memberi pilihan kepada hakim untuk menerapkan hukum yang lebih tepat. Surat dakwaan alternatif umumnya baru dapat diterapkan apabila tindak pidana yang dilakukan terdakwa berada dalam persentuhan dua atau beberapa pasal tindak pidana yang saling berdekatan corak dan ciri kejahatannya. Namun peristiwa pidananya sendiri tidak sampai menimbulkan titik sentuh 'perbarengan' (concursus idealis atau concursus realis).

c. Surat dakwaan subsider/pengganti yaitu terdiri dari dua atau beberapa dakwaan yang disusun dan dijejerkan secara berturut-turut, mulai dari dakwaan tindak pidana yang terberat sampai ke dakwaan tindak pidana yang teringan. Dakwaan kedua (subsider) sifatnya adalah pengganti dari dakwaan pertama (primer). Bentuk dakwaan subsider umumnya digunakan apabila peristiwa tindak pidana yang terjadi itu menimbulkan suatu akibat, dan akibat ini meliputi/bersinggungan dengan beberapa ketentuan pasal pidana yang hampir saling berdekatan cara melakukan tindak pidananya.

d. Surat dakwaan kumulatif yaitu rangkaian beberapa dakwaan atau gabungan dari beberapa dakwaan sekaligus. Surat dakwaan ini dimungkinkan oleh adanya:

1. Beberapa tindak pidana yang dilakukan oleh orang yang sama dan kepentingan pemeriksaan tidak menjadikan halangan untuk penggabungan

2. Beberapa tindak pidana yang bersangkut-paut satu dengan yang lain, yaitu apabila tindak pidana tersebut dilakukan oleh:

- lebih dari satu orang yang bekerja sama dan dilakukan pada saat yang bersamaan

- lebih dari satu orang pada saat dan tempat yang berbeda tetapi 
merupakan pelaksanaan dari mufakat jahat yang dibuat oleh mereka sebelumnya

- satu orang atau lebih dengan maksud mendapatkan alat yang akan digunakan untuk melakukan tindak pidana lain atau menghindarkan diri dari pemidanaan karena suatu tindak pidana

3. Beberapa tindak pidana yang tidak bersangkut-paut satu dengan yang lain, tetapi yang satu dengan yang lain itu ada hubungannya; dalam hal ini penggabungan perlu bagi kepentingan pemeriksaan.

\section{c. Pengadilan (Pembuktian dan Alat Bukti)}

Pembuktian diperlukan untuk memenuhi unsur-unsur pasal yang disangkakan/ didakwakan. Berikut ini terdapat beberapa teori pembuktian (Setyono) ${ }^{18}$ yaitu:

1. Sistem pembuktian keyakinan hakim belaka (conviction in time), ditandai dengan hal-hal berikut:

a. Pemidanaan tanpa didasarkan pada alat-alat bukti dalam UU, karena aliran ini didasarkan semata-mata atas keyakinan hakim, tidak terikat dengan aturan-aturan tentang pembuktian, dan menyerahkan segala sesuatu kepada kebijaksanaan sehingga ada anggapan hakim bersifat subyektif.

b. Dalam sistem ini pula hakim dapat menentukan wujud kebenaran dalam sistem pembuktian ini berdasarkan perasaan belaka dalam menentukan apakah keadaan harus dianggap telah terbukti.

c. Keyakinan hakim yang menentukan wujud kebenaran sejati dalam sistem pembuktian ini.

2. Sistem pembuktian menurut undang-undang secara positif, ditandai dengan halhal berikut:

a. Alat-alat bukti sudah dipakai sesuai dengan yang ditetapkan undang-undang sehingga hakim harus menetapkan keadaan sudah terbukti, walaupun ia mungkin berkeyakinan bahwa yang harus dianggap terbukti itu tidak benar

b. Hakim tetap menyatakan terdakwa tidak terbukti, walaupun mungkin ia berkeyakinan bahwa terdakwa itu melakukan tindak pidana.

c. Suatu perbuatan tidak dapat dipidana, kecuali berdasarkan kekuatan ketentuan perundang-undangan pidana yang telah ada sebelumnya [Pasal 1 ayat (1) KUHP].

3. Sistem pembuktian menurut undang-undang secara negatif, ditandai dengan hal-hal berikut:

a. Perpaduan antara sistem pembuktian menurut undang-undang secara positif dan sistem pembuktian keyakinan hakim belaka.

b. Negatief wettelijk stelsel: "salah tidaknya seorang terdakwa ditentukan oleh keyakinan hakim yang didasarkan pada cara dan dengan alat-alat bukti yang sah menurut UU".

4. Sistem pembuktian berdasarkan keyakinan hakim atas alasan yang logis (conviction raisonce) ditandai dengan hal-hal berikut (Harahap 1993): 
a. Keyakinan hakim harus didukung oleh alasan-alasan yang jelas

b. Hakim wajib menguraikan dan menjelaskan alasan-alasan apa yang mendasari keyakinannya atas kesalahan terdakwa

c. Keyakinan hakim harus mempunyai dasar-dasar alasan yang logis dan benarbenar dapat diterima akal.

Berdasarkan Pasal 183 KUHAP, hakim tidak boleh menjatuhkan pidana kepada seorang kecuali apabila berdasarkan sekurang-kurangnya dua alat bukti yang sah ia memperoleh keyakinan bahwa suatu tindak pidana benar-benar terjadi dan bahwa terdakwalah yang bersalah melakukannya. Alat bukti yang dapat diajukan, penyidik dan penuntut umum tetap berpedoman kepada KUHAP Pasal 184 yang mengatur bahwa alat bukti yang sah adalah keterangan saksi, keterangan ahli, surat, petunjuk dan keterangan terdakwa.

Mengenai beban pembuktian dalam proses persidangan, Pasal 66 KUHAP mengatur bahwa terdakwa tidak dibebani kewajiban pembuktian.

\subsubsection{Kekhususan dalam UU Kehutanan}

Dalam UU Kehutanan terdapat tiga kekhususan, yaitu:

- Hukum acara dalam UU Kehutanan didasarkan pada KUHAP. Kekhususannya adalah penyidikan dapat dilakukan oleh PNS Departemen Kehutanan dan Polisi Hutan.

- Surat dakwaan dalam proses penuntutan dapat berupa bentuk tunggal maupun kumulatif.

- Kekhususan dalam pembuktian yaitu dengan menggunakan bukti dari bidang sains untuk diajukan dalam persidangan, selain alat bukti umum yang diatur dalam KUHAP. Bukti-bukti yang dimaksud dalam perkara kehutanan antara lain citra satelit, atau sampel kerusakan hutan yang memerlukan keterangan ahli.

\subsubsection{Kekhususan dalam UU Pemberantasan Tindak Pidana Korupsi, UU Komisi Pemberantasan Korupsi dan UU Pengadilan Tindak Pidana Korupsi}

Dalam UU Pemberantasan Tindak Pidana Korupsi terdapat kekhususan berikut:

- Pasal 38 ayat (1) perkara dapat diperiksa dan diputus tanpa kehadiran terdakwa.

- Pasal 38 ayat (5) dan ayat (6) apabila terdakwa meninggal dunia sebelum ada putusan dan terdapat bukti yang kuat bahwa terdakwa korupsi, barang yang disita dapat dirampas berdasarkan putusan hakim dan tidak dapat dimintakan banding.

- Pasal 40 mengenyampingkan ketentuan UU Peradilan Militer dalam hal adanya tindak pidana korupsi di lingkungan peradilan militer.

Dalam UU KPK terdapat kekhususan berikut:

- Pasal 38 mengabaikan ketentuan Pasal 7 ayat (2) KUHAP mengenai kewenangan penyidik PPNS.

- Pasal 47 mengenai ketentuan yang berlaku mengenai penyitaan dalam peraturan perundang-undangan yang lain tidak berlaku berdasarkan UU ini. 
- Pasal 50 mengenai penyidikan dan penuntutan oleh Polri dan Kejaksaan wajib dilaporkan dan dikoordinasikan dengan KPK apabila telah diberitahukan sebelumnya kepada KPK. Sebaliknya, apabila KPK telah melakukan penyidikan, Polri dan Kejaksaan tidak berwenang lagi untuk melakukan penyidikan.

Dalam UU Pengadilan Tindak Pidana Korupsi terdapat kekhususan berikut:

- Pasal 6 mengenai kewenangan Pengadilan Tindak Pidana Korupsi memeriksa perkara terkait tindak pidana korupsi, tindak pidana pencucian uang yang pidana awalnya adalah tindak pidana korupsi, dan tindak pidana dalam UU lain ditentukan tindak pidana korupsi.

Selain berdasarkan KUHAP, alat bukti dalam sidang tindak pidana korupsi juga diatur dalam Pasal 26 A UU No. 20 Tahun 2001 jo UU No. 31 Tahun 1999 tentang Pemberantasan Tindak Pidana Korupsi.

Khusus untuk tindak pidana korupsi alat bukti yang sah dalam bentuk petunjuk, sebagaimana dimaksud dalam Pasal 188 ayat (2) UU Acara Pidana, juga dapat diperoleh dari:

a. Alat bukti lain berupa informasi yang diucapkan, dikirim, diterima, atau disimpan secara elektronik dengan alat optik atau yang serupa dengan itu; dan

b. Dokumen, yakni setiap rekaman data atau informasi yang dapat dilihat, dibaca, dan atau didengar yang dapat dikeluarkan dengan atau tanpa bantuan suatu sarana, baik yang tertuang di atas kertas, benda fisik apapun selain kertas, maupun yang terekam secara elektronik, yang berupa tulisan, suara, gambar, peta, rancangan, foto, huruf, tanda, angka atau perforasi yang memiliki makna.

\section{Pasal 188}

(2) Petunjuk sebagaimana dimaksud dalam ayat (1) hanya dapat diperoleh dari:

a. Keterangan saksi;

b. Surat;

c. Keterangan terdakwa.

\section{Penjelasan Pasal 26a}

Huruf a

Petunjuk yang 'disimpan secara elektronik' mencakup data yang disimpan dalam mikro film, Compact Disk Read Only Memory (CD-ROM) atau Write Once Read Many (WORM).

Dalam ayat ini yang dimaksud dengan 'alat optik atau yang serupa dengan itu' tidak terbatas pada data penghubung elektronik (electronic data interchange), surat elektronik (e-mail), telegram, teleks, dan faksimili.

Surat dakwaan dalam tindak pidana korupsi umumnya dibuat dalam bentuk alternatif atau subsider. 
Dalam proses pembuktian di persidangan, UU Tindak Pidana Korupsi menganut sistem pembuktian terbalik yang terbatas dan berimbang. Terdakwa dapat membuktikan bahwa ia tidak melakukan tindak pidana korupsi dan apabila terdakwa dapat membuktikannya, tidak berarti ia tidak terbukti melakukan korupsi, sebab Jaksa Penuntut Umum masih wajib untuk membuktikan dakwaannya.

\subsubsection{Kekhususan dalam UU Pencegahan dan Pemberantasan TPPU}

Dalam berbagai pendapat di lapangan terdapat pemahaman bahwa karena TPPU merupakan tindak pidana lanjutan dari tindak pidana awal, maka pemrosesan TPPU perlu dibuktikan terlebih dulu kejahatan asalnya dengan dakwaan kumulatif. Namun dalam kenyataannya, pendapat seperti ini tidak benar karena pada dasarnya TPPU dapat berdiri sendiri berdasarkan ketentuan peraturan perundangundangan yang berlaku serta fakta pengadilan sebagaimana Pasal 69: untuk memulai pemeriksaan tindak pidana pencucian uang, harta kekayaan yang diduga merupakan hasil tindak pidana tidak perlu dibuktikan terlebih dahulu tindak pidana asalnya (Jaksa Agung 2009).

Sejauh ini terdapat kurang lebih 18 perkara yang telah disidangkan tanpa dibuktikan terlebih dulu kejahatan asalnya (Jaksa Agung 2009). Salah satunya adalah perkara tindak pidana pencucian uang atas nama Tonny CM (dakwaan kumulatif) di Pengadilan Negeri Jakarta Selatan dengan No 956/Pid.B/2005/PN.Jak.Sel (Jaksa Agung 2009). Dalam hal ini pembuatan surat dakwaan jaksa penuntut umum yang menangani perkara tindak pidana pencucian uang dapat memilih beberapa bentuk surat dakwaan (Husein 2010) yaitu:

- tindak pidana awal dan pencucian uang dibuat secara alternatif

- tindak pidana awal dan pencucian uang dibuat secara kumulatif

- tindak pidana awal dan pencucian uang dibuat secara terpisah atau tunggal

Contoh kasus dengan dakwaan kumulatif yaitu putusan pengadilan dengan nama terdakwa DC. Terdakwa selaku bendahara sebuah rumah ibadah membuka rekening tanpa pengetahuan pengurus rumah ibadah, dan rekening ini digunakannya untuk menempatkan dana hasil penyalahgunaan wewenang atas kegiatan rekonsiliasi rekening antarkantor. Dalam kasus ini DC didakwa Pasal 2 jo Pasal 18 ayat (1) huruf a dan huruf b, ayat (2) dan ayat (3) UU Pemberantasan Tindak Pidana Korupsi. Selanjutnya dana dalam rekening digunakan untuk kepentingan terdakwa. Karena itu ia didakwa dengan Pasal 3 ayat (1) huruf a dan huruf c UU No 25 Tahun 2003 jo UU No. 15 Tahun 2002 tentang TPPU. ${ }^{19}$

Contoh kasus dengan dakwaan alternatif yaitu putusan pengadilan dengan nama terdakwa AKP alias HM yang didakwa dengan:

- Pasal 3 ayat (1) huruf a atau b UU No 25 Tahun 2003 jo UU No. 15 Tahun 2002 tentang TPPU

- Pasal 378 KUHP jo Pasal 55 ayat (1) ke 1 KUHP jo Pasal 65 ayat (1) KUHP

- Pasal 372 KUHP jo Pasal 65 ayat (1) KUHP

19 Penanganan kasus ini masih menggunakan Undang-undang TPPU yang lama. 
Dalam perkara ini hakim memutus dengan dakwaan pertama tentang pencucian uang.

Contoh kasus dengan dakwaan alternatif subsider yaitu putusan pengadilan dengan nama terdakwa LHPP alias P yang didakwa dengan:

\section{Pertama}

- Primer Pasal 3 ayat (1) huruf a UU No 25 Tahun 2003 jo UU No. 15 Tahun 2002 tentang TPPU

- Subsider Pasal 3 ayat (1) huruf c UU No 25 Tahun 2003 jo UU No. 15 Tahun 2002 tentang TPPU

- Lebih Subsider Pasal 6 ayat (1) huruf c UU No 25 Tahun 2003 jo UU No. 15 Tahun 2002 tentang TPPU

Kedua

- Primer Pasal 263 ayat (1) KUHP jo Pasal 55 ayat (1) ke 1 KUHP

- Subsider Pasal 263 ayat (2) KUHP jo Pasal 55 ayat (1) ke 1 KUHP

Ketiga

- Pasal 378 KUHP jo Pasal 65 ayat (1) KUHP

Selanjutnya selain merujuk kepada KUHAP, penyidik, penuntut umum dan hakim juga harus mengikuti kekhususan dalam UU No 25 Tahun 2003 jo UU No. 15 Tahun 2002 tentang TPPU sebagai berikut ${ }^{71}$ (Undang-undang ini kemudian diubah menjadi UU No. 8 Tahun 2010 tentang Pencegahan dan Pemberantasan TPPU):

- Penyidik, penuntut umum dan hakim berwenang memerintahkan kepada penyedia jasa keuangan untuk melakukan pemblokiran harta kekayaan setiap orang yang telah dilaporkan oleh PPATK kepada penyidik, yaitu tersangka atau terdakwa, yang diketahui atau patut diduga merupakan hasil tindak pidana. Hal yang sama diatur juga dalam Pasal 71 UU No. 8 Tahun 2010. Selain itu dalam Pasal 70 UU No. 8 Tahun 2010 diatur bahwa Penyidik, penuntut umum dan hakim berwenang memerintahkan pihak pelapor untuk melakukan penundaan transaksi terhadap harta kekayaan yang diketahui atau patut diduga merupakan hasil tindak pidana.

- Dalam meminta keterangan kepada Penyedia Jasa Keuangan, ketentuan undangundang yang mengatur tentang rahasia bank dan kerahasiaan transaksi keuangan lainnya tidak berlaku bagi penyidik, penuntut umum dan hakim ketua majelis. Hal yang sama diatur dalam Pasal 72 ayat 2 UU No. 8 Tahun 2010.

- Terdakwa wajib membuktikan bahwa harta kekayaannya bukan merupakan hasil tindak pidana (asas pembuktian terbalik) berdasarkan Pasal 35 UU No 25 Tahun 2003 jo UU No. 15 Tahun 2002 tentang TPPU. Hal yang sama juga diatur dalam Pasal 77 UU No 8 Tahun 2010.

- Dimungkinkan pemeriksaan dan putusan majelis hakim tanpa kehadiran terdakwa [in absentia, Pasal 36 ayat (1),(2),(3) UU No 25 Tahun 2003 jo UU No. 15 Tahun 2002 tentang TPPU, yang diatur juga dalam Pasal 79 ayat 1 UU No 8 Tahun 2010.] 
- Bila terdakwa meninggal dunia sebelum putusan hakim dijatuhkan dan terdapat bukti-bukti yang meyakinkan bahwa yang bersangkutan telah melakukan tindak pidana pencucian uang, maka hakim dapat mengeluarkan ketetapan bahwa harta kekayaan terdakwa yang telah disita dirampas untuk Negara. Ketentuan ini sebelumnya diatur dalam Pasal 37 UU No 25 Tahun 2003 jo UU No. 15 Tahun 2002 tentang TPPU, yang diatur kembali dalam Pasal 79 ayat 4 UU No. 8 Tahun 2010.

Selain itu terdapat pula ketentuan sebagai berikut (PPATK 2009):

- Jika dalam pemeriksaan sidang pengadilan diperoleh cukup bukti terjadinya tindak pidana pencucian uang, hakim memerintahkan penyitaan terhadap harta kekayaan yang patut diduga hasil tindak pidana yang belum disita oleh penyidik atau penuntut umum (Pasal 34 UU No. 25 Tahun 2003 jo UU No. 15 Tahun 2002 tentang TPPU). Hal yang sama diatur Pasal 81 UU No 8 Tahun 2010 bahwa Dalam hal diperoleh bukti yang cukup bahwa masih ada Harta Kekayaan yang belum disita, hakim memerintahkan jaksa penuntut umum untuk melakukan penyitaan Harta Kekayaan tersebut.

- Dalam proses peradilan, nama identitas pelapor wajib dirahasiakan [Pasal 39 ayat (1) UU No 25 Tahun 2003 jo UU No. 15 Tahun 2002 tentang TPPU, yang juga diatur dalam Pasal 83 dan Pasal 85 UU No 8 Tahun 2010).

Dalam pengaturan alat bukti, selain merujuk pada KUHAP, juga merujuk pada Pasal 73 UU No 8 Tahun 2010 bahwa alat bukti pemeriksaan tindak pidana pencucian uang juga berupa:

a. Alat bukti sebagaimana dimaksud dalam Hukum Acara Pidana; dan/atau

b. Alat bukti lain berupa informasi yang diucapkan, dikirimkan, diterima, atau disimpan secara elektronik dengan alat optik atau yang serupa dengan itu; dan

c. Dokumen sebagaimana dimaksud dalam Pasal 1 angka 16 UU No 8 Tahun 2010, yang berbunyi:

Dokumen adalah data, rekaman, atau informasi yang dapat dilihat, dibaca, dan/ atau didengar, yang dapat dikeluarkan dengan atau tanpa bantuan suatu sarana, baik yang tertuang di atas kertas, benda fisik apapun selain kertas, atau yang terekam secara elektronik, termasuk tetapi tidak terbatas pada:

a. Tulisan, suara, atau gambar;

b. Peta, rancangan, foto, atau sejenisnya;

c. Huruf, tanda, angka, simbol, atau perforasi yang memiliki makna atau dapat dipahami oleh orang yang mampu membaca atau memahaminya.

\subsubsection{Penerapan dalam perkara-perkara yang sudah diputus oleh pengadilan}

Berikut ini adalah penerapan pasal tindak pidana korupsi dalam kejahatan kehutanan, ditambah dengan pertimbangan hakim terhadap unsur-unsur pasal terkait pada suatu putusan yang sudah berkekuatan hukum tetap. Unsur-unsur dari pasal terkait tersebut diuraikan dalam Kotak $1-5$. 
Kotak 1. Unsur-Unsur Tindak Pidana Korupsi dalam Pasal 2 UU No. 31 Tahun 1999 jo UU No. 20 Tahun 2001

Setiap orang dalam kejahatan kehutanan ialah masyarakat yang melakukan penebangan pohon di lapangan, pemilik modal (cukong) dan pengusaha, pemilik industri kayu atau pemilik HPH serta oknum pejabat pemerintah dan oknum aparat pemerintah.

Secara melawan hukum dalam praktik unsur ini dibuktikan dengan melihat perbuatan yang dilakukan bertentangan dengan peraturan perundang-undangan yang terkait. Pembuktian adanya tindak pidana korupsi cukup dengan dipenuhinya unsur-unsur perbuatan yang sudah dirumuskan, bukan dengan timbulnya akibat.

Memperkaya diri sendiri atau orang lain atau suatu korporasi dibuktikan dengan menerima uang/imbalan untuk melakukan suatu pekerjaan/perbuatan atau dari perbuatan yang telah dilakukan dan bukti transfer/catatan rekening.

Dapat merugikan keuangan negara dengan melihat apakah ada keterlibatan/ berhubungan dengan kekayaan negara.

Perekonomian negara yang dapat dibuktikan dengan melihat bahwa perbuatan pidananya terkait dengan keuangan negara dan/atau ada kerugian negara, melalui laporan lembaga negara terkait. Dalam kasus kehutanan, pembalakan liar jelas merugikan keuangan negara dari sisi pajak pendapatan negara, termasuk kerugian yang ditimbulkan apabila terjadi kerusakan hutan.

Kotak 2. Unsur-Unsur Tindak Pidana Korupsi dalam Pasal 3 UU No. 31 Tahun 1999 jo UU No. 20 Tahun 2001

Setiap orang dalam kejahatan kehutanan ialah oknum pejabat pemerintah dan oknum aparat pemerintah.

\section{Menguntungkan diri sendiri atau orang lain atau suatu korporasi}

sebagaimana disebutkan dalam Kotak 1.

\section{Menyalahgunakan kewenangan, kesempatan atau sarana yang ada} padanya yaitu dengan melakukan perbuatan yang bertentangan dengan peraturan perundang-undangan.

Karena jabatan atau kedudukan unsur ini dapat dibuktikan dengan SK Pengangkatan, rincian tugas dan kewenangan, serta tanggung jawab pelaku di dalam instansinya. Misalnya, di sektor kehutanan pejabat pemerintah daerah mengeluarkan izin penebangan pohon, padahal tidak sesuai dengan Rencana Karya Tahunan, dan ia menerima imbalan.

Merugikan keuangan negara atau perekonomian negara sebagaimana disebutkan dalam Kotak 1. 
Kotak 3. Unsur-Unsur Tindak Pidana Korupsi dalam Pasal 5 ayat (1) a UU No. 31 Tahun 1999 jo UU No. 20 Tahun 2001

Setiap orang dalam kejahatan kehutanan ialah masyarakat yang melakukan penebangan pohon di lapangan, pemilik modal (cukong) dan pengusaha, serta pemilik industri kayu atau pemilik HPH.

Memberi atau menjanjikan sesuatu dibuktikan dengan transfer rekening, hadiah, hibah dan pengakuan.

Pegawai negeri atau penyelenggara negara dalam kejahatan kehutanan yaitu oknum pejabat pemerintah, oknum anggota DPRD dan oknum aparat hukum. Alat buktinya adalah SK Pengangkatan, dIl.

\section{Dengan maksud supaya pegawai negeri atau penyelenggara negara tersebut berbuat atau tidak berbuat sesuatu dalam jabatannya. Hal yang dapat dibuktikan dengan keterangan saksi, pengakuan tersangka/terdakwa dan barang bukti berupa rekaman, memo, dll.}

Yang bertentangan dengan kewajibannya. Dalam kejahatan kehutanan seperti membuat kebijakan/memberi izin yang bertentangan dengan peraturan mengenai kehutanan dan lingkungan hidup, tidak melakukan fungsi pengawasan dan penyelidikan di lapangan atas dugaan tindak pidana kehutanan. Hal ini dapat dibuktikan dengan surat izin yang dikeluarkan, foto wilayah hutan yang rusak, rekening bank oknum, dll.

Implementasi Pasal 2 di atas, terlihat dalam pertimbangan hakim Mahkamah Agung pada Kasus AL dengan nomor putusan 68 K/PID.SUS/2008 dan Kasus SAF dengan nomor putusan $380 \mathrm{~K} / \mathrm{PID}$.SUS/2007 adalah sebagai berikut:

Setiap orang dibuktikan dengan Terdakwa yang menjabat sebagai Direksi (yakni sebagai Direktur Keuangan/Umum) pada PT. Keang Nam Development Indonesia. Berdasarkan Pasal 1 ayat (4) Undang-Undang No. 1 Tahun 1995 tentang Perseroan Terbatas "Direksi adalah organ perseroan yang bertanggung jawab atas pengurusan perseroan untuk kepentingan dan tujuan perseroan serta mewakili perseroan, baik di dalam maupun di luar Pengadilan sesuai dengan ketentuan anggaran dasar”.

Dalam kasus ini yang dipandang sebagai pelaku tindak pidana yang didakwakan kepada Terdakwa adalah berkaitan dengan tindakan Perseroan dalam menjalankan usahanya sebagai badan hukum atau Korporasi atas nama Keang Nam Development Indonesia, namun Terdakwa AL sebagai organ perseroan harus dipandang sebagai orang yang turut bertanggung jawab dan dapat dihadapkan sebagai pelaku tindak pidana dalam perkara tindak pidana yang dilakukan untuk dan atas nama badan hukum Perseroan (Korporasi). Hal ini sesuai pula dengan bunyi ketentuan Pasal 1 angka 3 UndangUndang No. 31 Tahun 1999 tentang Pemberantasan Tindak Pidana Korupsi yang berbunyi 'setiap orang adalah orang perseorangan atau termasuk korporasi'. 
Kotak 4. Unsur-Unsur Tindak Pidana Pencucian Uang dalam Pasal 3 UU No. 8 Tahun 2010

Setiap orang dalam kejahatan kehutanan dapat ditujukan kepada Pemilik modal (cukong) dan pengusaha, pemilik industri kayu atau pemilik HPH, serta oknum pejabat pemerintah dan oknum aparat hukum yang menerima suap.

Menempatkan Harta Kekayaan yang diketahuinya atau patut diduganya merupakan hasil tindak pidana

Mentransfer uang yang diketahuinya atau patut diduganya merupakan hasil tindak pidana

Mengalihkan Harta Kekayaan yang diketahuinya atau patut diduganya merupakan hasil tindak pidana

Membelanjakan uang yang diketahuinya atau patut diduganya merupakan hasil tindak pidana

Membayarkan Harta Kekayaan yang diketahuinya atau patut diduganya merupakan hasil tindak pidana

Menghibahkan Harta Kekayaan yang diketahuinya atau patut diduganya merupakan hasil tindak pidana

Menitipkan Harta Kekayaan yang diketahuinya atau patut diduganya merupakan hasil tindak pidana

Membawa ke luar negeri Harta Kekayaan yang diketahuinya atau patut diduganya merupakan hasil tindak pidana

Mengubah bentuk Harta Kekayaan yang diketahuinya atau patut diduganya merupakan hasil tindak pidana

Menukarkan Harta Kekayaan yang diketahuinya atau patut diduganya merupakan hasil tindak pidana dengan mata uang atau surat berharga

atau perbuatan lainnya terkait Harta Kekayaan yang diketahuinya atau patut diduganya merupakan hasil tindak pidana

\section{Dengan tujuan menyembunyikan atau menyamarkan asal usul Harta Kekayaan yaitu berasal dari suatu tindak pidana}

Secara melawan hukum yaitu suatu kewajiban atau larangan yang ditetapkan oleh suatu peraturan tertulis dan apabila tidak dilaksanakan maka mengakibatkan suatu tindak pidana. Dalam kasus SAF unsur ini dibuktikan dengan terdakwa yang telah terbukti melakukan perbuatan melawan hukum karena menerbitkan persetujuan sementara dan Surat Keputusan Persetujuan Prinsip pembukaan lahan dan pemanfaatan kayu kepada beberapa perusahaan yang bertentangan dengan Pasal 4 Ayat 2 Keputusan Menteri Kehutanan dan Perkebunan Nomor 107/KPTS-II/1999 tentang izin usaha 
Kotak 5. Unsur-Unsur Tindak Pidana Pencucian Uang dalam Pasal 5 UU No. 8 Tahun 2010

Setiap orang dalam kejahatan kehutanan dapat ditujukan kepada pemilik modal (cukong) dan pengusaha, pemilik industri kayu atau pemilik HPH, serta oknum pejabat pemerintah dan oknum aparat hukum yang menerima suap.

Yang menerima atau menguasai. Hal ini dapat dibuktikan dengan adanya aliran dana, rekening, kuitansi, bukti penyerahan atau bukti kepemilikan

\section{Penempatan; pentransferan; pembayaran; hibah; sumbangan; penitipan; penukaran, atau menggunakan}

Harta Kekayaan yaitu harus dibuktikan dengan adanya benda atau barang

\section{Yang diketahuinya atau patut diduganya merupakan hasil tindak pidana} yaitu harta kekayaan yang terjadi dari suatu perbuatan pidana, tanpa membuktikan perbuatan pidana asalnya, dan kebenaran bahwa hasil itu adalah berasal dari hasil perbuatan pidana (Tb. Irman S. hal. 50)

perkebunan berskala besar di mana satu grup dalam provinsi hanya diberikan 20.000 hektar. Bukti surat yang dikeluarkan oleh terdakwa tersebut diperkuat dengan keterangan saksi-saksi.

\section{Melakukan perbuatan memperkaya diri sendiri atau orang lain atau suatu}

korporasi dibuktikan dengan mendasarkan pada jumlah kerugian yang dihitung oleh ahli dari BPKP akibat pengangkutan kayu yang tidak dilindungi dokumen dan tanpa pembayaran PSDH dan DR. Keuntungan tindakan-tindakan ini merupakan kekayaan negara yang dinikmati oleh Terdakwa dengan mengorbankan kepentingan rakyat banyak. Dalam kasus SAF unsur ini dibuktikan dengan tindakan terdakwa untuk membuka lahan sawit 1 juta hektar adalah tidak salah, tetapi ternyata realisasi tindakan ini telah menyimpang dari aturan yang ada, sehingga menguntungkan orang lain dan merugikan negara.

Dapat merugikan keuangan negara atau perekonomian negara yang dibuktikan dengan perhitungan kerugian keuangan negara oleh BPKP Perwakilan Provinsi Sumatera Utara. Hal yang sama juga berlaku dalam kasus SAF.

Rumusan dalam Pasal 5 ayat (1) b, sama penjelasannya sebagaimana diuraikan dalam Kotak 3. Perbedaannya hanya berdasarkan unsur "berhubungan dengan sesuatu yang bertentangan dengan kewajiban, dilakukan atau tidak dilakukan dalam jabatannya". Unsur ini dapat dibuktikan antara lain dengan melihat aliran dana yang masuk ke rekening, penelusuran aset dan laporan harta kekayaan pejabat.

Melalui pendekatan Model ILEA, penanganan kejahatan di bidang kehutanan juga dapat dilakukan dengan menggunakan UU Pencegahan dan Pemberantasan TPPU, yang unsur-unsur pasalnya diuraikan sebagai berikut: 
Yang dimaksud dengan unsur 'patut diduganya' dalam Pasal 5 adalah suatu kondisi yang memenuhi setidak-tidaknya pengetahuan, keinginan, atau tujuan pada saat terjadinya Transaksi yang diketahuinya yang mengisyaratkan adanya pelanggaran hukum.

Unsur-unsur pasal tindak pidana pencucian uang di atas dapat dilihat dalam putusan hakim Pengadilan Negeri Karawang No 448/PID.B/2008/PN.KRW atas nama AS sebagai berikut:

Bahwa ia didakwa dengan Pasal 3 ayat (1) huruf c UU No 25 Tahun 2003 jo UU No. 15 Tahun 2002 tentang TPPU, yang mengandung unsur-unsur:

1. Setiap orang;

2. Dengan sengaja membayarkan atau membelanjakan harta kekayaan;

3. Yang diketahuinya atau patut diduganya merupakan hasil tindak pidana;

4. Baik perbuatan itu atas namanya sendiri maupun atas nama pihak lain.

Bahwa dalam pertimbangannya, majelis hakim telah menguraikan unsur-unsur pasal tersebut yaitu:

Dengan sengaja membayarkan atau membelanjakan harta kekayaan mengandung pengertian bahwa sesuatu perbuatan yang dilakukan oleh pelakunya harus diketahui, dikehendaki dan disadari akan akibatnya. Karena itu unsur dengan sengaja ini tidak lain untuk menilai niat sebagai unsur subyektif bahwa Terdakwa mengetahui, menghendaki dan menyadari perbuatan yang dilakukan. Selain itu dalam menilai niat sebagai unsur subyektif tetap harus memperhatikan obyektivitas yang berhubungan dengan norma yang terkait dalam masyarakat, sehingga suatu perbuatan dapat dinilai telah dilakukan dengan sengaja karena telah diterima demikian oleh semua orang.

Harta kekayaan menurut Pasal 1 angka 4 UU No 25 Tahun 2003 jo UU No. 15 Tahun 2002 tentang TPPU adalah semua benda bergerak atau benda tidak bergerak, baik yang berwujud maupun yang tidak berwujud.

Diketahuinya atau patut diduganya merupakan hasil tindak pidana harus dilihat dalam konteks Pasal 2 ayat (1) dan ayat (2) UU No 25 Tahun 2003 jo UU No. 15 Tahun 2002 tentang TPPU.

Perbuatan itu atas namanya sendiri maupun atas nama pihak lain_berhubungan dengan unsur yang kedua yaitu membayarkan atau membelanjakan harta kekayaan. Dengan demikian perbuatan ini bisa dilakukan atas namanya sendiri atau dilakukan atas nama pihak lain. 


\subsection{Masalah Khusus: Pengembalian Aset Hasil Kejahatan}

Dewasa ini pemberantasan korupsi difokuskan kepada tiga hal pokok, yaitu: pencegahan, pemberantasan dan pengembalian aset hasil korupsi (Stolen Asset Recovery STAR). Dalam konteks kejahatan pembalakan liar dan korupsi yang terkait pembalakan liar ini masalah pengembalian aset merupakan hal yang penting karena kegagalan pengembalian aset hasil korupsi dapat mengurangi 'makna' pemidanaan terhadap para koruptor. Upaya pengembalian aset tidak mudah dilakukan karena para pelakunya memiliki akses yang sangat luas dan sulit dijangkau dalam menyembunyikan maupun melakukan pencucian uang hasil korupsinya. Masalah ini menjadi lebih rumit karena tempat penyembunyian aset hasil kejahatan umumnya melampaui batas wilayah negara dimana korupsi dilakukan (Pohan dkk. 2008).

Dalam konteks Indonesia, ada beberapa argumen mengenai pentingnya pengaturan pengembalian aset ini, antara lain:

1. Indonesia masih tergolong salah satu negara terkorup di Asia dan di dunia, sehingga banyaknya kekayaan yang dikorupsi tidak saja membutuhkan penuntutan dan penjatuhan sanksi bagi pelaku tetapi juga pengembalian aset;

2. Indonesia telah meratifikasi UNCAC dan pengembalian aset merupakan salah satu prinsip dasarnya;

3. Indonesia telah mengatur Bantuan Hukum Timbal Balik (Mutual Legal Assistance - MLA) dengan asas timbal balik. Dengan demikian jika menginginkan asetnya yang berada di luar negeri, Indonesia juga harus mengatur hal yang sama dengan negara lain.

Mekanisme pengembalian aset sendiri masih lemah dalam upaya pemberantasan korupsi di Indonesia (Pohan dkk. 2008). Hingga saat ini, RUU mengenai pengembalian aset hasil kejahatan masih dalam tahap penyusunan dan diharapkan dapat mendukung upaya pengembalian aset hasil kejahatan di masa depan. Dengan adanya MLA dan beberapa perjanjian dengan negara lainnya, mekanisme pengembalian aset diharapkan dapat lebih diperkuat.

Secara kelembagaan, lembaga yang memiliki fungsi sebagai pusat kewenangan (central authority) untuk hubungan timbal balik adalah Departemen Hukum dan Hak Asasi Manusia (Depkumham). Departemen ini yang memiliki kewenangan dalam menerima dan mengirimkan permohonan bantuan hukuman dari dalam ke luar negeri dan sebaliknya. Beberapa lembaga penegak hukum dan lembaga lainnya bekerja sama dengan pusat kewenangan ini dalam melaksanakan upaya pengembalian aset melalui mekanisme MLA. Lembaga lain ini mencakup Kepolisian, Kejaksaan, KPK, PPATK dan Departemen Luar Negeri. Meski demikian, beberapa lembaga seperti kejaksaan dan KPK terkadang juga langsung berhubungan dengan lembaga mitra mereka di negara lain untuk melakukan kerja sama pengembalian aset maupun meminta informasi mengenai pelaku atau aset kejahatan. 



\section{Penutup}

Pembalakan liar adalah kejahatan multidimensional. Kejahatan ini tidak hanya menyangkut pelanggaran UU Kehutanan semata tetapi juga menyangkut UU Pemberantasan Tindak Pidana Korupsi, UU Pencegahan dan Pemberantasan Tindak Pidana Pencucian Uang, bahkan juga UU Lingkungan Hidup dan UU Kepabeanan. Uraian dalam buku panduan ini terutama difokuskan pada kejahatan di bidang kehutanan, kejahatan korupsi di sektor kehutanan dan kejahatan pencucian uang dari kejahatan kehutanan.

Beberapa hal penting mengenai pendekatan ILEA telah dibahas dalam bab-bab buku panduan ini yang diharapkan dapat memberikan wawasan dan panduan bagi penegakan hukum untuk menanggulangi kejahatan di bidang kehutanan. Pendekatan ILEA lebih komprehensif karena tidak hanya menggunakan UU Kehutanan, tetapi juga menggunakan UU Pemberantasan Tindak Pidana Korupsi, UU Pencegahan dan Pemberantasan Tindak Pidana Pencucian Uang. Penggunaan pendekatan ini diharapkan dapat lebih melindungi sektor kehutanan dan kekayaan alam Indonesia dari berbagai kejahatan yang saling terkait.

Ada beberapa keuntungan memberantas pembalakan liar dengan menggunakan UU Pemberantasan Korupsi. Pertama, pembuktian tindak pidana ini jauh lebih mudah karena dapat menerapkan pasal-pasal dalam undang-undang terkait yang relevan. Kedua, Indonesia telah meratifikasi UNCAC yang merupakan ujung tombak dalam STAR Initiative. Ketiga, negara yang mengesahkan UNCAC berkewajiban untuk melakukan kerja sama internasional dalam memberantas korupsi. Kewajiban bekerja sama ini tentunya sangat bermanfaat untuk membantu ekstradiksi pelaku pembalakan liar yang melibatkan warga negara asing.

Meski demikian, mengingat sifatnya yang singkat dan padat, para pengguna buku panduan ini diharapkan untuk tetap melengkapinya dengan berbagai peraturan perundang-undangan di bidang kehutanan, korupsi dan pencucian uang serta sumbersumber lainnya yang relevan. 
Dengan berbagai keterbatasannya buku panduan ini diharapkan bermanfaat baik bagi penegak hukum maupun pihak-pihak lainnya yang berkaitan dengan penegakan hukum di sektor kehutanan serta pihak-pihak yang menaruh perhatian di bidang ini.

Semua masukan dan kritik membangun dari pengguna buku panduan ini sangat diharapkan untuk memperbaikinya lebih lanjut. Atas bantuan semua pihak yang telah memberikan masukan dan bantuan dalam pembuatan buku panduan ini kami sampaikan terima kasih. 


\section{Daftar Pustaka}

Antasari 2010 Inilah 15 Modus Mafia Kehutanan, 22 April. http://antasari.net/inilah15-modus-mafia-kehutanan [29 Maret 2011].

Badan Pemeriksa Keuangan (BPK) 2008 Tindak Pidana Pencucian Uang. Jaringan Dokumentasi dan Informasi Hukum, BPK, Jakarta. http://www.jdih.bpk.go.id/ informasihukum/MoneyLaundring.pdf [29 Maret 2011].

Eriantono, D. dan Setiono, B. (Tidak diterbitkan) Profil transaksi keuangan bisnis kehutanan: panduan bagi perbankan untuk penerapan prinsip know your customer (KYC) di sektor kehutanan. CIFOR, Bogor, Indonesia.

ESRI (Environmental Systems Research Institute) 1995 Understanding GIS. ESRI, Redlands, CA, USA.

FWI/GFW 2001 Potret Keadaan Hutan Indonesia. Forest Watch Indonesia, Bogor, Indonesia dan Global Forest Watch, Washington, D.C.

Harahap, M.Y. 1988 Pembahasan Permasalahan dan Penerapan KUHAP Jilid I. Pustaka Kartini, Jakarta, Indonesia.

Harahap, M.Y. 1993 Pembahasan Permasalahan dan Penerapan KUHAP Jilid II. Pustaka Kartini, Jakarta, Indonesia.

Husein, Y. 2010 Rezim Anti Pencucian Uang dan Pemberantasan Korupsi di Indonesia. Slide Presentasi disampaikan dalam perkuliahan Pasca Sarjana Fakultas Hukum Universitas Indonesia Kelas KPK. 11 Maret. Jakarta, Indonesia.

Husein, Y. 2007 Bunga Rampai Anti Pencucian Uang. Books Terrace \& Library, Bandung, Indonesia.

Indonesia Corruption Watch (ICW) 2004 Pola Praktik Korupsi dalam Perizinan Konsesi Hutan. ICW, Jakarta, Indonesia.

Indonesia Corruption Watch (ICW) 2009 Korupsi dalam Pemberantasan Illegal Logging: Analisis Kinerja dan Alternative Kerangka Hukum. ICW, Jakarta, Indonesia.

Irman S.Tb. 2007 Praktik Pencucian Uang dalam Teori dan Fakta. MQS Publishing, Bandung, Indonesia.

Kejaksaan Agung RI 2009 Sambutan Pembukaan Jaksa Agung RI pada Acara Workshop tentang Pengungkapan dan Pembuktian Perkara Pidana melalui Penelusuran Hasil Kejahatan, Selasa 9 Juni. 
Kementerian Negara Lingkungan Hidup 2006 Panduan Penghitungan Ganti Kerugian Akibat Pencemaran dan atau Perusakan Lingkungan. Kementerian Negara Lingkungan Hidup, Jakarta, Indonesia.

Kementerian Negara Lingkungan Hidup. 2006 Status Lingkungan Hidup Indonesia tahun 2006. Kementerian Negara Lingkungan Hidup, Jakarta, Indonesia.

Komisi Yudisial Republik Indonesia 2007 Kajian Kehormatan, Keluhuran Martabat dan Perilaku Hakim. Jurnal Yudisial (1)3.

Lamintang, P.A.F. 1984 Dasar-dasar Hukum Pidana di Indonesia. Sinar Baru, Bandung.

Mahkamah Agung 2007 Putusan Pengadilan No. 380 K/PID.SUS/2007. Putusan terhadap H. Suwarna Abdul Fatah.

Mahkamah Agung 2008 Putusan Pengadilan No. 68 K/PID.SUS/2008. Putusan terhadap Adelin Lis.

Nurdjana, IGM., Prasetyo, T. dan Sukardi 2005. Korupsi dan Illegal Logging dalam Sistem Desentralisasi. Pustaka Pelajar, Yogyakarta, Indonesia.

Pengadilan Negeri Jakarta Selatan 2005 Putusan Pengadilan No 956/Pid.B/2005/ PN.Jak.Sel atas nama Toni Chaidir Martawinata.

Pengadilan Negeri Karawang 2008 Putusan Pengadilan No 448/PID.B/2008/PN.KRW atas nama Agi Sugiono bin Oto Sukria.

Pengadilan Tindak Pidana Korupsi 2008 Putusan Pengadilan No. 6/PID/TPK/2008/ PN.JKT.PST atas nama Tengku Azmun Jaafar.

Pohan, A. dkk. 2008 Pengembalian Aset Kejahatan. PUKAT Universitas Gadjah Mada, Yogyakarta, Indonesia.

PPATK 2006 Risalah Rapat Koordinasi Penegakan Hukum Tindak Pidana Pencucian Uang (PPATK, Penegak Hukum, Regulator, Industri Perbankan, Lembaga Keuangan Non Bank, Pasar Modal, Akademisi), Direktorat Hukum dan Regulasi PPATK, Jakarta, Indonesia.

PPATK 2007 RUU tentang Pencegahan dan Pemberantasan Tindak Pidana Pencucian Uang. Dipresentasikan pada pelatihan ELSDA Institute, November. Pusat Pelaporan dan Analisis Transaksi Keuangan (PPATK), Jakarta, Indonesia.

PPATK 2008 Pedoman Identifikasi Produk, Nasabah, Usaha, dan Negara Beresiko Tinggi, bagi Penyedia Jasa Keuangan. Pedoman IV, Pusat Pelaporan dan Analisis Transaksi Keuangan (PPATK). Jakarta, Indonesia.

PPATK 2009 Pedoman Pemberian Informasi Tindak Pidana Pencucian Uang di Bidang Kehutanan dan Konservasi Sumber Daya Alam Hayati. Pusat pelaporan dan Analisis Transaksi Keuangan (PPATK), Jakarta, Indonesia.

PPATK 2010 Ikhtisar Ketentuan Pencegahan Dan Pemberantasan Tindak Pidana Pencucian Uang dan Pendanaan Terorisme. Pusat pelaporan dan Analisis Transaksi Keuangan (PPATK), Jakarta, Indonesia.

Santoso, T. 2009 Buku Panduan Eksaminasi Publik Atas Putusan Pengadilan. Partnership dan ICEL, Jakarta, Indonesia.

Setiono, B. dan Husein, Y. 2005 Fighting forest crime and promoting prudent banking for sustainable forest management: the anti money laundering approach. Occasional Paper 44. CIFOR, Bogor, Indonesia. 
Setyono, Y.A. Hukum Pembuktian Dalam Perkara Pidana. http://staff.ui.ac.id/ internal/131861375/material/HukumPembuktianPidana.ppt [15 Maret 2011].

Suarga, R. 2005 Pemberantasan Illegal Logging Optimisme di Tengah Praktek Premanisme Global. Wana Aksara, Banten, Indonesia.

Sukardi 2009 Penyidikan Tindak Pidana Tertentu Beberapa Ketentuan Pidana di luar KUHP. Restu Agung, Jakarta, Indonesia.

Sunderlin, W.D. dan Resosudarmo, I.A.P. 1996 Rates and Causes of Deforestation in Indonesia : Towards a Resolution of the Ambiguities. CIFOR, Bogor, Indonesia

Tacconi, L., Obidzinky, K. dan Agung, F. 2004 Proses Pembelajaran (Learning Lessons) Promosi Sertifikasi Hutan dan Pengendalian Penebangan Liar di Indonesia. CIFOR, Bogor, Indonesia.

United Nation Office on Drugs and Crime (UNODC) 2003 Dokumen United Nations Convention Against Corruption (UNCAC) http://www.unodc.org/unodc/en/ treaties/CAC/index.html [29 April 2011].

Wiyono, R. 2006 Pembahasan UU Pemberantasan Korupsi. Sinar Grafika, Jakarta, Indonesia.

Yuliastuti, E. 2006 Penegakan Hukum Terhadap Tindak Pidana Perdagangan Kayu Ilegal Dalam Sistem Peradilan Pidana. Tesis. Program Pascasarjana Program studi Ilmu Hukum FHUI, Jakarta, Indonesia. 


\section{Lampiran 1.Peraturan Perundang-undangan}

http://indonesia.go.id/in/produk-hukum/undang-undang.html

\section{Kitab Undang-Undang Hukum Pidana}

Undang-Undang Nomor 8 Tahun 2010 tentang Pencegahan dan Pemberantasan Tindak Pidana Pencucian Uang (Lembaran Negara Republik Indonesia Tahun 2010 Nomor 122, Tambahan Lembaran Negara Republik Indonesia Nomor 5164).

Undang-Undang Nomor 46 Tahun 2009 tentang Pengadilan Tindak Pidana Korupsi (Lembaran Negara Republik Indonesia Tahun 2009 Nomor 155, Tambahan Lembaran Negara Republik Indonesia Nomor 5074).

Undang-Undang Nomor 25 Tahun 2003 tentang Perubahan atas Undang-Undang Nomor 15 Tahun 2002 tentang Tindak Pidana Pencucian Uang (Lembaran Negara Republik Indonesia Tahun 2003 Nomor 108, Tambahan Lembaran Negara Republik Indonesia Nomor 4324).

Undang-Undang Nomor 30 Tahun 2002 tentang Komisi Pemberantasan Tindak Pidana Korupsi (Lembaran Negara Republik Indonesia Tahun 2002 Nomor 137, Tambahan Lembaran Negara Republik Indonesia Nomor 4250).

Undang-Undang Nomor 31 Tahun 1999 tentang Pemberantasan Tindak Pidana Korupsi sebagaimana telah diubah dengan Undang-undang Nomor 20 Tahun 2001 tentang Perubahan Atas Undang-undang Nomor 31 Tahun 1999 tentang Pemberantasan Tindak Pidana Korupsi (Lembaran Negara Republik Indonesia Tahun 2001 Nomor 134, Tambahan Lembaran Negara Republik Indonesia Nomor 4150).

Undang-Undang Nomor 43 Tahun 1999 tentang Pokok-Pokok Kepegawaian, (Lembaran Negara Republik Indonesia Tahun 1999 Nomor 169, Tambahan Lembaran Negara Republik Indonesia Nomor 3890)

Undang-Undang Nomor 41 Tahun 1999 tentang Kehutanan (Lembaran Negara Republik Indonesia Tahun 1999 Nomor 167, Tambahan Lembaran Negara Republik Indonesia Nomor 3288).

Undang-Undang Nomor 28 Tahun 1999 tentang Pemerintahan yang Bersih dari Korupsi, Kolusi dan Nepotisme, (Lembaran Negara Republik Indonesia Tahun 1999 Nomor 75, Tambahan Lembaran Negara Republik Indonesia Nomor 3851)

Undang-Undang Nomor 5 Tahun 1986 tentang Peradilan Tata Usaha Negara. Lembaran Negara Republik Indonesia Tahun 1999 Nomor 77)

Undang-Undang Nomor 8 Tahun 1981 Tentang Kitab Undang-Undang Hukum Acara Pidana (KUHAP) (Lembaran Negara Republik Indonesia Tahun 1981 Nomor 76, Tambahan Lembaran Negara Republik Indonesia Nomor 3209). 

Meningkatnya laju deforestasi secara signifikan selama kurun waktu 1970-an sampai tahun 2000-an berdampak pada semakin tingginya desakan terhadap penegakan hukum kejahatan kehutanan yang lebih efektif dan komprehensif. Umumnya penanganan tindak pidana di bidang kehutanan hanya diproses berdasarkan ketentuan dalam Undang-Undang Kehutanan. Beberapa laporan dan hasil studi menyebutkan bahwa penanganan tersebut kurang efektif dalam menghentikan tindak pidana kehutanan. Untuk itu dibutuhkan suatu pendekatan penanganan tindak pidana yang lebih efektif yang diharapkan mampu menguatkan upaya hukum penanganan kejahatan kehutanan.

Beranjak dari kebutuhan tersebut maka CIFOR melalui studi Integrated Law Enforcement Approach (ILEA) atau Pendekatan Penegakan Hukum Terpadu mendorong pendekatan baru yang terpadu untuk menjerat aktor utama pelaku kejahatan kehutanan. Studi ILEA ini mendorong penggunaan perangkat anti korupsi dan anti pencucian uang untuk penanganan kejahatan kehutanan.

Dalam buku ini, beberapa hal penting mengenai pendekatan ILEA dibahas dengan harapan dapat memberikan wawasan dan panduan bagi penegakan hukum untuk menanggulangi kejahatan di bidang kehutanan. Pembahasan buku ini menitikberatkan pada bagaimana penggunaan UndangUndang Tindak Pidana Korupsi dan Undang-Undang Pencegahan dan Pemberantasan Tindak Pidana Pencucian Uang dapat dilakukan untuk menangani kejahatan di bidang kehutanan.

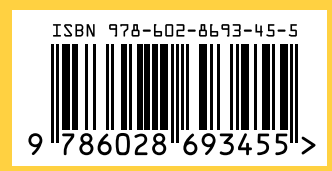

